UNIVERSIDADE DE BRASÍLIA

FACULDADE DE AGRONOMIA E MEDICINA VETERINÁRIA PROGRAMA DE PÓS-GRADUAÇÃo EM AGRONOMIA

USO DO GESSO E SUA INFLUÊNCIA NA PRODUÇÃO DE CANADE-AÇÚCAR, ATRIBUTOS QUÍMICOS E ESTOQUE DE CARBONO NO SOLO DE CERRADO

\author{
LARISSA GOMES ARAÚJO
}

DISSERTAÇÃO DE MESTRADO EM AGRONOMIA

BRASÍLIA/ DF

FEVEREIRO/2015 


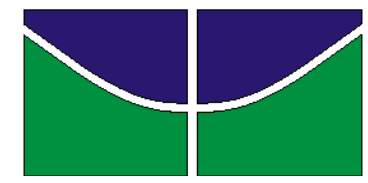

UNIVERSIDADE DE BRASÍLIA

FACULDADE DE AGRONOMIA E MEDICINA VETERINÁRIA PROGRAMA DE PÓS-GRADUAÇÃO EM AGRONOMIA

USO DO GESSO E SUA INFLUÊNCIA NA PRODUÇÃO DE CANADE-AÇÚCAR, ATRIBUTOS QUÍMICOS E ESTOQUE DE CARBONO NO SOLO DE CERRADO

\author{
LARISSA GOMES ARAÚJO \\ ORIENTADOR: CÍCERO CÉLIO DE FIGUEIREDO \\ DISSERTAÇÃO DE MESTRADO EM AGRONOMIA
}

PUBLICAÇÃO: 85/2015

BRASÍLIA/ DF

FEVEREIRO/2015 
UNIVERSIDADE DE BRASÍLIA

FACULDADE DE AGRONOMIA E MEDICINA VETERINÁRIA

PROGRAMA DE PÓS-GRADUAÇÃO EM AGRONOMIA

\title{
USO DO GESSO E SUA INFLUÊNCIA NA PRODUÇÃO DE CANA- DE-AÇÚCAR, ATRIBUTOS QUÍMICOS E ESTOQUE DE CARBONO NO SOLO DE CERRADO
}

\author{
LARISSA GOMES ARAÚJO \\ DISSERTAÇÃO DE MESTRADO SUBMETIDA AO PROGRAMA DE PÓS- \\ GRADUAÇÃO EM AGRONOMIA, COMO PARTE DOS REQUISITOS \\ NECESSÁRIOS À OBTENÇÃO DO GRAU DE MESTRE EM AGRONOMIA.
}

APROVADA POR:

CÍCERO CÉLIO DE FIGUEIREDO - Professor Doutor (Universidade de Brasília) (Orientador) CPF: 029.754.447-02 / Email: cicerocf@unb.br

ALESSANDRA MONTEIRO DE PAULA- Professora Doutora (Universidade de Brasília) (Avaliadora interna) CPF: 820.032.201-78 / Email: alessandramp@unb.br

THOMAZ ADOLPHO REIN - Pesquisador Doutor (Embrapa Cerrados) (Avaliador externo) CPF: 027.990.018-07 / Email: thomaz.rein@embrapa.br BRASÍLIA/DF, 25 de FEVEREIRO de 2015 


\section{FICHA CATALOGRÁFICA}

ARAÚJO, Larissa Gomes

"USO DO GESSO E SUA INFLUÊNCIA NA PRODUÇÃO DE CANA-DEAÇÚCAR, ATRIBUTOS QUÍMICOS E ESTOQUE DE CARBONO NO SOLO DE CERRADO"

Orientação: Cícero Célio de Figueiredo, Brasília, 2015. 101 páginas

Dissertação de Mestrado (M) - Universidade de Brasília / Faculdade de Agronomia e Medicina Veterinária, 2015.

1. Matéria orgânica do solo 2. Carbono particulado 3. Veranicos 4. Sequestro de carbono I. Figueiredo, C.C.de. II. Dro.

\section{REFERÊNCIA BIBLIOGRÁFICA}

ARAÚJO, L.G. Uso do gesso e sua influência na produção de cana-de-açúcar, atributos químicos e estoque de carbono no solo de Cerrado: Faculdade de Agronomia e Medicina Veterinária, Universidade de Brasília, 2015, 101 páginas. Dissertação de Mestrado.

\section{CESSÃO DE DIREITOS}

\section{Nome do Autor: LARISSA GOMES ARAÚJO}

Título da Dissertação de Mestrado: Uso do gesso e sua influência na produção de cana-deaçúcar, atributos químicos e estoque de carbono no solo de Cerrado

Grau: Mestre Ano: 2015.

É concedida à Universidade de Brasília permissão para reproduzir cópias desta dissertação de mestrado para única e exclusivamente propósitos acadêmicos e científicos. $\mathrm{O}$ autor reserva para si os outros direitos autorais de publicação. Nenhuma parte desta dissertação de mestrado pode ser reproduzida sem a autorização por escrito do autor. Citações são estimuladas, desde que citada à fonte.

LARISSA GOMES ARAÚJO

CPF: 035.158.471-46

QNO 15 conj. H casa 16 / CEP: 72.255-608 Ceilândia, DF. Brasil

(61) 9997-6298 / email: lga.agro@gmail.com 
DEDICO,

À toda minha família, especialmente, Aos meus pais:

José Araújo e Anely Gomes 


\section{AGRADECIMENTOS}

Agradeço a Deus por conceder-me a vida e tudo aquilo que a torna esplêndida.

À minha grandiosa família: meus pais, José Araújo de Carvalho e Anely Gomes Araújo, pelo amor dedicado a nossa família; aos meus irmãos Marcos Gomes, Giselly Gomes e ao meu sobrinho Marcus Henrique, por estarem sempre ao meu lado em todos os momentos.

Ao meu noivo e fiel escudeiro, Nédio Rodrigo Tormen, obrigada por sua força para alcançar esse objetivo e todos àqueles que ainda estão por acontecer.

Ao meu orientador, Dr. Cícero Célio de Figueiredo, por sua dedicação ao crescimento de todos os seus orientados, nos fazendo brilhar os olhos durante suas aulas e, mais do que isso, acreditando em nosso potencial. Pelo tempo dedicado às conversas sempre revigoradoras, ensinando que o conhecimento engrandece a vida.

Ao meu co-orientador Me. Djalma Martinhão Gomes de Sousa, pela confiança em mim e por tornar possível a realização desse trabalho. Pelos ensinamentos sobre a ciência do solo e, mais que isso, sobre a vida.

Ao pesquisador Dr. Rafael de Sousa Nunes, por sua dedicação ao meu crescimento acadêmico.

Ao pesquisador Dr. Thomaz Adolfo Rein e à professora Dra. Alessandra, pela presteza em participar da banca e pelas valiosas sugestões apresentadas.

À toda a equipe de campo da Embrapa Cerrados, ao técnico agrícola Valmir Vieira de Sousa, pelo profissionalismo e coordenação de todas as etapas dos trabalhos de campo. Aos operários de campo, José Francisco, Edson Marques, José Ailson, Cláudio Rodrigues e Denis José por toda a ajuda durante os trabalhos de campo.

À equipe dos laboratórios de química, física e microbiologia do solo e análise de plantas, em especial a Diana, Vanessa, Fernanda, Daniella, Josias, Delvico, Vilderete e Lucas, pelo auxílio nas análises de solo e os divertidos encontros.

Aos estagiários da Embrapa Cerrados Josiane e Caio, por sempre estarem dispostos a ajudar nas atividades de laboratório e campo.

Às amigas da UnB, Juliana Sato, Sara Dantas, Isis e Géssica, por todas as conversas e conhecimentos transmitidos.

À Faculdade de Agronomia e Medicina Veterinária da Universidade de Brasília e aos seus professores, coordenadores e funcionários, pelas oportunidades.

À Embrapa Cerrados, por possibilitar a estrutura necessária para a realização deste trabalho.

À Capes, pela concessão da bolsa de estudos.

Por fim, a todos àqueles que contribuíram de alguma forma para a realização deste trabalho, meu muito obrigado. 


\section{SUMÁRIO}

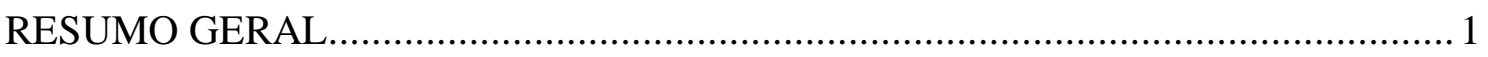

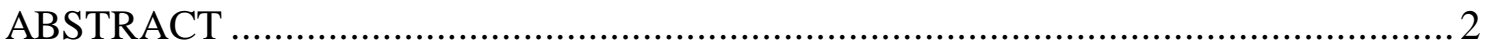

1. INTRODUÇÃO GERAL ............................................................................. 3

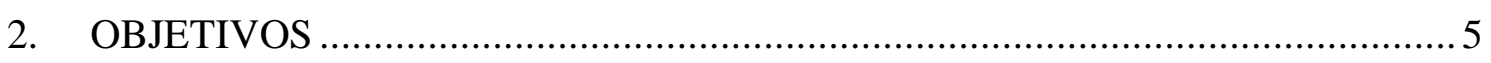

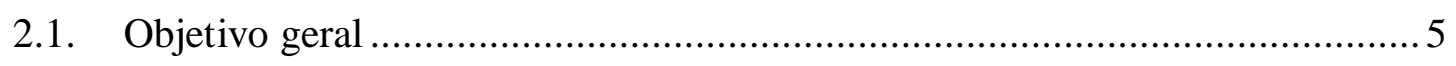

2.2. Objetivos específicos .......................................................................... 5

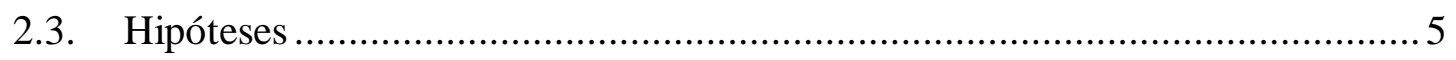

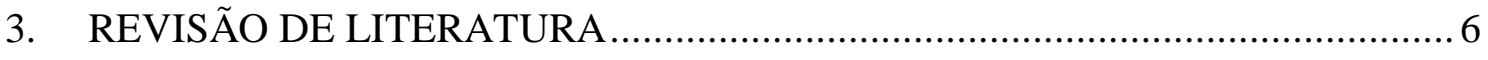

3.1. Agricultura no Cerrado e ocorrência de veranicos ......................................... 6

3.2. Uso do gesso no Cerrado: produção e reações no solo .................................... 7

3.3. Utilização do gesso na agricultura do Cerrado ............................................ 9

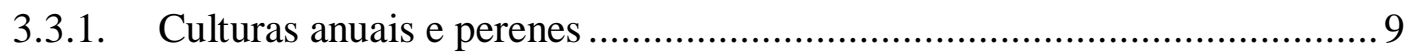

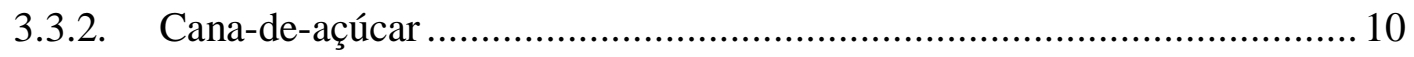

3.4. Matéria orgânica do solo na perspectiva da agricultura de baixa emissão de

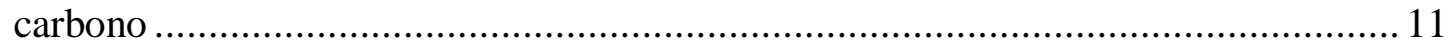

3.4.1. Importância da matéria orgânica do solo ........................................... 11

3.4.2. Fracionamento físico granulométrico da matéria orgânica do solo........... 12

3.4.3. Estoque de carbono no solo e os sistemas agrícolas .............................. 14

3.4.4. Efeito do gesso sobre a matéria orgânica do solo................................. 14

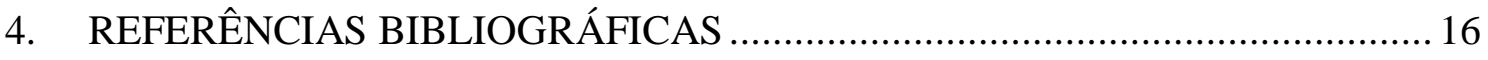

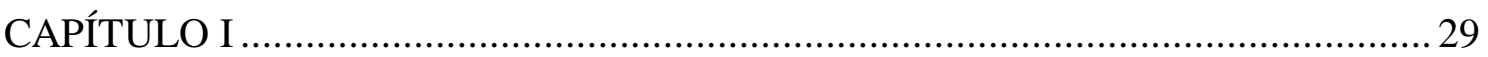

5. USO DE GESSO E SUA INFLUÊNCIA NA PRODUTIVIDADE DE CANA-DEAÇÚCAR E ATRIBUTOS QUÍMICOS DE UM LATOSSOLO VERMELHO DO

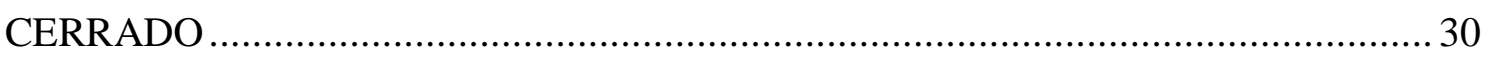

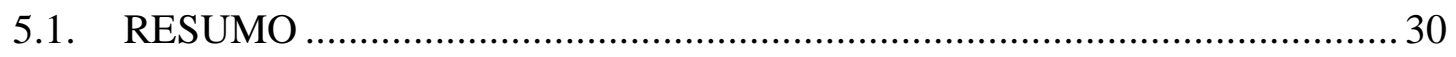


5.2. ABSTRACT .

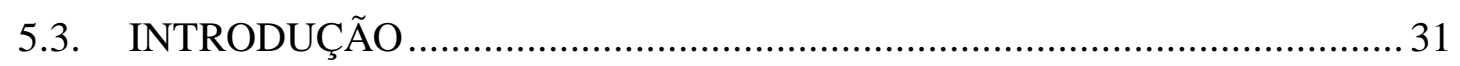

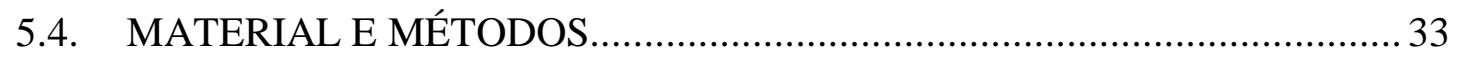

5.4.1. Descrição e manejo da Área Experimental ........................................ 33

5.4.2. Delineamento experimental e definição dos tratamentos ........................ 38

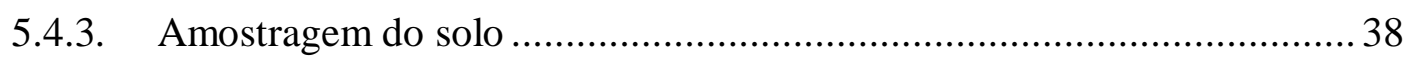

5.4.4. Determinação da produtividade de colmos e qualidade tecnológica.........39

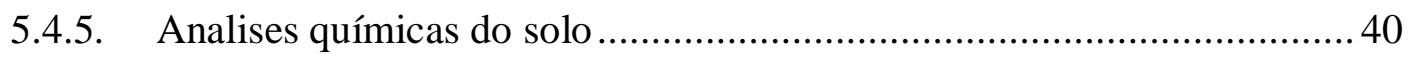

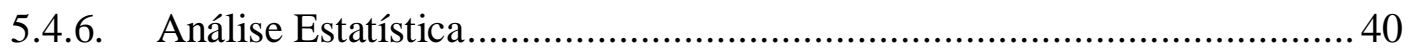

5.5. RESULTADOS E DISCUSSÃO....................................................... 41

5.5.1. Produtividade de colmos e qualidade tecnológica................................ 41

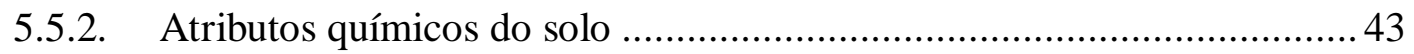

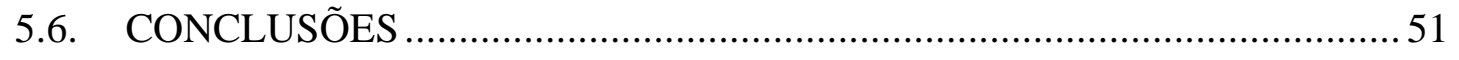

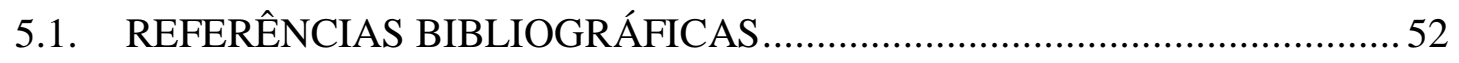

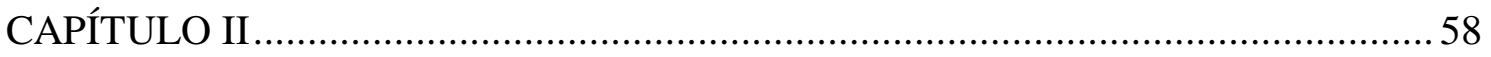

6. O USO DO GESSO AUMENTA O ESTOQUE DE CARBONO DO SOLO CULTIVADO COM CANA-DE-AÇÚCAR NO CERRADO ...................................59

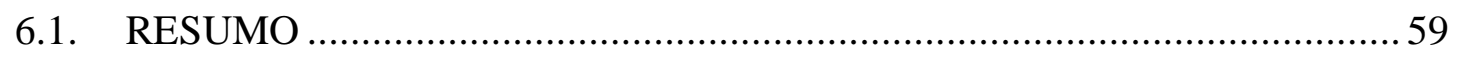

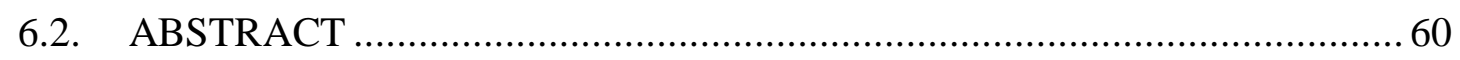

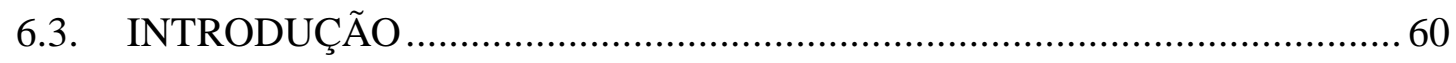

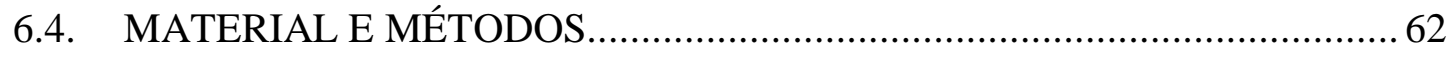

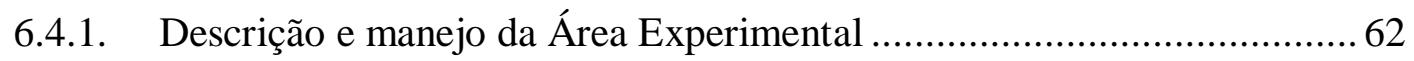

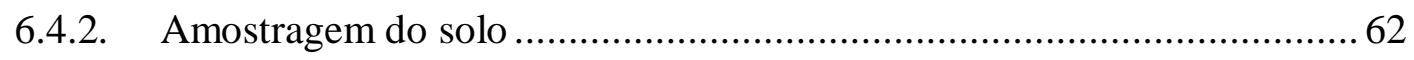

6.4.3. Determinação da biomassa de colmos e palha ..................................... 63

6.4.4. Determinação do teor e do estoque de carbono total .............................. 64

6.4.5. Determinação de carbono orgânico .................................................... 65

6.4.6. Determinação do teor e do estoque de carbono particulado ....................6 65 
6.4.7. Determinação do estoque de carbono associado aos minerais ................. 65

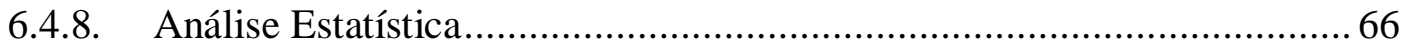

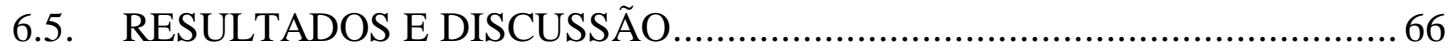

6.5.1. Biomassa de colmos, produção total de palha da cana-de-açúcar e carbono

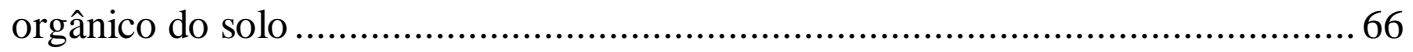

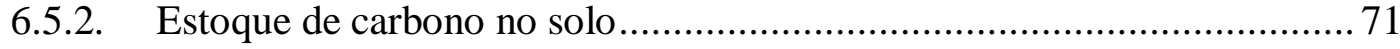

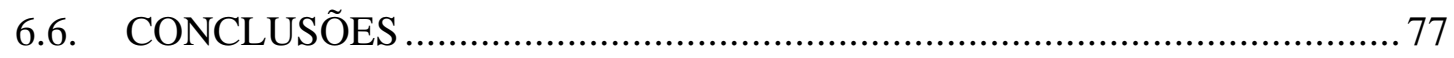

6.7. REFERÊNCIAS BIBLIOGRÁFICAS .................................................... 78

ANEXOS 


\section{LISTA DE FIGURAS}

Figura 5.1: Incorporação do calcário com grade aradora na camada de $0-20 \mathrm{~cm}$ do solo (a) e aração com arado aivecas na camada de 0-40 cm (b).

Figura 5.2: Precipitação pluviométrica durante o ciclo de cana planta. As setas indicam as quatro irrigações para proporcionar brotação dos rebolos, nos dias 4/08/2009, 14/08/2009, 17/08/2009 e 17/09/2009 compostas de $25 \mathrm{~mm}$ para cada dia. .36

Figura 5.3: Precipitações pluviométricas durante o ciclo das três canas socas e irrigações suplementares. $\mathrm{Na} 1^{\mathrm{o}}$ soca as irrigações foram compostas de duas aplicações de $57,4 \mathrm{~mm}(31 / 08$ e $14 / 09 / 2010)$, totalizando $114,8 \mathrm{~mm}$. Na $2^{\circ}$ soca nos dias 01/09 e 15/09 e 29/09/2011 e na $3^{\circ}$ soca nos dias 27/08, 10/09 e 24/09/2012, aplicou-se para cada ciclo $150 \mathrm{~mm}$, divididos em três irrigações de $50 \mathrm{~mm}$.

Figura 5.4: Ilustração de coleta das sub-amostras na parcela experimental. Imagem dos seis pontos de coleta das sub-amostras para a composição de uma amostra composta deformada (a) e representação esquemática dos seis pontos de coleta das amostras deformadas (b).

Figura 5.5: Produtividade de colmos por hectare (TCH) (a) e de açúcares redutores totais (ART) (b) de cana-de-açúcar nos ciclos de cana planta (2009-10), primeira soca (2010-11), segunda soca (2011-12) e terceira soca (2012-13) em resposta a doses de gesso aplicado no plantio da cana, em Latossolo muito argiloso. *Significativo pelo teste $t(\mathrm{p}<0,05)$.......

Figura 5.6: $\mathrm{pH}$ em $\mathrm{H}_{2} \mathrm{O}(\mathrm{a}), \mathrm{pH}$ em $\mathrm{CaCl}_{2}$ (b), teor de alumínio trocável ( $\mathrm{Al}^{3+}$ ) (c) e saturação de alumínio (m\%) (d), em cinco profundidades(0-20; 20-40; 40-60; 60-80 e 80-100 cm) de um Latossolo Vermelho, após cultivo de cana-de-açúcar terceira soca em resposta a doses de gesso aplicado no plantio da cana (50 meses após aplicação). *Significativo pelo teste $t(\mathrm{p}<0,05)$.

Figura 5.7: Cálcio trocável $\left(\mathrm{Ca}^{2+}\right)(\mathrm{a})$, magnésio trocável $\left(\mathrm{Mg}^{2+}\right)(\mathrm{b})$, potássio trocável $\left(\mathrm{K}^{+}\right)(\mathrm{c})$ e teor de sulfato $\left({\mathrm{S}-\mathrm{SO}_{4}}^{2-}\right)(\mathrm{d})$, em cinco profundidades $(0-20 ; 20-40 ; 40-60 ; 60$ 80 e 80-100 cm) de um Latossolo Vermelho, após a terceira soca em resposta a doses de gesso aplicado no plantio da cana (50 meses após aplicação). ${ }^{*}$ Significativo pelo teste $t$ $(\mathrm{p}<0,05)$.

Figura 5.8: Saturação de cálcio na CTC efetiva (a) e saturação de bases na CTC efetiva (b), em cinco profundidades $(0-20 ; 20-40 ; 40-60 ; 60-80$ e 80-100 cm) de um Latossolo 
Vermelho, após terceira soca em resposta a doses de gesso aplicado no plantio da cana (50 meses após aplicação). *Significativo pelo teste $t(\mathrm{p}<0,05)$. 48

Figura 5.9: Capacidade de troca catiônica à pH 7 (CTC pH 7) (a) e matéria orgânica facilmente oxidável do solo (MO) (b), em cinco profundidades $(0-20 ; 20-40 ; 40-60 ; 60$ 80 e 80-100 cm) de um Latossolo Vermelho, após cultivo de cana-de-açúcar terceira soca em resposta a doses de gesso aplicado no plantio da cana (50 meses após aplicação). * Significativo pelo teste $t(\mathrm{p}<0,05)$. .50

Figura 5.10: Relação entre os teores de matéria orgânica facilmente oxidável (MO) e a CTC ( $\mathrm{pH}$ 7), de um Latossolo Vermelho na camada 0-100 cm, obtidos após a colheita da terceira soca de cana-de-açúcar com e sem a aplicação de gesso (50 meses após aplicação).

Figura 6.1: Ilustração de coleta das sub-amostras na parcela experimental. Imagem dos seis pontos de coleta das sub-amostras para a composição de uma amostra composta deformada (a) e representação esquemática dos pontos de coleta das amostras deformadas, seis pontos e das amostras indeformadas, três pontos (b).

Figura 6.2: Biomassa de colmos $\left(\mathrm{Mg} \mathrm{ha}^{-1}\right)$ (a) e de palha produzida (b) em quatro cortes de cana-de-açúcar (cana planta e três socas) em resposta a doses de gesso aplicado no plantio, em Latossolo muito argiloso. *Significativo pelo teste $t(p<0,05) .67$ Figura 6.3: Teor de carbono orgânico (CO) nas camadas de 0-20, 20-40 e 40-60 cm antes do início do experimento (controle) e em resposta a doses de gesso aplicado no plantio de cana-de-açúcar nas camadas de 0-20, 20-40, 40-60, 60-80 e 80-100 cm após quatro cortes (50 meses após aplicação). * Significativo pelo teste t para os tratamentos 0 e $5 \mathrm{Mg} \mathrm{ha}^{-1}(\mathrm{p}<0,05)$.

Figura 6.4: Relação entre os teores de carbono total (CT) e carbono orgânico (CO) de amostras de solo na camada de 0-100 cm. Dados obtidos após a terceira soca de canade-açúcar com e sem aplicação de gesso. 71

Figura 6.5: Estoque de carbono total (CT) nas profundidades de 0-20 e 20-40cm (a) e 40-60, 60-80 e 80-100cm (b) após quatro cortes de cana-de-açúcar (cana planta e três socas) em resposta a doses de gesso aplicado no plantio. Tratamentos seguidos pela mesma letra maiúscula e profundidades pela mesma letra minúscula não diferem estatisticamente pelo teste $\mathrm{t}(\mathrm{p}<0,05)$.

Figura 6.6: Estoque de carbono particulado (CP) nas camadas de 0-20 e 20-40 cm (a) e 40-60, 60-80 e 80-100 cm (b) e estoque de carbono associado aos minerais (CM) nas camadas de 0-20 e 20-40 cm (c) e 40-60, 60-80 e 80-100 cm (d), após quatro cortes de 
cana-de-açúcar, cana planta e três socas, em resposta a doses de gesso aplicado no plantio. Tratamentos seguidos pela mesma letra maiúscula e profundidades pela mesma

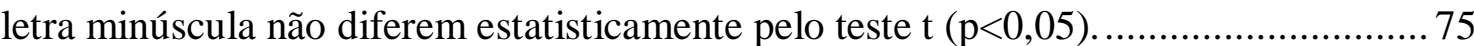




\section{LISTA DE TABELAS}

Tabela 5.1: Características químicas do solo da área experimental antes da correção e

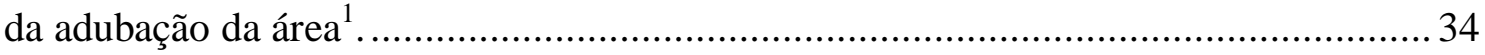

Tabela 6.1: Densidade do solo após o cultivo por quatro anos com cana-de-açúcar, sem e com aplicação de gesso.

Tabela 6.2: Carbono armazenado pelo palhiço de cana-de-açúcar e no solo, sem e com aplicação de gesso, após 4 cortes. .76 


\section{RESUMO GERAL}

O uso do gesso é uma tecnologia eficiente em promover maior crescimento e distribuição do sistema radicular das plantas na subsuperfície dos solos do Cerrado, devido à correção dos baixos teores de bases trocáveis e elevada saturação por alumínio. Com isso, tem-se obtido ganhos no rendimento das culturas, em especial quando ocorrem veranicos. Além de maior produtividade das culturas, há também a possibilidade de aumentar o teor de matéria orgânica do solo, principalmente em culturas que aportam grandes quantidades de biomassa radicular nas camadas mais profundas. Assim a cana-de-açúcar, com alta demanda hídrica e produção de biomassa, reúne condições de responder, de forma positiva, em produtividade e teor de matéria orgânica do solo, ao uso do gesso. No entanto, ainda são poucos os estudos que avaliam os efeitos do gesso na produção de cana-de-açúcar em solos do Cerrado. Portanto, o objetivo desse trabalho foi avaliar a produtividade de cana-de-açúcar, atributos químicos e o estoque de carbono no solo de Cerrado sob uso de gesso. O experimento foi conduzido na área experimental localizada na Embrapa Cerrados, em Planaltina DF. O delineamento do experimento constituiu-se de blocos casualizados, com 4 repetições e 2 tratamentos: testemunha $\left(0 \mathrm{Mg} \mathrm{ha}^{-1}\right)$ e dose recomendada $\left(5 \mathrm{Mg} \mathrm{ha}^{-1}\right)$. Aplicou-se o gesso a lanço na superfície do solo após o plantio da cana-de-açúcar com irrigação para o estabelecimento da cultura na estação seca. O rendimento de colmos, a qualidade tecnológica, biomassa de colmos e a produção de palha foram avaliados na cana planta e em três socas. Efetuou-se a coleta de solo após avaliação da terceira soca em sete camadas $(0-5 ; 5-10 ; 10-20 ; 20-40 ; 40-60 ; 60-80$ e $80-100 \mathrm{~cm})$, para a determinação dos atributos químicos, carbono orgânico, carbono total, carbono particulado e densidade do solo. $\mathrm{O}$ uso do gesso proporcionou aumento na produtividade de colmos, de açúcares redutores totais, biomassa de colmos e palha da cana planta e nas três socas. Elevou os teores de $\mathrm{Ca}^{2+}, \mathrm{Mg}^{2+} \mathrm{e} \mathrm{SO}_{4}{ }^{2-}$ e reduziu a saturação por alumínio nas camadas de 20-100 cm, 40-100 cm, 0-100 cm e 40-100 cm, respectivamente. Além disso, o gesso também propiciou maior acúmulo de matéria orgânica e maiores valores da capacidade de troca catiônica na camada de 40-100 cm. O gesso ainda aumentou em $5,4 \mathrm{Mg} \mathrm{ha}^{-1}$ o estoque de carbono total (CT) no solo na camada de 0-100 cm, sendo 4,4 $\mathrm{Mg} \mathrm{ha}^{-1}$ na camada de 40-100 cm. O estoque de carbono particulado (CP) na camada de 40-100 cm aumentou em 18,4\% devido ao uso do gesso e representou $15,9 \%$ do incremento observado do estoque de CT, enquanto que o estoque de carbono associado aos minerais (CM) aumentou 6,8\% com aplicação de gesso, representando $84,1 \%$ do acréscimo no estoque de CT. Do incremento total obtido nos estoques de C devido ao uso do gesso, $80 \%$ ocorreram na camada de $40-100 \mathrm{~cm}$.

Palavras-chave: matéria orgânica do solo, carbono particulado, veranicos, sequestro de carbono 


\begin{abstract}
Gypsum is an efficient technology to promote higher growth and distribution of root system of plants in subsurface layers of the Cerrado soils, due to the correction of low levels of exchangeable calcium and high aluminum saturation. Consequently, higher yields have been obtained, particularly under dry spell conditions. Thus, in addition to higher crop yields, there is also the possibility of increasing organic matter content in the soil, especially in crops that allocate large amounts of root biomass in the deeper layers. Sugarcane is a high biomass production and water demanding crop and the use of gypsum could increase yield soil and organic matter content. However, there are few studies assessing the effects of gypsum over sugarcane production in Cerrado soils. This study aimed to evaluate sugarcane yield, chemical soil properties and carbon stock in a Cerrado soil under the of use gypsum. The experiment was carried out at Embrapa Cerrados, in Planaltina - DF and was established in a randomized block design with four replicates and two treatments: control $\left(0 \mathrm{Mg} \mathrm{ha}^{-1}\right)$ and recommended dose $\left(5 \mathrm{Mg} \mathrm{ha}^{-1}\right)$. Gypsum was applied broadcast on the soil surface after planting of sugarcane in the winter, with irrigation for crop establishment. The yield of stalk, technological quality, stalk biomass and straw production were evaluated in plant crop and three ratoon crops. Soil samples were taken after harvest of the third ratoon crop in seven layers (0-5; 5-10; $10-20 ; 20-40 ; 40-60 ; 60-80$ and $80-100 \mathrm{~cm}$ ) in order to determine soil chemical properties, organic carbon, total carbon, particulate organic carbon and bulk density. The use of gypsum increased sugarcane, total reducing sugars, stalk biomass and straw yields of plant crop and the three ratoon crops. Also, increased the $\mathrm{Ca}^{2+}, \mathrm{Mg}^{2+}$ and $\mathrm{SO}_{4}{ }^{2-}$ levels and decreased the saturation of aluminum in layers of $20-100 \mathrm{~cm}, 40-100 \mathrm{~cm}, 0$ $100 \mathrm{~cm}$ and 40-100 $\mathrm{cm}$, respectively. In addition, gypsum also provided greater accumulation of soil organic matter and higher values of cation exchange capacity in the layer of 40-100 cm. Gypsum also increased in 5.4 $\mathrm{Mg} \mathrm{ha}^{-1}$ the total carbon stock (CT) in the $0-100 \mathrm{~cm}$ soil layer, with $4.4 \mathrm{Mg} \mathrm{ha}^{-1}$ in the layer of $40-100 \mathrm{~cm}$. Particulate carbon stock $(\mathrm{CP})$ at $40-100 \mathrm{~cm}$ layer was increased by $18.4 \%$ due to use of gypsum and represented $15.9 \%$ of the increase observed in the CT stock, while the carbon stock associated to minerals (CM) increased $6.8 \%$ with gypsum applications, representing $84.1 \%$ of the increase in CT stock. From the total increase obtained in C stocks due to the use of gypsum, $80 \%$ occurred at a depth of $40-100 \mathrm{~cm}$.
\end{abstract}

Keywords: soil organic matter, particulate carbon, dry spells, carbon sequestration 


\section{INTRODUÇÃO GERAL}

Um dos maiores desafios da agricultura brasileira é produzir de forma sustentável, garantindo o suprimento de alimentos e energia e preservando os recursos naturais disponíveis. No entanto, as mudanças climáticas resultantes do aquecimento global são reflexo em grande parte do desmatamento, mudanças do uso do solo e agropecuária, responsáveis por $62 \%$ das emissões de gases de efeito estufa no Brasil (MCTI, 2013).

Esse cenário evidencia a necessidade de se desenvolver uma agricultura de baixa emissão de carbono (C) utilizando o solo como dreno desse elemento e aumentando os teores e a qualidade da matéria orgânica do solo (Lal, 2004; Lal, 2005). Dessa maneira, no contexto agrícola é possível produzir alimentos de forma sustentável com a incorporação das tecnologias existentes e também as que estão em desenvolvimento, contribuindo de forma efetiva na mitigação do aumento de $\mathrm{CO}_{2}$ atmosférico (Vezzani \& Mielniczuk, 2011; Signor et al., 2014).

A agropecuária brasileira tem atendido a demanda interna e de outros países em alimentos e energia, com destaque para a produção de carnes, grãos, açúcar e álcool (FAOESTAT, 2012). Tal produção tem sido proporcionada pela incorporação do bioma Cerrado à agricultura, onde as tecnologias geradas nas últimas quatro décadas propiciaram a incorporação 79,1 milhões de hectares na agropecuária brasileira (Sano et al., 2008). Nesse sentido, destacam-se a melhoria da fertilidade do solo através da correção da acidez e adequação nutricional para diferentes sistemas de produção.

A correção da acidez superficial e em profundidade nos solos do Cerrado, através da utilização de calcário e gesso (Sousa \& Lobato 2004; Sousa et al., 2004), foi determinante para o desenvolvimento agrícola nesse bioma. Associado a isso, a estacionalidade climática e interrupções pluviométricas durante a estação chuvosa (veranicos) (Cochrane \& Azevedo, 1988; Lopes et al., 2012) tornam a tecnologia de uso do gesso ainda mais importante.

O gesso tem sido utilizado em soja, milho, pastagens e também em culturas perenes, como a cana-de-açúcar, resultando em aumentos de produtividade devido ao uso mais eficiente de água e de nutrientes do solo (Sousa \& Rein, 2009; Demattê et al., 2011; Rampim et al., 2013). A maior estabilidade de produção condicionada por essa tecnologia contribui para a expansão da área cultivada no Cerrado. 
A cana-de-açúcar foi uma das culturas de maior expansão no Brasil na última década, com acréscimo de 54,2\% em área, enquanto que a expansão de área para produção de grãos foi de $20 \%$ (CONAB, 2015). A maior parte dessa expansão, em termos relativos, ocorreu no Cerrado, onde o crescimento na região Centro-Oeste para a cana-de-açúcar alcançou 220\%, enquanto que para grãos foi de 52\% (CONAB, 2015). Esse desenvolvimento da agricultura brasileira no Cerrado só foi possível graças aos trabalhos de adequação na fertilidade dos solos e melhoramento vegetal.

O crescimento do cultivo da cana-de-açúcar está associado principalmente à sua importância para a matriz energética brasileira, com a produção de etanol e mais recentemente a geração de energia elétrica a partir da palha e bagaço, além da produção de açúcar (Macedo et al., 2008; Santos et al., 2012). Adicionalmente, a substituição dos combustíveis fósseis pelo etanol tem reduzido a emissão de gases do efeito estufa (Goldemberg, 2009).

A alta produção de biomassa da cana-de-açúcar requer alta demanda hídrica (Hernandes et al., 2014) e seu cultivo de forma eficiente no Cerrado só é possível utilizando tecnologias que permitam desenvolvimento adequado do sistema radicular no perfil do solo. Para isso, utiliza-se calcário na camada superficial $(0-40 \mathrm{~cm})$, que além de corrigir a acidez fornece nutrientes para essa cultura (cálcio e magnésio). Já para o desenvolvimento de raízes em profundidade $(40-100 \mathrm{~cm})$ utiliza-se o gesso, que é ainda fonte dos nutrientes cálcio e enxofre (Caires et al., 2001; Caires et al., 2006; Sousa et al., 2004).

Como a cana-de-açúcar produz grande quantidade de biomassa de parte aérea e raízes, há possibilidade de contribuir de forma relevante com incremento de $\mathrm{C}$ no solo (Molina et al., 2001). A maior contribuição das raízes no incremento de $\mathrm{C}$ ao solo em relação à biomassa aérea está relacionada à recalcitrância dos compostos que predominam nos tecidos radiculares e a proteção física proporcionada pelos agregados do solo, que minimizam a mineralização do $\mathrm{C}$ desses compostos pela microbiota do solo (Rasse et al., 2005).

Considerando o potencial das raízes de cana-de-açúcar em incorporar $\mathrm{C}$ ao solo e a necessidade de se obter maiores produtividades, torna-se necessário melhor compreensão acerca do efeito do gesso sobre esses parâmetros. 


\section{OBJETIVOS}

\subsection{Objetivo geral}

Avaliar a produtividade de cana-de-açúcar, atributos químicos e o estoque de carbono no solo de Cerrado sob uso de gesso.

\subsection{Objetivos específicos}

1. Determinar a produtividade de colmos, qualidade tecnológica e palha de cana planta e três socas com aplicação de gesso.

2. Quantificar os atributos químicos do solo após 50 meses da aplicação de gesso.

3. Avaliar carbono total e suas frações particulada e associada aos minerais no solo após quatro cortes de cana-de-açúcar com aplicação de gesso.

\subsection{Hipóteses}

A aplicação de gesso em solo do Cerrado cultivado com cana-de-açúcar aumenta a eficiência de uso dos nutrientes e o estoque de carbono. 


\section{REVISÃO DE LITERATURA}

\subsection{Agricultura no Cerrado e ocorrência de veranicos}

A agricultura no Cerrado antecedente à década de 1970 era realizada em pequena escala em áreas com solos de maior fertilidade natural, principalmente, para subsistência e com uso de pecuária extensiva. Tais condições estavam relacionadas às limitações climáticas e principalmente aos baixos teores de nutrientes apresentados pelos Latossolos, classe de solo predominante e que ocupa $46 \%$ da área no Cerrado (Macedo, 1996; Calaça \& Dias, 2010; Castro et al., 2011).

O limitado desenvolvimento das culturas no Cerrado associava-se a reduzida fertilidade natural e a elevada acidez dos solos, tanto em superfície (0 a $20 \mathrm{~cm})$ como em subsuperfície (camada abaixo de $20 \mathrm{~cm}$ ) (Ritchey et al., 1982). Isso tornava a agricultura inviável ou de alto risco, na ausência de técnicas que favorecessem a correção das propriedades químicas dos solos (Sousa \& Lobato, 2003; Sousa \& Rein, 2011).

A partir de políticas públicas voltadas para o desenvolvimento da região central do país, concomitantemente ao avanço de pesquisas com enfoque no lançamento de variedades adaptadas a esse domínio morfoclimático (Spehar, 1994) e as tecnologias de utilização de fertilizantes e corretivos aos solos, tornou-se possível a obtenção de elevadas produtividades para o Cerrado (Sousa \& Lobato, 2004; Spehar \& Trecenti, 2011).

Atualmente o Cerrado representa a fronteira de expansão do agronegócio brasileiro, consolidado para a região Centro-Oeste e expandindo para as regiões Norte e Nordeste, por intermédio principalmente de tecnologias voltadas para a adequação da fertilidade dos solos e características climáticas apresentadas em cada região (Damico \& Nassar, 2007; Miranda, 2012; Silva et al., 2013). Exemplificando a importante contribuição do Cerrado para agricultura do país e baseando-se em dados da Região Centro-Oeste, na última década a expansão do cultivo de soja e milho foi de 7,6 milhões de hectares, o que representou incremento de $57,7 \%$. Nesse mesmo período, para a cana-de-açúcar a expansão foi de 1,2 milhões de hectares, correspondendo a $220 \%$ de aumento (CONAB, 2015).

Ainda assim, muitos fatores têm limitado a elevação da produtividade das culturas no Cerrado, como a acentuada deficiência de cálcio $\left(<0,4 \mathrm{cmol}_{\mathrm{c}} / \mathrm{dm}^{3}\right)$ no perfil 
dos solos, atingindo $86 \%$ da área agricultável e elevados valores de saturação por alumínio (> 10\%), que predomina em 70\% dos solos do Cerrado (Sousa et al., 2004). Além disso, existe alta probabilidade de ocorrência de interrupções pluviométricas durante a estação chuvosa, os "veranicos", cuja ocorrência e duração são variáveis e atinge praticamente toda a área do Cerrado (Cochrane, 1988; Assad et al., 1993; Lopes et. al., 2012).

O impacto ocasionado na produtividade e na qualidade das culturas pelos veranicos no Cerrado é ainda maior, considerando que sua ocorrência geralmente coincide com o período de floração, maturação e enchimento de grãos, estádios das culturas que requerem elevada disponibilidade hídrica (Franchini et al., 2009, Menezes et al., 2010; Cruz et al., 2010). Os veranicos podem ter seu efeito negativo intensificado para as culturas quando relacionados com solos que apresentam capacidade reduzida de armazenar água, principalmente solos de textura arenosa (Thomas et al., 2000).

A deficiência de nutrientes e a presença de elevada saturação por alumínio limitam o desenvolvimento e o crescimento uniforme do sistema radicular das culturas tanto na superfície como em profundidade. Em contrapartida, a calagem apresenta-se como prática agrícola bem difundida e já estabelecida para a correção de tal deficiência no Cerrado, propiciando crescimento do sistema radicular na camada onde é incorporado (Rheinheimer et al., 2000; Amaral \& Anghinoni, 2001; Caires et al., 2004).

Assim, práticas agrícolas que possibilitem a correção dos teores dos nutrientes em profundidade, favorecendo o crescimento do sistema radicular e, consequentemente, reduzindo o efeito dos veranicos, vem sendo estudadas e utilizadas para o Cerrado, como o uso do gesso agrícola.

\subsection{Uso do gesso no Cerrado: produção e reações no solo}

No que tange ao período de 1974 a 1984 foram produzidos pela indústria brasileira de fertilizantes fosfatados aproximadamente 15,6 milhões de toneladas de gesso agrícola. Por se tratar de um subproduto e não possuir adequada finalidade, o gesso permanecia estocado em depósitos, acumulando o equivalente a 377 milhões de dólares sob a forma de enxofre (Rocha, 1985). A partir desse período, iniciaram-se pesquisas voltadas para a utilização do gesso na agricultura, principalmente para o Cerrado e com diversos objetivos, como no fornecimento de nutrientes e condicionador do ambiente radicular, corrigindo a acidez subsuperficial do solo suprimindo algumas 
das limitações apresentadas por esta região à exploração agrícola em crescente expansão.

O gesso ou sulfato de cálcio $\left(\mathrm{CaSO}_{4} \cdot 2 \mathrm{H}_{2} \mathrm{O}\right)$ é um sal neutro que pode ser obtido em jazidas de gipsita, presentes no Brasil nos estados de Pernambuco e Maranhão (Oliveira et al., 2012). Pode ainda ser obtido como um subproduto da indústria do ácido fosfórico, para produção de fertilizantes fosfatados, como em Catalão-GO, Cubatão-SP e Uberaba-MG (Embrapa, 2014).

No processo de produção de fertilizantes fosfatados, a reação da rocha fosfática (apatita) com ácido sulfúrico e água gera como produto o ácido fosfórico e como subprodutos o gesso e pequenas quantidades de ácido fluorídrico, resultando na formação de 5,5 toneladas de gesso a partir da produção de 1 tonelada de ácido fosfórico (Malavolta, 1992). Assim, o gesso contém em sua formulação cerca de 19\% de cálcio e $15 \%$ de enxofre na forma de sulfato de cálcio (Sousa \& Lobato, 2004).

As alterações provocadas em profundidade no solo com a aplicação do gesso são possíveis em decorrência da maior solubilidade e reações do sulfato de cálcio no solo quando comparada ao calcário (Ernani et al., 2001; Caíres et al., 2006). No entanto, tais alterações ocorrem apenas posteriormente à correção da acidez superficial do solo, através da calagem.

Para a recomendação da gessagem no Cerrado, deve-se efetuar amostragem das camadas subsuperficiais do solo de 20 a $40 \mathrm{~cm}$ e de 40 a $60 \mathrm{~cm}$ para culturas anuais e até 60 a $80 \mathrm{~cm}$ para culturas perenes. Se tais camadas apresentarem teores de cálcio inferiores a $0,5 \mathrm{cmol}_{\mathrm{c}} \mathrm{dm}^{-3}$ e saturação por alumínio maior que $20 \%$, há grande probabilidade de resposta ao gesso (Sousa \& Lobato, 2004). A quantidade de gesso a ser aplicada relaciona-se diretamente ao teor de argila presente no solo, este associado ao poder tampão de sulfato na solução do solo (Sousa et al., 1992).

Desse modo, após a dissolução do gesso, o sulfato $\left(\mathrm{SO}_{4}{ }^{-2}\right)$ acompanhado por cátions movimenta-se para as camadas inferiores no solo, possibilitando o fornecimento de nutrientes como o cálcio, magnésio e potássio em profundidade. Além disso, o maior teor de cálcio dissociado do sulfato promove o deslocamento do alumínio do complexo de troca $\left(\mathrm{Al}^{+3}\right)$ para a solução, formando o par iônico $\mathrm{AlSO}_{4}{ }^{+}$não tóxico às culturas (Ritchey et al., 1980; Sousa et al., 1992; Ernani et al., 2001; Zambrosi et al., 2007; Serafim et al., 2012; Rampim et al., 2013).

O gesso também promove efeitos benéficos nas propriedades físicas do solo, podendo aumentar a infiltração e a capacidade de retenção de água. Isso ocorre como 
resultado da elevação da floculação da argila, possibilitando maior estabilidade para os agregados, redução da densidade e a prevenção do encrostamento superficial (Borges et al., 1997; Favaretto et al., 2006; Rosa Junior et al., 2007).

Em decorrência dos efeitos benéficos do gesso sobre as propriedades químicas e físicas dos solos, sua utilização favorece o melhor aproveitamento da água disponível no solo pelas culturas, devido ao aumento do volume de solo explorado pelas raízes, reduzindo os efeitos negativos ocasionados por veranicos (Sobral et al., 2009).

O fornecimento de nutrientes em profundidade e a correção da toxidez de alumínio são responsáveis por melhorar o ambiente radicular no perfil do solo. Tais características tornam o gesso um condicionador de crescimento radicular em profundidade, principalmente para os solos do Cerrado, com alta concentração das raízes em superfície quando só se utiliza o calcário, tornando as culturas altamente susceptíveis aos efeitos de veranicos. Dessa forma, o gesso vem sendo amplamente utilizado com o objetivo de reduzir as perdas de produtividade nessa Região, favorecendo o crescimento das raízes na subsuperfície e proporcionando melhor aproveitamento da água no perfil do solo (Sousa et al., 2004; Soratto \& Crusciol, 2008; Ramos et al., 2013).

\subsection{Utilização do gesso na agricultura do Cerrado}

\subsubsection{Culturas anuais e perenes}

A adoção da gessagem para a agricultura no Cerrado tem evoluído a partir da última década, principalmente para aquelas culturas de elevada importância econômica para o agronegócio brasileiro. No período de 1999 a 2012 o uso do gesso para a cultura de soja cresceu em 6,46 vezes, passando de 76 mil para 491 mil toneladas. Na cultura do milho a utilização cresceu 3,83 vezes no período de 1999 a 2007 (Embrapa, 2013).

$\mathrm{O}$ incremento em produtividade a partir da aplicação do gesso vem sendo observado na maioria das culturas anuais, com destaque para milho, soja, algodão e trigo. Em algodão e soja, observou-se incremento de $44,4 \%$ e $21,2 \%$, respectivamente,

em resposta a aplicação de $3 \mathrm{Mg} \mathrm{ha}^{-1}$ de gesso (Sousa et al., 2008). No trigo verificou-se incremento linear para a produtividade em função das doses de gesso (Rampim et al., 2013).

Os efeitos positivos alcançados pelas culturas em consequência da melhor distribuição do sistema radicular no perfil do solo resultam dos maiores teores 
disponíveis de cálcio e da correção da toxidez de alumínio, obtidos a partir da técnica de gessagem (Caires et al., 2001; Caires et al., 2006; Saldanha et al., 2007).

Tais efeitos são intensificados quando consideradas as características químicas apresentadas pelos solos do Cerrado, que normalmente apresentam baixa fertilidade natural e elevada saturação por alumínio (Castro et al., 2011; Carducci et al., 2012). Essas limitações podem ocasionar a concentração de $90 \%$ do sistema radicular da cultura do milho na camada de 0-30 cm do solo sem a aplicação do gesso, ocorrendo distribuição do sistema radicular até os $75 \mathrm{~cm}$, após a aplicação desse produto (Sousa et al., 2004).

$\mathrm{O}$ crescimento adequado do sistema radicular das culturas favorece o melhor aproveitamento de água disponível no solo e melhora a eficiência na absorção de nutrientes, seja para aqueles de alta ou baixa mobilidade no solo, como o nitrogênio e o fósforo. Consequentemente, obtêm-se maiores teores foliares de nutrientes após a aplicação do gesso para diversas culturas (Caires et al., 2002; Soratto \& Crusciol, 2007; Sousa et al., 2008; Sorato et al., 2010).

O aumento da produtividade também pode ser alcançado para culturas perenes como o café, em consequência do cálcio fornecido pela aplicação do gesso e por se tratar do terceiro nutriente mais exigido e exportado pelo cafeeiro (Guimarães, 1992; Silva et al., 2004; Raij, 2008). A relação custo-benefício da utilização do gesso é muito alta para essa cultura; ficando em torno de $\mathrm{R} \$ 25,00$ de ganho em cada real investido (Embrapa, 2013).

Para gramíneas e leguminosas forrageiras têm sido alcançados maiores rendimentos de matéria seca e absorção de nutrientes, aumentando o valor nutritivo das mesmas (Mesquita et al., 2002; Custódio et al., 2006; Oliveira et al., 2009; Guelfi et al., 2013). Para a leucena, uma leguminosa forrageira, o rendimento de matéria seca aumentou em 55\%, já para Brachiaria decumbens e Brachiaria brizantha, gramíneas forrageiras, ocorreu aumento de $260 \%$ e 50\%, respectivamente, após aplicação do gesso (Sousa et al., 2001).

\subsubsection{Cana-de-açúcar}

A expansão da área cultivada com cana-de-açúcar na última década no Brasil foi de 3,16 milhões de hectares, acumulando crescimento de 54\% (CONAB, 2015). Tal evolução é reflexo da expansão dessa cultura para o Cerrado na Região Centro-Oeste, 
onde os estados do Mato Grosso e Goiás obtiveram os maiores incrementos relativos em área com cana-de-açúcar de 380\% e 331\%, respectivamente (CONAB, 2015).

A produtividade média prevista para a safra 2014/15 na região Centro-Oeste para a cana-de-açúcar é de 73,7 $\mathrm{Mg} \mathrm{ha}^{-1}$ (CONAB, 2015), no entanto, pesquisas demonstram que o potencial produtivo dessa cultura pode atingir valores superiores à $200 \mathrm{Mg} \mathrm{ha}^{-1}$ (Waclawovsky et al., 2010). Vários fatores atuam de forma conjunta para a definição da produtividade, dentre os quais a disponibilidade hídrica e o manejo do solo certamente estão entre os mais importantes em cana-de-açúcar.

A aplicação de gesso em cana-de-açúcar tem mostrado efeitos positivos em decorrência do fornecimento de cálcio e enxofre e ao efeito condicionador de subsuperfície. Após aplicação de $4 \mathrm{Mg} \mathrm{ha}^{-1}$ de gesso, observou-se incremento da produtividade de colmos em torno de $15 \%$, além de permitir maior longevidade da soqueira (Lorenzetti et al., 1992). A redistribuição de nutrientes em profundidade e a consequente maior exploração do solo pelo sistema radicular permitem ganhos em produtividade de colmos de até $12 \mathrm{Mg} \mathrm{ha}^{-1}$ (Demattê et al., 2011).

O favorável desenvolvimento radicular com o uso de gesso permite às plantas de cana-de-açúcar maior exploração do ambiente e, consequentemente, melhor uso da água e nutrientes. Rocha et al. (2008) verificaram que $80 \%$ do sistema radicular foi distribuído na camada de 40-80 cm com a aplicação de 4,62 $\mathrm{Mg} \mathrm{ha}^{-1}$ de gesso, enquanto que na ausência de gesso apenas 30\% do sistema radicular atingiu esta profundidade. Vitti et al. (1992) também encontraram melhor distribuição do sistema radicular de cana-de-açúcar após aplicação de gesso.

Além de possibilitar maior produtividade das culturas com o melhor desenvolvimento do sistema radicular no perfil do solo, a utilização o gesso pode ser interessante do ponto de vista da sustentabilidade da agricultura, através da maior incorporação de matéria orgânica no perfil e consequentemente elevação do estoque de carbono (Silva et al., 2013).

\subsection{Matéria orgânica do solo na perspectiva da agricultura de baixa emissão de carbono}

\subsubsection{Importância da matéria orgânica do solo}

Inúmeras são as conceituações para matéria orgânica do solo (MO), no entanto, a de maior abrangência foi definida por Campbell (1978), caracterizando a MO como 
uma mistura de resíduos de plantas e de animais em vários estágios de decomposição, de substâncias sintetizadas microbiológica e quimicamente a partir do decaimento de produtos e de corpos de microrganismos vivos e mortos e de pequenos animais, e suas sobras em decomposição. Aproximadamente $58 \%$ da MO é constituída por carbono (Stevenson \& Cole, 1999).

Apesar de a MO representar apenas de 1,5 a 4,5\% do volume do solo em Latossolos do Cerrado, sua importância para a manutenção da produtividade dos sistemas agrícolas é incontestável. Além disso, é considerada indicadora da qualidade do solo, devido a sua alta sensibilidade às alterações provocadas pelo manejo dos sistemas agrícolas (Conceição et al., 2005, Papa et al., 2011; Chaves et al., 2012). Dessa forma, a MO influencia os atributos físicos, químicos e biológicos do solo.

Nos solos do Cerrado a MO é responsável por 75 a $85 \%$ da capacidade de troca de cátions, devido à ionização dos grupos carboxílicos e fenólicos (Lopes, 1977; Ciotta et al., 2003; Vendrame et al., 2010). A MO exerce também influência direta na agregação do solo, a partir da interação entre as partículas orgânicas do solo e minerais, possibilitando a formação de agregados com elevada estabilidade, seguindo uma ordem hierárquica de agregação (Tisdall \& Oades, 1982), protegendo a MO da rápida oxidação e contribuindo para o aumento do estoque de carbono no solo (Mikha \& Rice, 2004).

Maiores teores de MO também refletem em benefícios para os atributos físicos do solo, como redução da densidade, proporcionando maior resistência do solo a compactação (Braida et al., 2006; Braida et al., 2010), aumento da capacidade do solo em reter água (Tormena et al., 2004; Sá et al., 2010) e redução das temperaturas médias do solo (Costa et al., 2003). Esses benefícios influenciam diretamente a microbiota do solo, favorecendo a ciclagem e a disponibilidade de nutrientes para as plantas (Carneiro et al., 2009; Costa et al., 2013).

Dessa forma, a importância do manejo da MO para manutenção dos sistemas agrícolas é amplamente conhecida. Atualmente, inúmeros estudos vêm sendo realizados com o objetivo de promover incremento no estoque de carbono no solo, a partir do sequestro de carbono atmosférico pelo processo fotossintético e sua adição ao solo por intermédio da estabilização da MO.

\subsubsection{Fracionamento físico granulométrico da matéria orgânica do solo}

A influência positiva da MO sobre os atributos do solo está ligada às suas diversas frações, que estão localizadas em diferentes compartimentos, possuindo 
diferentes tempos de reciclagem e formas de proteção (Duxbury et al., 1989). Essas frações podem ser diferenciadas a partir de inúmeras técnicas de determinação e possuem como uma das finalidades avaliar alterações provocadas pelas práticas agrícolas (Roscoe \& Buurman, 2003).

Entre os diversos procedimentos para separar frações da MO, o fracionamento físico granulométrico permite a obtenção de frações orgânicas associadas à granulometria do solo (Cambardella \& Elliott, 1992). Pelo procedimento destes autores, é possível quantificar os teores de carbono orgânico com tamanho da fração areia (diâmetro $\geq 53 \mu \mathrm{m}$ ), denominado de carbono orgânico particulado (CP) e o carbono associado às frações silte e argila $(\mathrm{CM})$ (diâmetro $<53 \mu \mathrm{m})$.

O CP é encontrado normalmente na MO que está no início do processo de decomposição, mantendo características identificáveis do material de origem. Dessa forma é composta de material facilmente mineralizável pela população microbiana do solo, ou seja, de maior labilidade (Duxbury et al., 1989). Esta fração pode se apresentar protegida pelos macroagregados ou livre, fora de agregados (Zinn et al., 2007). Portanto, respondem mais rapidamente às mudanças provocadas pelo manejo do solo, quando comparadas ao teor de CM.

Dessa forma, o teor de CP é influenciado pela quantidade e qualidade dos resíduos depositados, sendo que culturas que possuem elevado aporte de biomassa favorecem o aumento de CP (Rossi et al., 2012; Loss et al., 2014). Em virtude das características apresentadas, o CP vem sendo utilizado como indicador do balanço de carbono no solo, devido a sua elevada sensibilidade as alterações relacionadas ao manejo do solo (Figueiredo et al., 2010; Nunes et al., 2011; Coser et al., 2012).

O CM apresenta maior estabilidade no solo quando comparado ao CP. Essa estabilidade está associada ao avançado estágio de humificação, interação com a fração mineral do solo e também devido à proteção física proporcionada pela localização no interior dos microagregados (Bayer et al., 1996). Dessa forma, essa fração responde pelo estoque de C de médio e longo prazo de permanência no solo (Salton et al., 2005).

Adicionalmente o CM possui uma ciclagem lenta ocasionada pelo seu processo de formação e, para que ocorram mudanças nessa fração, são requeridos maiores períodos de manejo no solo (Bayer et al., 2004). Portanto, o CM ocorre em proporções superiores em relação ao CP, conforme observado por Bayer et al. (2009), onde de 91 a 93\% do $\mathrm{C}$ total do solo na camada de $0-20 \mathrm{~cm}$ estava na fração CM. Além disso, maiores teores de CM são observados em solos argilosos (Zinn et al., 2007). 
O conhecimento das diferentes frações da $\mathrm{MO}$ auxilia no adequado manejo dos sistemas agrícolas, possibilitando a adoção de práticas que favoreçam a elevação dos teores de MO. Além de proporcionar uma condição favorável para a fertilidade do solo, representa uma forma de reduzir a emissão de $\mathrm{CO}_{2}$ na agricultura.

\subsubsection{Estoque de carbono no solo e os sistemas agrícolas}

O estoque de carbono no solo é cerca de 3,3 vezes maior que o contido na atmosfera, sendo que $62 \%$ desse estoque é composto de carbono orgânico, representando $1550 \mathrm{Gt}$ (Lal, 2004). Assim, a agricultura exerce papel fundamental no ciclo do carbono, devido às alterações provocadas nos teores de $\mathrm{MO}$, principal constituinte do estoque de carbono do solo.

O estoque de carbono orgânico no solo $(\mathrm{CO})$ sofre influência de fatores climáticos (Lal, 2005) e propriedades do solo, como textura, mineralogia e estrutura (Zinn et al., 2005; Grüneberg et al., 2010). Adicionalmente, o manejo dos sistemas agrícolas exerce influência direta no estoque de $\mathrm{CO}$, seja a partir de alterações nas propriedades do solo ou através do fornecimento de biomassa vegetal. Assim, manejos agrícolas que favoreçam a manutenção da estrutura do solo e o aporte de biomassa aérea e radicular possuem a capacidade de sequestrar carbono atmosférico e consequentemente elevar o estoque de CO (Bayer et al., 2006; Carvalho et al., 2009).

O aporte de biomassa vegetal pelas culturas está dentre os principais mecanismos que proporciona o aumento do estoque de CO no solo principalmente pelo sistema radicular, que favorece a adição de carbono em profundidade (Lovato et al., 2004; d'Andréa et al., 2004; Vezzani \& Mielniczuk et al., 2011).

Segundo Rasse et al. (2005), o CO é favorecido pelo sistema radicular em maior proporção que a parte aérea devido aos mecanismos de proteção físicos e químicos, através dos agregados e também pela presença de compostos de maior recalcitrância nos tecidos radiculares. Dessa forma, tecnologias que promovam elevação na proporção raiz/parte aérea contribuiriam a maior permanência no solo do carbono assimilado através das culturas, elevando o CO no solo.

\subsubsection{Efeito do gesso sobre a matéria orgânica do solo}

Com a aplicação de gesso em sistemas agrícolas e as alterações ocasionadas nas propriedades físicas e químicas do solo, como consequência do fornecimento de 
nutrientes e a correção da toxidez de alumínio em profundidade, são benefícios consolidados para o manejo dos sistemas agrícolas. No entanto, são escassas as pesquisas sobre a influência desses atributos na dinâmica da $\mathrm{MO}$ e nos estoques de carbono do solo.

Um efeito indireto do uso do gesso na dinâmica da MO seria a ação do cálcio na formação de complexos organominerais (argila-MO) através de ponte catiônica em solos com o predomínio argilominerias de alta atividade (2:1) (Six et al., 2004; Bronick \& Lal, 2005). Desse modo, ocorre maior estabilização da MO, proporcionando maior tempo de permanência no solo através da proteção física conferida pela formação de agregados.

O efeito do gesso como condicionador do solo para o crescimento radicular pode desempenhar importante função no incremento de MO através do aporte de resíduos orgânicos em profundidade. Sabe-se que em torno de 27 a $37 \%$ da entrada de carbono no solo tem origem nas raízes (Santos et al., 2011).

O aumento da agregação do solo pela aplicação de gesso favoreceu maiores teores de MO a partir da combinação de doses de gesso e calcário (Rosa Junior et al., 2007). Contribuição semelhante foi encontrada por Ferreira et al. (2012) verificando aumento no conteúdo de carbono até a profundidade de 0-40 cm no solo em comparação com o tratamento sem gesso. Dessa forma, torna-se evidente a importância da aplicação de gesso como condicionador de ambiente radicular e o seu potencial para contribuir com aumento do estoque de carbono no solo. 


\section{REFERÊNCIAS BIBLIOGRÁFICAS}

AMARAL, A.S. \& ANGHINONI, I. Alteração de parâmetros químicos do solo pela reaplicação superficial de calcário no sistema plantio direto. Pesquisa Agropecuária Brasileira, Brasília, v.36, n.4, p.695-702, 2001.

ASSAD, E.D.; SANO, E.E.; MASUTOMO, R.; CASTRO, L.H.R.; SILVA, F.A.M. Veranicos na região dos Cerrados brasileiros frequência e probabilidade de ocorrência. Pesquisa Agropecuária Brasileira, Brasília, v.28, n.9, p.993-1003, 1993.

BAYER, C. Dinâmica da matéria orgânica em sistemas de manejo de solos. 1996. 241p. Tese (Doutorado) - Universidade Federal do Rio Grande do Sul, Porto Alegre, 1996.

BAYER, C.; MARTIN-NETO, L.; MIELNICZUK, J.; PAVINATO, A. Armazenamento de carbono em frações lábeis da matéria orgânica de um Latossolo Vermelho sob plantio direto. Pesquisa Agropecuária Brasileira, Brasília, v.39, n.7, p.677-683, 2004.

BAYER, C.; MARTIN-NETO, L.; MIELNICZUK, J.; PAVINATO, A.; DIECKOW, J. Carbon sequestration in two Brazilian Cerrado soils under no-till. Soil and Tillage Research, Amsterdam, v.86, n.2, p.237-245, 2006.

BAYER, C.; DIECKOW, J.; AMADO, T.J.C.; ELTZ, F.L.F. \& VIEIRA, F.C.B. Cover crop effects increasing carbon storage in a subtropical no-till sandy Acrisol. Communications in Soil Science and Plant Analysis, Reino Unido, v.40, n.9-10, p.1499-1511, 2009.

BORGES, E.N.; LOMBARDI NETO, F.; CORREAA, G.F.; COSTA, L.M. Misturas de gesso e matéria orgânica alterando atributos físicos de um Latossolo com compactação simulada. Revista Brasileira de Ciência do Solo, Viçosa, v.21, n.1, p.125-130, 1997.

BRAIDA, J.A.; REICHERT, J.M.; VEIGA, M.; REINERT J.D. Resíduos vegetais na superfície e carbono orgânico do solo e suas relações com a densidade máxima obtida no ensaio Proctor. Revista Brasileira de Ciência do Solo, Viçosa, v.30, n.4, p.605-614, 2006.

BRAIDA, J.A.; REICHERT, J.M.; REINERT, D.J.; VEIGA, M.D. Teor de carbono orgânico e a susceptibilidade à compactação de um Nitossolo e um Argissolo. Revista 
Brasileira de Engenharia Agrícola e Ambiental, Campina Grande, v.14, n.2, p.131$139,2010$.

BRONICK, C.J. \& LAL, R. Soil structure and management: a review. Geoderma, Amsterdam, v.124, n.1, p.3-22, 2005.

CAIRES, E.F.; FELDHAUS, I.C.; BLUM, J. Crescimento radicular e nutrição da cevada em função da calagem e aplicação de gesso. Bragantia, Campinas, v.60, n.3, p.213-223, 2001.

CAIRES, E.F.; FELDHAUS, I.C.; BARTH, G.; GARBUIO, F.J. Lime and gypsum application on the wheat crop. Scientia Agrícola, Piracicaba, v.59, n.2, p.357-364, 2002.

CAIRES, E.F.; KUSMAN, M.T.; BARTH, G.; GARBUIO, F.J.; PADILHA, J.M. Alterações químicas do solo e resposta do milho à calagem e aplicação de gesso. Revista Brasileira de Ciência do Solo, Viçosa, v.28, n.1, p.125-136, 2004.

CAIRES, E.F.; CHURKA, S.; GARBUIO, F.J.; FERRARI, R.A.; MORGANO, M.A. Soybean yield and quality as a function of lime and gypsum applications. Scientia Agrícola, Piracicaba, v.63, n.4, p.370-379, 2006.

CALAÇA, M. \& DIAS, W.A. A modernização do campo no cerrado e as transformações socioespaciais em Goiás. CAMPO-TERRITÓRIO: revista de geografia agrária, Uberlândia, v.5, n.10, p.312-332, 2010.

CAMBARDELLA, C.A. \& ELLIOTT, E.T. Particulate soil organic-matter changes across a grassland cultivation sequence. Soil Science Society of America Journal, Madison, v.56, n.3, p.777-783, 1992.

CAMPBELL, C.A. Soil organic carbon, nitrogen and fertility. In: SCHINITZER, M. \& KHAN, S.U. (Ed.). Soil organic matter. Elsevier Amsterdam, 1978. p.173-271.

CARDUCCI, C.E.; OLIVEIRA, G.C.; CURI, N.; SEVERIANO, E.C.; ZEVIANI, W.M. Relations of Clay Fraction Mineralogy, Structure and Water Retention in Oxidic Latosols (Oxisols) from the Brazilian Cerrado Biome. In: VALAŠKOVA, M. \& MARTYNKOVA, G.S. (Eds.). Clay minerals in nature: their characterization, modification and application. ISBN 978-953-51-0738-5, 2012.

CARNEIRO, M.A.C.; SOUZA, E.D.; REIS, E.D.; PEREIRA, H.S; AZEVEDO, W. D. Atributos físicos, químicos e biológicos de solo de cerrado sob diferentes sistemas de 
uso e manejo. Revista Brasileira de Ciência do Solo, Viçosa, v.33, n.1, p.147-157, 2009.

CARVALHO, J.L.N.; CERRI, C.E.P.; FEIGL, B.J.; PICCOLO, M.C.; GODINHO, V.P.; CERRI, C.C. Carbon sequestration in agricultural soils in the Cerrado region of the Brazilian Amazon. Soil and Tillage Research, Amsterdam, v.103, n.2, p.342-349, 2009.

CASTRO, W.J.; LEMKE-DE-CASTRO, M.L.; LIMA, J.O.; OLIVEIRA, L.F.C.; RODRIGUES, C.; FIGUEIREDO, C.C. Erodibilidade de Solos do Cerrado Goiano. Revista em Agronegócio e Meio Ambiente, Maringá, v.4, n.2, p.305-320, 2011.

CHAVES, A.A.A., LACERDA, M.P.C.; GOEDERT, W.J.; RAMOS, M.L.G.; KATO, E. Indicadores de qualidade de Latossolo Vermelho sob diferentes usos. Pesquisa Agropecuária Tropical, Goiânia, v.42, n.4, p.446-454, 2012.

CIOTTA, M.N.; BAYER, C.; FONTOURA, S.M.V.; ERNANI, P.R; ALBUQUERQUE, J.A. Matéria orgânica do solo e aumento da capacidade de troca de cátions em solo com argila de atividade baixa sob sistema plantio direto. Ciência Rural, Santa Maria, v.33, n.6, p.1161-1164, 2003.

COCHRANE, T.T. PORRAS, J.A.; HENAO, M.R. The relative tendency of the Cerrados to be affected by veranicos. A provisional assessment. In: SIMPÓSIO SOBRE O CERRADO, 6, 1982, Brasília. Anais... Planaltina: EMBRAPA-CPAC, 1988. p. 229238.

COCHRANE, T.T. \& AZEVEDO, L.G. As savanas do trópico sul-americano; uma visão geral dos seus recursos de clima e solo para desenvolvimento agrotecnológico baseada no inventário computadorizado de sistemas de terra do CIAT/EMBRAPA. In: SIMPÓSIO SOBRE O CERRADO, 6., Brasília, 1982. Savanas: alimento e energia. Brasília, EMBRAPA-DDT, 1988, Prelo.

COMPANHIA NACIONAL DE ABASTECIMENTO - CONAB. Séries Históricas Cana-de-açucar Relativas às Safras 2005/06 a 2014/15 de Área Plantada, Produtividade, Produção, Áçucar, Etanol total, Etanol anidro e Etanol hidratado. Disponível em: <http://www.conab.gov.br/conteudos.php?a=1252\&t=\&Pagina_objcmsconteudos=2\#A _objcmsconteudos >. Acesso em: 10 de Janeiro, 2015. 
COMPANHIA NACIONAL DE ABASTECIMENTO - CONAB. Séries Históricas Milho Relativas às Safras 1976/77 a 2014/15 de Área, Produtividade, Produção. Disponível em: <http://www.conab.gov.br/conteudos.php?a=1252\&\&Pagina_objcmsconteudos=3\#A_o bjcmsconteudos>. Acesso em: 29 de Janeiro, 2015.

COMPANHIA NACIONAL DE ABASTECIMENTO - CONAB. Séries Históricas Soja Relativas às Safras 1976/77 a 2014/15 de Área, Produtividade, Produção. Disponível em: $<$ http://www.conab.gov.br/conteudos.php?a=1252\&t=\&Pagina_objcmsconteudos=3\#A _objcmsconteudos>. Acesso em: 29 de Janeiro, 2015.

COMPANHIA NACIONAL DE ABASTECIMENTO - CONAB. Acompanhamento da Safra Brasileira de Grãos. Disponível em: $<$ http://www.conab.gov.br/conteudos.php?a=1253\&t=\&Pagina_objcmsconteudos=17\# A_objcmsconteudos>. Acesso em: 29 de Janeiro, 2015.

CONCEIÇÃO, P.C.; AMADO, T.J.C.; MIELNICZUK, J.; SPAGNOLLO, E. Qualidade do solo em sistemas de manejo avaliada pela dinâmica da matéria orgânica e atributos relacionados. Revista Brasileira de Ciência do Solo, Viçosa, v.9, n.5, p.777-788, 2005. COSER, T.R.; FIGUEIREDO, C.C.; RAMOS, M.L.G.; JANNUZZI, H.; MARCHÃO, R.L. Recuperação de carbono obtida por três métodos em frações da matéria orgânica de Latossolo, sob consórcio milho-forrageiras, no Cerrado. Bioscience Journal, Uberlândia, v.28, n.1, p. 91-97, 2012.

COSTA, A.R.D.; SATO, J.H.; RAMOS, M.L.G.; FIGUEIREDO, C.C.; SOUZA, G.P.D.; ROCHA, O.C.; GUERRA, A.F. Microbiological properties and oxidizable organic carbon fractions of an oxisol under coffee with split phosphorus applications and irrigation regimes. Revista Brasileira de Ciência do Solo, Viçosa, v.37, n.1, p.5565, 2013.

COSTA, F.S.; ALBUQUERQUE, J.A.; BAYER, C.; FONTOURA, S.M.V.; WOBETO, C. Propriedades físicas de um Latossolo Bruno afetadas pelos sistemas plantio direto e preparo convencional. Revista Brasileira de Ciência do Solo, Viçosa, v.27, p.527-535, 2003. 
CRUZ, T.V.D.; PEIXOTO, C.P.; MARTINS, M.C. Crescimento e produtividade de soja em diferentes épocas de semeadura no Oeste da Bahia. Scientia Agraria, Piracicaba, v.11, n.1, p.033-042, 2010.

CUSTÓDIO, D.P.; OLIVEIRA, I.P.D.; COSTA, K.A.D.P.; SANTOS, R.S.M.; FARIA, C.D. Avaliação do gesso no desenvolvimento e produção do capim-tanzânia. Ciência Animal Brasileira, Goiânia, v.6, n.1, p.27-34, 2006.

DAMICO, F.S. \& NASSAR, A.M. 2007. Agricultural expansion and policies in Brazil. In: US Agricultural Policy and the 2007 Farm Bill. Woods Institute for the Environmentat Stanford University, Stanford, p.75-96.

D'ANDRÉA, A.F.; SILVA, M.L.N.; CURI, N.; GUILHERME, L.R.G. Estoque de carbono e nitrogênio e formas de nitrogênio mineral em um solo submetido a diferentes sistemas de manejo. Pesquisa Agropecuária Brasileira, Brasília, v.39, n.2, p.179-186, 2004.

DEMATTÊ, J.L.I.; PAGGIARO, C.M.; BELTRAME, J.A.; RIBEIRO, S.S. Uso de silicatos em cana-de-açúcar. Informações Agronômicas, n.133, p.7-12, 2011.

DUXBURY, J.M.; SMITH, M.S.; DORAN, J.W. Soil organic matter as a source and sink of plant nutrients. In: COLEMAN, D.C.; OADES, J.M. \& UEHARA, G. (Eds.). Dynamics of soil organic matter in tropical ecosystems. Honolulu: University of Hawaii Press, 1989.

EMBRAPA. Relatório de avaliação dos impactos das tecnologias geradas pela EMBRAPA - 2013. Disponível em:< http://www.embrapa.br >. Acessado 02 Fevereiro, 2014.

ERNANI, P.R.; RIBEIRO, M.S.; BAYER, C. Modificações químicas em solos ácidos ocasionadas pelo método de aplicação de corretivos da acidez e de gesso agrícola. Scientia Agrícola, Piracicaba, v.58, n.4, p.825-831, 2001.

Food and Agricultural Organization of the United Nations - FAOSTAT 2012. Disponível em: <http://faostat.fao.org/site/339/default.aspx>. Acesso em: 03 de Janeiro 2015.

FAVARETTO, N.; NORTON, L.D.; JOERN, B.C. BROUDER, S.M. Gypsum amendment and exchangeable calcium and magnesium affecting phosphorus and 
nitrogen in runoff. Soil Science Society of American Journal, Madison, v.70, n.5, p.1788-1796, 2006.

FERREIRA, A.O.; SÁ, J.C.M.; HARMS, M.G.; MIARA, S.; BRIEDIS, C.; QUADROS NETTO, C.; SANTOS, J.B.; CANALLI, L.B.S; DIAS, C.T.S. Relação de estratificação como indicador do sequestro de carbono em macroagregados de Latossolo sob plantio direto. Ciência Rural, Santa Maria, v.42, n.4, p.645-652, 2012.

FIGUEIREDO, C.C.; RESCK, D.V.S.; CARNEIRO, M.A.C. Labile and stable fractions of soil organic matter under management systems and native Cerrado. Revista Brasileira de Ciência do Solo, Viçosa, v.34, n.3, p.907-916, 2010.

FRANCHINI, J.C.; DEBIAS, H.; SACOMAN, A.; NEPOMUCENO, A.L.; FARIAS, J.R.B. Manejo do solo para redução das perdas de produtividade pela seca. Embrapa Soja, Londrina, 2009.

GRÜNEBERG, E.; SCHÖNING, I.; KALKO, E.K.; WEISSER, W.W. Regional organic carbon stock variability: A comparison between depth increments and soil horizons. Geoderma, Amsterdam, v.155, n.3, p.426-433, 2010.

GUELFI, D.R.; FAQUIN, V.; SOUZA, M.A.S.; OLIVEIRA, G.C.; SANTOUCY, S.G.; BASTOS, C.E.A. Características estruturais e produtivas do capim-marandu sob efeitos de corretivos da acidez, gesso e compactação do solo. Interciencia, Venezuela, v.38, n.9, p.681-687, 2013.

GOLDEMBERG, J. Biomassa e energia. Química Nova, São Paulo, v.32, n.3, p.582$587,2009$.

GUIMARÃES, P.T.G.O. Uso do gesso na cultura do cafeeiro. In: SEMINÁRIO SOBRE O USO DO GESSO NA AGRICULTURA, 2. Anais... Uberaba, 1992.

HERNANDES, T.A.D., BUFON, V.B.; SEABRA, J.E. Water footprint of biofuels in Brazil: assessing regional differences. Biofuels, Bioproducts and Biorefining, v.8, n.2, p.241-252, 2014.

LAL, R. Soil carbon sequestration to mitigate climate change. Geoderma, Amsterdam, v.123, n.1, p.1-22, 2004.

LAL, R. Forest soils and carbon sequestration. Forest Ecology Management, Canadá, v.220, n.1, p.242-258, 2005. 
LOPES, A.S. \& COX, F.R. A survey of the fertility status of surface soil under "Cerrado" vegetation in Brazil. Soil Science Society of America Journal, Madison, v.41, n.4, p.742-747, 1977.

LOPES, A.S.; GUIMARÃES, G.L.R.; RAMOS, S.J. The Saga of the Agricultural Development of the Brazilian Cerrado. International Potash Institute. n.32, p.29-37, 2012.

LORENZETTI, J.M.; RODRIGUES, J.C.; MORALES, S.H.; DEMATTÉ, J.L.I. Uso de calcário e gesso em soqueira de cana-de-açúcar. STAB, Piracicaba, v.10, p.14-18, 1992. LOSS, A.; PEREIRA, M.G.; COSTA, E.M.; BEUTLER, S.J. Frações granulométricas e oxidáveis da matéria orgânica sob diferentes sistemas de uso do solo, no Paraná, Brasil. Bioscience Journal, Uberlândia, v.30, n.1, p.43-54, 2014.

LOVATO, T.; MIELNICZUK, J.; BAYER, C.; VEZZANI, F. Adição de carbono e nitrogênio e sua relação com os estoques no solo e com o rendimento do milho em sistemas de manejo. Revista Brasileira de Ciência do Solo, Viçosa, v.28, n.1, p.175$187,2004$.

MACEDO, J. Os solos da região dos Cerrados. In: ALVARES, V.V.H.; FONTES, L.E.F.; FONTES, M.P.F. (Eds.). O solo nos grandes Domínios Morfoclimáticos do Brasil e o desenvolvimento sustentado. Viçosa, 1996. p.135-155.

MACEDO, I.C.; SEABRA, J.E.A.; SILVA, J. Green house gases emissions in the production and use of ethanol from sugarcane in Brazil: The 2005/2006 averages and a prediction for 2020. Biomass and bioenergy, Reino Unido, v.32, n.7, p.582-595, 2008.

MALAVOLTA, E. ABC da análise de solo e folhas: amostragem, interpretação e sugestões de adubação. São Paulo: Ed. Agronômica Ceres, 1992. 124p.

Ministério da Ciência, Tecnologia e Inovação - MCTI. Estimativas anuais de emissões de gases de efeito estufa no Brasil 2013. Disponível em: < http://gvces.com.br/arquivos/177/EstimativasClima.pdf >. Acesso em: 04 de dezembro, 2014.

MENEZES, H.E.; BRITO, J.I.B.; LIMA, R.A.F.A. Veranico e a produção agrícola no Estado da Paraíba, Brasil. Revista Brasileira de Engenharia Agrícola e Ambiental, Campina Grande, v.14, n.2, p.181-186, 2010. 
MESQUITA, E.E.; FONSECA, D.D.; NASCIMENTO JUNIOR, D.D., PEREIRA, O.G.; PINTO, J.C. Efeitos de métodos de estabelecimento de braquiária e estilosantes e de doses de calcário, fósforo e gesso sobre alguns componentes nutricionais da forragem. Revista Brasileira de Zootecnia, Viçosa, v.31, n.6, p.2186-2196, 2002.

MIKHA, M.M. \& RICE, C.W. Tillage and manure effects on soil and aggregateassociated carbon and nitrogen. Soil Science Society of America Journal, Madison, v.68, n.3, p.809-816, 2004.

MIRANDA, H. Expansão da agricultura e sua vinculação com o processo de urbanização na Região Nordeste/Brasil (1990-2010). Revista Latino-americana de Estúdios Urbano Regionales, Santiago, v.38, n.114, p.173-201, 2012.

MOLINA, J.A.E.; CLAPP, C.E.; LINDEN, D.R.; ALLMARAS, R.R.; LAYESE, M.F.; DOWDY, R.H; CHENG, H.H. Modeling the incorporation of corn (Zea mays L.) carbon from roots and rhizodeposition into soil organic matter. Soil Biology and Biochemistry, Heidelberg, v.33, n.1, p.83-92, 2001.

NUNES, R.S. de; LOPES, A.A.C. de; SOUSA, D.M.G. de; MENDES, I.C. de. Sistemas de manejo e os estoques de carbono e nitrogênio em Latossolo de Cerrado com a sucessão soja-milho. Revista Brasileira de Ciência do Solo, Viçosa, v.35, n.4, p.14071419, 2011.

OLIVEIRA, I.P.; COSTA, K.A.P. de; FAQUIN, V., MACIEL, G.A.; NEVES, B.P.; MACHADO, E.L. Efeitos de fontes de cálcio no desenvolvimento de gramíneas solteiras e consorciadas. Ciência e Agrotecnologia. Lavras, v.33, n.2, p.592-598, 2009. OLIVEIRA, F.M.C., BORGES, L.E.P., MELO, E.B.de; BARROS, M.L.S.C. Características mineralógicas e cristalográficas da gipsita do Araripe. HOLOS, Natal, v.5, p.71-82, 2012.

PAPA, R.A.; LACERDA, M.P.C.; CAMPOS, P.M.; GOEDERT, W.J.; RAMOS, M.L.G.; KATO, E. Qualidade de Latossolos Vermelhos e Vermelho-Amarelos sob vegetação nativa de Cerrado. Pesquisa Agropecuária Tropical, Goiânia v.41, n.4, p.564-571, 2011.

RAIJ, B. V. Gesso na agricultura. Campinas: Instituto Agronômico, 2008a. p. 12-23.

RAMOS, B.Z.; TOLEDO, J.P.V.F.; LIMA, J.M.D.; SERAFIM, M.E.; BASTOS, A.R.R.; GUIMARÃES, P.T.G.; COSCIONE, A.R. Gypsum applications to coffe: 
influence on calcium, magnesium and potassium contents and $\mathrm{pH}$ of the solution of a dystrophic Red Latosol. Revista Brasileira de Ciência do Solo, Viçosa, v.37, n.4, p.1018-1026, 2013.

RAMPIM, L.; LANA, M.C.; FRANDOLOSO, J.F. Fósforo e enxofre disponível, alumínio trocável e fósforo remanescente em Latossolo Vermelho submetido ao gesso cultivado com trigo e soja. Semina: Ciências Agrárias, Londrina, v.34, n.4, p.1623$1638,2013$.

RASSE, D.P.; CORNELIA R.; DIGNAC, M.F. Is soil carbon mostly root carbon? Mechanisms for a specific stabilisation. Plant and Soil, Dordrecht, v.269, n.1-2, p.341$356,2005$.

RESCK, D.V.S.; FERREIRA, E.A.B.; FIGUEIREDO, C.C.; ZINN, Y.L. Dinâmica da matéria orgânica no Cerrado. In: SANTOS, G.A.; SILVA, L.S.; CANELLAS, L.P. \& CAMARGO, F.O., Fundamentos da matéria orgânica do solo: Ecossistemas tropicais e subtropicais. 2.ed. Porto Alegre, Metrópole, 2008. p.359-417.

RHEINHEIMER, D.S.; SANTOS, E.J.S.; KAMINSKI, J.; BORTOLUZZI, E.E.; GATIBONI, L.C. Alterações de atributos do solo pela calagem superficial e incorporada a partir de pastagem natural. Revista Brasileira de Ciência do Solo, Viçosa, v.24, p.797-805, 2000.

RITCHEY, K.D.; SOUSA, D.M.G.; LOBATO, E.; CORREA, O. Calcium leaching to increase rooting depth in Brazilian savannanh oxisol. Agronomy Journal, Madison, v.72, n.1, p.40-44, 1980.

RITCHEY, K.D.; SILVA, J.E.; COSTA, U.F. Calcium deficiency in clayey B horizons of savanna oxisols. Soil Science, Ottawa, v.133, n.6, p.378-382, 1982.

ROCHA, A.T.; OLIVEIRA, A.C.; RODRIGUES, Á.N.; LIRA JÚNIOR, M.A.; FREIRE, F.J. Emprego do gesso do Araripe na melhoria do ambiente radicular da canade-açúcar, Revista Brasileira de Ciências Agrárias, Pernambuco, v.3, n.4, p.307-312, 2008.

ROCHA, M. Difusão do uso agrícola do fosfato. In: I Seminário sobre o Uso de Fosfogesso na Agricultura. Anais... IBAFOS, Brasília, 1985. 
ROSA JUNIOR, E.J.; MARTINS, R.M.G.; ROSA, Y.B.C.J.; CREMON, C. Calcário e gesso como condicionantes físico e químico de um solo de cerrado sob três sistemas de manejo. Pesquisa Agropecuária Tropical, Goiânia, v.36, n.1, p.37-44, 2007.

ROSCOE, R. \& BUURMAN, P. Tillage effects on soil organic matter in density fractions of a Cerrado Oxisol. Soil and Tillage Research, Amsterdam, v.70, n.2, p.107$119,2003$.

ROSSI, C.Q., PEREIRA, M.G., GIÁCOMO, S.G., BETTA, M.; POLIDORO, J.C. Frações lábeis da matéria orgânica em sistema de cultivo com palha de braquiária e sorgo. Revista Ciência Agronômica, Fortaleza, v.43, n.1, p.38-46, 2012.

SÁ, P.C.C. de; DO VALE, C.N.C.; MAIA, C.E.; LEVIEN, S.L.A. Índices e área sob a curva de retenção de água para avaliar qualidade física do solo. Revista Brasileira de Agricultura Irrigada, Fortaleza, v.4, n.2, p.110-114, 2010.

SANO, E.E.; ROSA, R.; BRITO, J.L.S.; FERREIRA, L.G. Notas Científicas Mapeamento semidetalhado do uso da terra do Bioma Cerrado. Pesquisa Agropecuária Brasileira, Brasília, v.43, n.1, p.153-156, 2008.

SALDANHA, E.C.M.; ROCHA, A.T.; OLIVEIRA, E.C.A.; DO NASCIMENTO, C.W.A.; FREIRE, F.J. Uso do gesso mineral em Latossolo cultivado com cana-deaçúcar. Revista Caatinga, Mossoró, v.20, n.1, p.36-42, 2007.

SANTOS, N.Z.; DIECKOW, J.; BAYER, C.; MOLIN, R.; FAVARETTO, N.; PAULETTI, V.; PIVA, J.T. Forages, cover crops and related shoot and root additions in no-till rotations to $\mathrm{C}$ sequestration in a subtropical Ferralsol. Soil \& Tillage Research, Amsterdam, v.111, n.2, p.208-218, 2011.

SANTOS, F.A.; QUEIRÓZ, J.D.; COLODETTE, J.L.; FERNANDES, S.A.; GUIMARÃES, V.M.; REZENDE, S.T. Potencial da palha de cana-de-açúcar para produção de etanol. Química Nova, São Paulo, v.35, n.5, p.1004-1010, 2012.

SANTOS, R.L.; FREIRE, F.J.; AZEVEDO, V.M.; ROCHA, A.T.; TAVARES, J.A. Produção de capim elefante e movimentação de cátions em função de gesso mineral. Revista Brasileira de Engenharia Agrícola e Ambiental, Campina Grande, v.17, n.10, p.1030-1037, 2013.

SAlTON, J. C.; MIELNICZUK, J.; BAYER, C.; FABRICIO, A. C.; MACEDO, M. C. M.; BROCH, D. L.; BOENI, M.; CONCEIÇÃO, P. C. Matéria orgânica do solo na 
integração lavoura-pecuária em Mato Grosso do Sul. Dourados: Embrapa Agropecuária Oeste, 2005. 58 p. (Embrapa Agropecuária Oeste, Boletim de Pesquisa e Desenvolvimento, 29).

SERAFIM, M.E., DE LIMA, J.M., LIMA, V.M.P., ZEVIANI, W.M.; PESSONI, P.T. Alterações físico-químicas e movimentação de íons em Latossolo gibbsítico sob doses de gesso. Bragantia, Campinas, v.71, n.1, p.75-81, 2012.

SILVA, C.A.; MELO, L.C.A.; RANGEL, O.J.P.; GUIMARÃES, P.T.G. Coffee yield and fertility attributes of a latosol under influence of population density and liming management. Ciência e Agrotecnologia, Lavras, v.28, n.5, p.1066-1076, 2004.

SILVA, C.R. da; SOUZA, K.B. de; FURTADO, W.F. Evaluation of the Progress of Intensive Agriculture in the Cerrado Piauiense-Brazil. IERI Procedia, v.5, p.51-58, 2013.

SIGNOR, D.; ZANI, C.F., PALADINI, A.A.; DALL'IGNA, M. Estoques de carbono e qualidade da matéria orgânica do solo em áreas cultivadas com cana-de-açúcar. Revista Brasileira de Ciência do Solo, Viçosa, v.38, n.5, p.1402-1410, 2014.

SIX, J.; BOSSUYT, H.; DEGRYZE, S; DENEF, K. A history of research on the link between (micro) aggregates, soil biota, and soil organic matter dynamics. Soil and Tillage Research, Amsterdam, 79:7-31, 2004.

SOBRAL, L.F.; CINTRA, F.L.D.; SMYTH, T.J. Lime and gypsum to improve root depth of orange crop in an Ultisol of the Coastal Tablelands. Revista Brasileira de Engenharia Agrícola e Ambiental. Campina Grande, v.13, p.836-839, 2009.

SORATTO, R.P. \& CRUSCIOL, C.A.C. Cátions hidrossolúveis na parte aérea de culturas anuais mediante aplicação de calcário e gesso em superfície. Revista Brasileira de Ciência do Solo, Viçosa, v.31, p.81-90, 2007.

SORATTO, R.P. \& CRUSCIOL, C.A.C. Produção de fitomassa e acúmulo de nutrientes pela aveia-preta em função da aplicação de calcário e gesso em superfície na implantação do sistema plantio direto. Ciência Rural, Santa Maria, v.38, n.4, p.928935, 2008.

SORATTO, R.P., CRUSCIOL, C.A.C.; MELlO, F. Componentes da produção e produtividade de cultivares de arroz e feijão em função de calcário e gesso aplicados na superfície do solo. Bragantia, Campinas, v.69, n.4, p.965-974, 2010. 
SOUSA, D.M.G. de; REIN, T.R.; LOBATO, E.; RITCHEY, K.D. Sugestões para a diagnose e recomendação de gesso em solos de Cerrado. In: SEMINÁRIO SOBRE O USO DO GESSO NA AGRICULTURA, 2. 1992, Anais... Uberaba. São Paulo: IBRAFOS, 1992. p. 139-158.

SOUSA, D.M.G.; VILELA, L.; LOBATO, E.; SOARES, W.V. Uso de gesso, calcário e adubos para pastagens no Cerrado. Embrapa Cerrados. Circular Técnica, v. 12, 2001.

SOUSA, D.M.G. \& LOBATO, E. Adubação fosfatada em solos da região do Cerrado. Piracicaba, Potafos, 2003. 16p. (Informações Agronômicas, 102)

SOUSA, D.M.G. \& LOBATO, E. Cerrado: correção do solo e adubação. Planaltina: Embrapa Cerrados, 2004.

SOUSA, D.M.G. de; LOBATO, E.; REIN, T. A. Uso do gesso agrícola nos solos do Cerrado. Embrapa Cerrados. Circular Técnica, v. 32, 2004.

SOUSA, D.M.G. de; REIN, T.A.; ALBRECH, J.C. Resposta a gesso pela cultura do algodão cultivada em sistema de plantio direto em um Latossolo de Cerrado. In: SIMPÓSIO NACIONAL DO CERRADO, 9., 2008, Brasília, DF. Anais... Planaltina, DF: Embrapa Cerrados, 2008.

SOUSA, D.M.G. \& REIN, T.A. Manejo da fertilidade do solo para culturas anuais: experiências no cerrado. Informações Agronômicas, IPNI, Piracicaba, n.126, p.1-7, 2009.

SOUSA, D.M.G. \& REIN, T.A. Soil Fertility Evaluation and Control for Annual Crops in the Cerrado. Better Crops, p. 12, 2011.

SPEHAR, C.R.; Melhoramento da soja para as baixas latitudes dos Cerrados. Pesquisa Agropecuária Brasileira, Brasília, v.29, n.8, p.1167-1180, 1994.

SPEHAR, C.R. \& TRECENTI, R. Desempenho agronômico de espécies tradicionais e inovadoras da agricultura em semeadura de sucessão e entressafra no Cerrado do Planalto Central Brasileiro. Bioscience Journal, Uberlândia, v.27, n.1, p.102-111, 2011.

STEVENSON, F.J. \& COLE, M.A. Cycles of soil: carbon, nitrogen, phosphorus, sulfur, micronutrients. 2.ed. New York, John Wiley \& Sons, 1999. 427p. 
THOMAS R.J.; AYARZA M.; LOPES A.S. Management and conservation of acid soils in the Savannahs of Latin America: lessons from the agricultural development of the Brazilan Cerrados. In: Management and conservation of tropical acid soils for sustainable crop production, IAEA, Vienna, p. 5-29, 2000.

TISDALL, J.M. \& OADES, J.M. Organic matter and water stable aggregates in soils. Journal of Soil Science, Ottawa, v.33, n.2, p.141-163, 1982.

TORMENA, C.A.; FRIEDRICH, R.; PINTRO, J.C.; COSTA, A.C.S.; FIDALSKI, J. Propriedades físicas e taxa de estratificação de carbono orgânico num Latossolo Vermelho após dez anos sob dois sistemas de manejo. Revista Brasileira de Ciência do Solo, Viçosa, v.28, n.6, p.1023-1031, 2004.

VENDRAME, P.R.; BRITO, O.R.; GUIMARÃES, M.F.; MARTINS, É.S.; BECQUER, T. Fertility and acidity status of latossolos (oxisols) under pasture in the Brazilian Cerrado. Anais da Academia Brasileira de Ciências, v.82, n.4, p.1085-1094, 2010.

VEZZANI, F.M. \& MIELNICZUK, J. Agregação e estoque de carbono em Argissolo submetido a diferentes práticas de manejo agrícola. Revista Brasileira de Ciência do Solo, Viçosa, v.35, n.1, p.213-223, 2011.

VITTI, G.C.; MAZZA, J.A.; PEREIRA, H.S.; DEMATTÊ, J.L.I. Resultados experimentais do uso de gesso na agricultura - cana-de-açúcar. In: SEMINÁRIO SOBRE O USO DO GESSO NA AGRICULTURA, 2., 1992, Uberaba. Anais... Uberaba: Instituto Brasileiro do Fosfato, 1992. p. 191-224.

ZAMBROSI, F.C.B.; ALLEONI, L.R.F.; CAIRES, E.F. Aplicação de gesso agrícola e especiação iônica da solução de um Latossolo sob sistema plantio direto. Ciência Rural, Santa Maria, v.37, n.1, p.110-117, 2007

ZINN, Y.L.; LAL, R.; RESCK, D.V. Changes in soil organic carbon stocks under agriculture in Brazil. Soil and Tillage Research, Amsterdam v.84, n.1, p.28-40, 2005.

ZINN, Y.L.; LAL, R.; BIGHMAN, J.M. \& RESCK, D.V.S. Edaphic controls on soil organic carbon retention in the Brazilian Cerrado: Texture and mineralogy. Soil Science Society of America Journal, Madison, v.71, n.4, p.1204-1214, 2007.

WACLAWOVSKY, A.J.; SATO, P.M.; LEMBKE, C.G.; MOORE, P.H.; SOUZA, G.M. Sugarcane for bioenergy production: an assessment of yield and regulation of sucrose content. Plant Biotechnology Journal, v.8, n.3, p.263-276, 2010. 


\section{CAPÍTULO I}

USO DE GESSO E SUA INFLUÊNCIA NA PRODUTIVIDADE DE CANA-DEAÇÚCAR E ATRIBUTOS QUÍMICOS DE UM LATOSSOLO VERMELHO DO CERRADO 


\section{USO DE GESSO E SUA INFLUÊNCIA NA PRODUTIVIDADE DE CANA-DE-AÇÚCAR E ATRIBUTOS QUÍMICOS DE UM LATOSSOLO VERMELHO DO CERRADO}

\subsection{RESUMO}

Os solos do Cerrado apresentam em geral teores baixos de bases trocáveis e elevados de alumínio tóxico tanto em camadas superficiais quanto na subsuperfície. Essa condição, associada à estacionalidade climática e aos veranicos limita o desenvolvimento das culturas. Considerando a expansão da cana-de-açúcar nessa região e por se tratar de uma cultura com alto requerimento hídrico, tecnologias que maximizem o uso de água no solo permitindo obter maiores produtividades são necessárias. Portanto, o objetivo desse trabalho foi avaliar a influência do uso de gesso na produtividade de cana-de-açúcar em quatro ciclos de cultivo, como também alterações nos atributos químicos de um Latossolo Vermelho, após 59 meses da aplicação. O experimento foi conduzido numa área experimental localizada na Embrapa Cerrados, em Planaltina-DF. O delineamento experimental constituiu-se de blocos casualizados, com 4 repetições e dois tratamentos: testemunha $\left(0 \mathrm{Mg} \mathrm{ha}^{-1}\right)$ e dose recomendada $\left(5 \mathrm{Mg} \mathrm{ha}^{-1}\right)$. Aplicou-se o gesso a lanço na superfície do solo após o plantio da cana-de-açúcar na estação seca, em julho de 2009. A produtividade e qualidade tecnológica foram avaliadas na cana-planta e em três socas. Efetuou-se a coleta de solo após avaliação da terceira soca em sete camadas (0-5; 5-10; 10-20; 20-40; 40-60; 60-80 e 80-100 cm), para a determinação dos seguintes atributos químicos: $\mathrm{pH}$ em $\mathrm{H}_{2} \mathrm{O}$ e em $\mathrm{CaCl}_{2}$; alumínio trocável $\left(\mathrm{Al}^{3+}\right)$ bases trocáveis $\left(\mathrm{Ca}^{2+}, \mathrm{Mg}^{2+}\right.$ e $\left.\mathrm{K}^{+}\right)$, acidez potencial $(\mathrm{H}+\mathrm{Al})$; enxofre $\left(\mathrm{S}_{-} \mathrm{SO}_{4}{ }^{2-}\right)$ e matéria orgânica (MO) facilmente oxidável. O uso do gesso proporcionou aumento na produtividade de colmos e de açúcares redutores totais na cana planta e nas três socas, elevou os teores de $\mathrm{Ca}^{2+}, \mathrm{Mg}^{2+} \mathrm{e}$ $\mathrm{SO}_{4}{ }^{2-}$ e reduziu a saturação por alumínio nas camadas de $20-100 \mathrm{~cm}, 40-100 \mathrm{~cm}, 0-100$ $\mathrm{cm}$ e 40-100 cm, respectivamente. Além disso, o gesso também proporcionou maior acúmulo de MO e maiores valores da capacidade de troca catiônica na camada de 40$100 \mathrm{~cm}$.

Palavras-chave: enxofre, veranicos, saturação por alumínio, matéria orgânica 


\subsection{ABSTRACT}

Cerrado soils generally have low levels of exchangeable bases and high aluminum toxicity both in surface and subsurface layers. This condition associated with climate seasonality and dry spell can limit crop development. Considering the expansion of sugarcane in the Cerrado region and the high demand for water of this crop, technologies that optimize water use allowing higher yields are required. Therefore, the aim of this study was to evaluate the gypsum influence over sugarcane yield in four cycles of cultivation and modifications in chemical properties of an Oxisol, after 59 months of application. The experiment was carried in an experimental field of Embrapa Cerrado, in Planaltina - DF and was established under randomized blocks design with four replicates and two treatments: control $\left(0 \mathrm{Mg} \mathrm{ha}^{-1}\right)$ and recommended dose $(5 \mathrm{Mg}$ $\left.\mathrm{ha}^{-1}\right)$. Gypsum was broadcasted on the soil surface after planting of sugarcane in the winter, in July 2009. Sugarcane yield and quality were evaluated in plant cane and three ratoons crops. Soil sampling was performed after evaluation of the third ratoon in seven layers $(0-5 ; 5-10 ; 10-20 ; 20-40 ; 40-60 ; 60-80$ and $80-100 \mathrm{~cm})$ aiming to determine the following chemical characteristics: $\mathrm{pH}$ in $\mathrm{H}_{2} \mathrm{O}$ and $\mathrm{CaCl}_{2}$; exchangeable aluminum $\left(\mathrm{Al}^{3+}\right)$ exchangeable cations $\left(\mathrm{Ca}^{2+}, \mathrm{Mg}^{2+}\right.$ and $\left.\mathrm{K}^{+}\right)$, potential acidity $(\mathrm{H}+\mathrm{Al})$; sulfur $(\mathrm{S}-$ $\mathrm{SO}_{4}{ }^{2-}$ ) and easily oxidizable organic matter (MO). The use of gypsum increased yield of stalks and total reducing sugars in plant cane and the three ratoons, and resulted in higher $\mathrm{Ca}^{2+}, \mathrm{Mg}^{2+}$ and $\mathrm{SO}_{4}{ }^{2-}$ levels and lower saturation of aluminum in layers of 20$100 \mathrm{~cm}, 40-100 \mathrm{~cm}, 0-100 \mathrm{~cm}$ and 40-100 cm, respectively. Moreover, gypsum resulted in larger amounts of organic matter and higher cation exchange capacity in the layer $40-100 \mathrm{~cm}$.

Keywords: sulfur, dry spells, aluminum saturation, organic matter

\subsection{INTRODUÇÃO}

O Brasil contribui anualmente com aproximadamente $40 \%$ da produção mundial de cana-de-açúcar (FAOSTAT, 2012) e deverá cultivar 9 milhões de hectares na safra 2014/15 (CONAB, 2015). Os principais produtos obtidos são o açúcar e o etanol, que representam grande importância para a economia brasileira. Assim, o Brasil lidera a produção mundial de cana-de-açúcar e o etanol corresponde a $38 \%$ do consumo de combustíveis dos motores Ciclo-Otto no país (MME, 2014). Além disso, a biomassa do 
bagaço da cana-de-açúcar é outro produto de importância estratégica para o país, pois seu aproveitamento nas usinas contribui com $20 \%$ da energia utilizada no setor industrial brasileiro (EPE, 2013).

$\mathrm{Na}$ última década a expansão em área com cana-de-açúcar no Brasil foi de 3,16 milhões de hectare, representando incremento de 54\% (CONAB, 2015). A região de maior contribuição nesse crescimento foi a Centro-Oeste com 1,2 milhões de hectares, o que representou um acréscimo de $220 \%$ em área destinada à essa cultura. Mesmo com as adversidades climáticas ocorrentes na Região Centro-Oeste, a estimativa (2014/15) de rendimento de colmos é 73,7 $\mathrm{Mg} \mathrm{ha}^{-1}$ (CONAB, 2015).

Apesar do cenário positivo para a produção de cana-de-açúcar no Brasil, ainda existem fatores que limitam o alcance de maiores produtividades. A produtividade média brasileira prevista para safra 2014/15 está em torno de 71,3 $\mathrm{Mg} \mathrm{ha}^{-1}$, no entanto, o potencial produtivo pode alcançar valores superiores $200 \mathrm{Mg} \mathrm{ha}^{-1}$ (Waclawovsky et al., 2010). Dentre os principais limitantes da produtividade na cana-de-açúcar está a deficiência hídrica (Machado et al., 2009; Basnayake et al., 2012), que atinge predominantemente as regiões de expansão do cultivo da cultura.

A estacionalidade climática característica das regiões que abrangem o bioma Cerrado, concentrando o período chuvoso entre os meses de outubro a abril e a ocorrência dos "veranicos" são os principais fatores que contribuem para as perdas em produtividade por deficiência hídrica. Os "veranicos" são interrupções pluviométricas durante a estação chuvosa que geralmente duram de uma a três semanas, associadas com altas taxas de evapotranspiração (Cochrane et al., 1988; Lopes et al., 2012).

Os impactos causados pela ocorrência de veranicos já são bem conhecidos e podem ser intensificados, devido ao predomínio de teores de cálcio menores que 0,4 $\mathrm{cmol}_{\mathrm{c}} \mathrm{dm}^{-3}$ e saturação por alumínio superior à $10 \%$ na camada de $21-50 \mathrm{~cm}$ dos solos do Cerrado (Cochrane \& Azevedo, 1988). Nessas condições, ocorre restrição ao crescimento radicular em profundidade do solo (abaixo de $20 \mathrm{~cm}$ ) e, consequentemente, menor utilização da água e nutrientes disponíveis no perfil do solo durante os veranicos (Sousa et al., 2005).

Em trabalho clássico conduzido por Ritchey et al. (1981) no Cerrado em Latossolo argiloso em condições controladas, em diferentes camadas com colunas de 1,2 $\mathrm{m}$, demostraram a eficiência do sulfato de cálcio $\left(\mathrm{CaSO}_{4}\right)$ em promover a movimentação do cálcio até $75 \mathrm{~cm}$ em colunas de solo, após a percolação de $1200 \mathrm{~mm}$ 
de água. Foi observada também a redução na saturação por alumínio em profundidade do solo.

$\mathrm{O}$ gesso agrícola ou mineral $\left(\mathrm{CaSO}_{4} \cdot 2 \mathrm{H}_{2} \mathrm{O}\right)$ vem sendo amplamente utilizado com a finalidade de fornecer nutrientes e corrigir a toxidez por alumínio em profundidade no solo (Sousa \& Rein, 2009; Serafim et al., 2012; Lee \& Mudge, 2013; Rampim et al., 2013), após a correção do pH da camada superficial com aplicação de calcário. Assim, o gesso pode proporcionar teores de cálcio e magnésio $\left(\mathrm{Ca}^{2+}+\mathrm{Mg}^{2+}\right)$ acima de $1 \mathrm{cmol}_{\mathrm{c}} \mathrm{dm}^{-3}$ e de sulfato superiores à $0,4 \mathrm{~cm} \mathrm{cmol}_{\mathrm{c}} \mathrm{dm}^{-3}$, em profundidade, após período de 39 meses da sua aplicação em Latossolo Argiloso (Sousa et al., 2005).

Dessa forma, o gesso é considerado um condicionador de subsuperfície para o desenvolvimento radicular, pois favorece a melhor distribuição e o crescimento das raízes, a partir da correção dos teores de cálcio e da toxidez de alumínio no perfil do solo (Caires et al., 2001; Santos et al., 2013; Pauletti et al., 2014). Esses benefícios podem reduzir os efeitos adversos dos veranicos e, consequentemente, as perdas em produtividade resultantes da sua ocorrência, conferindo maior estabilidade na produção agrícola brasileira, em especial na região do Cerrado.

A cana-de-açúcar é uma cultura semi-perene que necessita de alta disponibilidade hídrica, entre 1100 a 1300 mm na Região Centro-Oeste, bem distribuída durante todo o ciclo, em média de doze meses (Hernandes et al., 2014). Essa característica associada à sua expansão para o Cerrado com adversidades climáticas e químicas do solo necessita de tecnologias que minimizem os riscos das perdas em produtividade.

O uso de gesso pode ser uma solução viável para redução dessas potenciais perdas em produtividade, requerendo maior compreensão dessa tecnologia. Portanto, o objetivo desse trabalho foi avaliar a influência da aplicação de gesso na produtividade e qualidade tecnológica da cultura de cana-de-açúcar e também nos atributos químicos de um Latossolo Vermelho no Cerrado.

\subsection{MATERIAL E MÉTODOS}

\subsubsection{Descrição e manejo da Área Experimental}

O experimento foi conduzido numa área experimental localizada na Embrapa Cerrados, em Planaltina - DF (latitude $15^{\circ} 36^{\prime} \mathrm{S}$, longitude de $47^{\circ} 42^{\prime} \mathrm{W}$ e altitude de 1014 m). O clima é do tipo Cwa segundo a classificação de Köppen, precipitação média 
anual de $1.570 \mathrm{~mm}$ e temperatura média anual de $21,3{ }^{\circ} \mathrm{C}$. O relevo caracteriza-se como plano, a vegetação original era Cerrado sentido restrito e o solo foi classificado como Latossolo Vermelho distrófico muito argiloso (66\% de argila). A composição mineralógica da fração argila do horizonte diagnóstico do solo estudado consistiu de: caulinita (634 $\left.\mathrm{g} \mathrm{kg}^{-1}\right)$; gibbsita $\left(195 \mathrm{~g} \mathrm{~kg}^{-1}\right)$; hematita $\left(108 \mathrm{~g} \mathrm{~kg}^{-1}\right)$; e goethita $\left(61 \mathrm{~g} \mathrm{~kg}^{-1}\right)$, conforme descrito por Rein (2008).

No início da estação chuvosa de 2009 a área foi dividida em quatro parcelas e amostrada nas profundidades de 0-20, 20-40 e 40-60 cm. Esta área havia sido desmatada há aproximadamente 35 anos, mas não cultivada anteriormente, mantida sob vegetação de gramíneas (Brachiaria decumbens e Andropogon gayanus).

Na Tabela 5.1 são apresentados os resultados da análise química do solo antes da instalação do experimento. Esses resultados indicaram alta probabilidade de resposta ao gesso como fornecedor de nutrientes e melhorador do ambiente radicular, pois essa área apresentava teores de cálcio muito baixos nas profundidades de 20 a $40 \mathrm{~cm}$ e de 40 a 60 cm, bem como alta saturação por alumínio e baixos teores de enxofre na forma de sulfato em todas as camadas.

Tabela 5.1: Características químicas do solo da área experimental antes da correção e da adubação da área ${ }^{1}$.

\begin{tabular}{cccccccccc}
\hline Camada & $\mathrm{pH}$ & $\mathrm{Ca}$ & $\mathrm{Mg}$ & $\mathrm{K}$ & $\mathrm{CTC}$ & $\mathrm{m}^{2}$ & $\mathrm{~V}$ & ${\mathrm{~S}-\mathrm{SO}_{4}{ }^{2-}}^{\mathrm{P}}$ & $\mathrm{P}$ \\
\hline $\mathrm{cm}$ & & $----------\mathrm{cmol}_{\mathrm{c}} \mathrm{dm}^{-3}---------$ & $-----\%-----$ & $\mathrm{mg} \mathrm{kg}^{-1}$ & $\mathrm{mg} \mathrm{dm}^{-3}$ \\
0 a 20 & $4,9^{2}$ & 0,19 & 0,06 & 0,09 & 8,60 & 77 & 4 & 4,4 & 0,8 \\
20 a 40 & 5,0 & 0,27 & 0,02 & 0,05 & 6,94 & 73 & 5 & 3,4 & 0,6 \\
40 a 60 & 5,0 & 0,16 & 0,01 & 0,03 & 5,50 & 75 & 4 & 2,8 & 0,5 \\
\hline
\end{tabular}

${ }^{1}$ Segundo os métodos descritos em Embrapa (1997), valores médios, $n=4$.

${ }^{2}$ saturação de alumínio.

Em fevereiro de 2009 as doses de corretivos e fertilizantes foram definidas conforme Sousa e Lobato (2004). O calcário dolomítico foi aplicado manualmente na dose de 7,08 $\mathrm{Mg} \mathrm{ha}^{-1}$ (PRNT de 100\%), requerida para elevar a 50\% a saturação por bases do solo na camada de 0-40 cm. O calcário (PRNT 77\%, CaO 36\% e MgO 17\%) foi incorporado inicialmente com grade aradora na profundidade de aproximadamente $20 \mathrm{~cm}$, seguida de aração com arado de aivecas na profundidade de aproximadamente $40 \mathrm{~cm}$ (Figura 5.1a e 5.1b). 

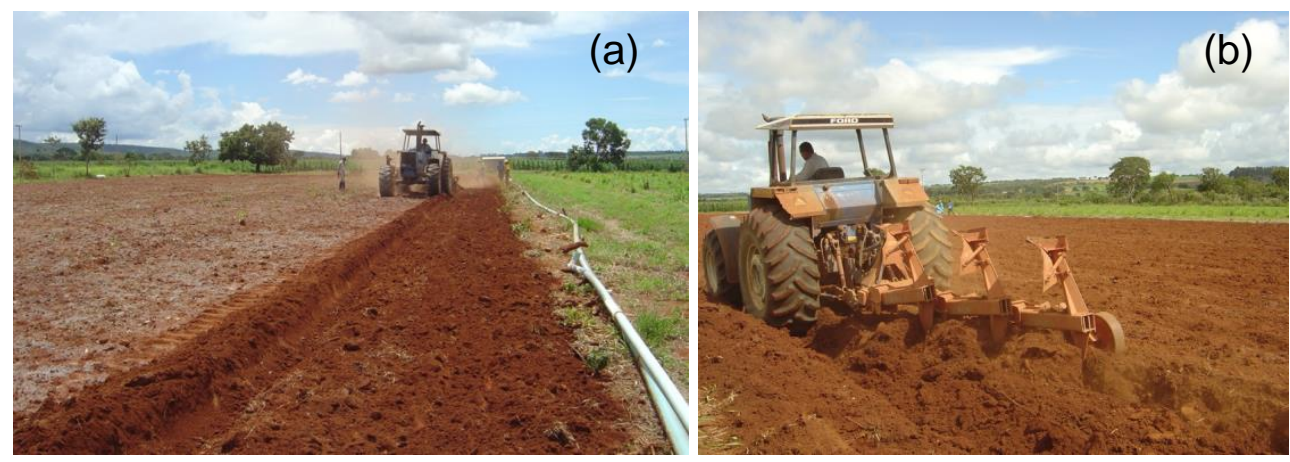

Figura 5.1: Incorporação do calcário com grade aradora na camada de 0-20 cm do solo (a) e aração com arado aivecas na camada de 0-40 cm (b).

Em seguida, $240 \mathrm{~kg} \mathrm{ha}{ }^{-1}$ de $\mathrm{P}_{2} \mathrm{O}_{5}$ foram aplicados, a lanço, na forma de termofosfato magnesiano fundido em pó. Além disso, foram aplicados $120 \mathrm{~kg} \mathrm{ha}^{-1} \mathrm{de}$ $\mathrm{K}_{2} \mathrm{O}$, como cloreto de potássio, e $100 \mathrm{~kg} \mathrm{ha}^{-1}$ de FTE BR 10 em pó, como fonte de micronutrientes, como adubação corretiva, sendo então incorporados ao solo com grade aradora na profundidade $20 \mathrm{~cm}$.

Em março de 2009 a área do experimento foi semeada com Crotalaria juncea (20 sementes por metro, espaçamento de $45 \mathrm{~cm}$ ), prática largamente adotada na região Centro-Sul por ocasião da renovação de canaviais. O adubo verde foi cortado com o equipamento Triton na fase de florescimento.

A cana-de-açúcar foi plantada na estação seca, em julho de 2009. Esta data é referida na região como "plantio de inverno", necessitando de irrigação prévia para umedecer o solo na profundidade de aproximadamente $40 \mathrm{~cm}$, propiciando a sulcação, seguida de irrigações após o plantio da cana para possibilitar a brotação dos rebolos. A área foi então sulcada na profundidade de aproximadamente $40 \mathrm{~cm}$, adubada no sulco com ureia $\left(42 \mathrm{~kg} \mathrm{ha}^{-1}\right.$ de $\left.\mathrm{N}\right)$ e superfosfato triplo $\left(183 \mathrm{~kg} \mathrm{ha}^{-1}\right.$ de $\mathrm{P}_{2} \mathrm{O}_{5}$ ) cobrindo-se o adubo com aproximadamente $7 \mathrm{~cm}$ de solo.

A variedade de cana plantada foi a RB86-7515, de maturação média/tardia (características agronômicas - Anexo 2). As mudas utilizadas de cana planta, com idade de nove meses, foram provenientes de multiplicação efetuada na área experimental da Embrapa Cerrados. Assim, foram plantados três colmos paralelos no sistema "pé com ponta", para garantir a brotação de pelo menos 12 gemas por metro linear, e picados no sulco com "podão" em toletes de aproximadamente três gemas. 
Efetuaram-se quatro irrigações por aspersão de $25 \mathrm{~mm}$ (aspersores convencionais espaçados de $12 \mathrm{~m}$ ) em 4, 14 e 17 de agosto e 17 de setembro de 2009 (Figura 5.2), para garantir a brotação das gemas, dissolução e distribuição do gesso no perfil do solo aplicado a lanço superficialmente após o plantio.

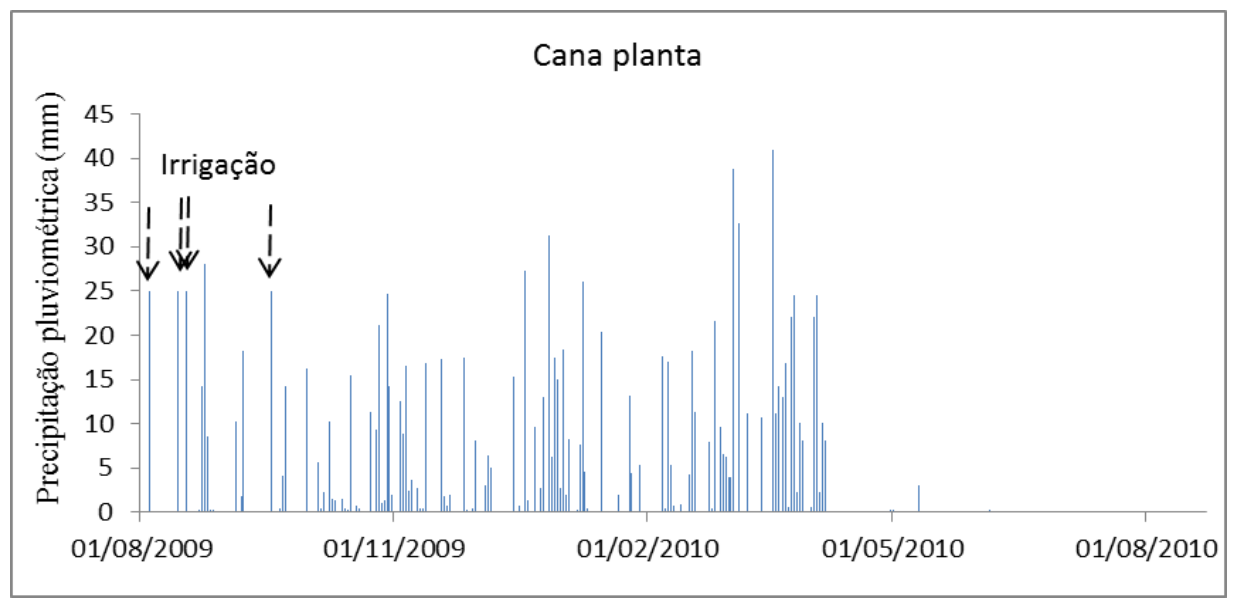

Figura 5.2: Precipitação pluviométrica durante o ciclo de cana planta.

As setas indicam as quatro irrigações para proporcionar brotação dos rebolos, nos dias 4/08/2009, 14/08/2009, 17/08/2009 e 17/09/2009 compostas de $25 \mathrm{~mm}$ para cada dia.

Durante a condução do experimento, as plantas daninhas foram manejadas com herbicidas pré-emergentes para cana-de-açúcar, e herbicidas pós-emergentes em jato dirigido, complementados com capinas manuais. Em 26 de novembro de 2009 foi realizada a adubação de cobertura com $60 \mathrm{~kg} \mathrm{ha}^{-1}$ de $\mathrm{N}$ na forma de ureia e $150 \mathrm{~kg} \mathrm{ha}^{-1}$ de $\mathrm{K}_{2} \mathrm{O}$ na forma de cloreto de potássio. Essas doses de $\mathrm{N}$ e $\mathrm{K}_{2} \mathrm{O}$ correspondem às doses de plantio recomendadas para a cultura no Cerrado (Sousa \& Lobato, 2004).

$\mathrm{Na}$ estação seca foi efetuada a colheita da cana planta entre os dias 18 e 22 de agosto de 2010, dessa forma para propiciar o pleno rebrote da soqueira realizou-se irrigação suplementar, através de sistema de aspersão convencional (aspersores espaçados de $12 \mathrm{~m}$ ), aplicando-se duas lâminas de 57,4 mm cada, sendo a primeira alguns dias após o corte (31 de agosto de 2010), e a segunda duas semanas após a primeira, em 14 de setembro de 2010 (Figura 5.3). Adubação de manutenção da primeira soca com nitrogênio e potássio foi efetuada em 17 de novembro de 2010 (120 $\mathrm{kg} \mathrm{ha}^{-1}$ de $\mathrm{N}$ na forma de nitrato de amônio e $150 \mathrm{~kg} \mathrm{ha}^{-1}$ de $\mathrm{K}_{2} \mathrm{O}$ na forma de cloreto de potássio), no início da estação chuvosa. 
O corte da primeira soca ocorreu no período de 16 a 23 de agosto de 2011, após a colheita foi passado na área o triton, para picar a palha da cana. Em setembro efetuouse $150 \mathrm{~mm}$ de irrigação, composta de três irrigações de $50 \mathrm{~mm}$ a cada quinze dias (Figura 5.3). A adubação de manutenção da segunda soca com nitrogênio, fósforo e potássio ocorreram no dia primeiro de novembro de 2011 (120 kg ha ${ }^{-1}$ de nitrogênio, 50 $\mathrm{kg} \mathrm{ha}^{-1}$ de $\mathrm{P}_{2} \mathrm{O}_{5}, 150 \mathrm{~kg} \mathrm{ha}^{-1}$ de $\mathrm{K}_{2} \mathrm{O}$, com as seguintes fontes: nitrato de amônio, fosfato monoamônico e cloreto de potássio).

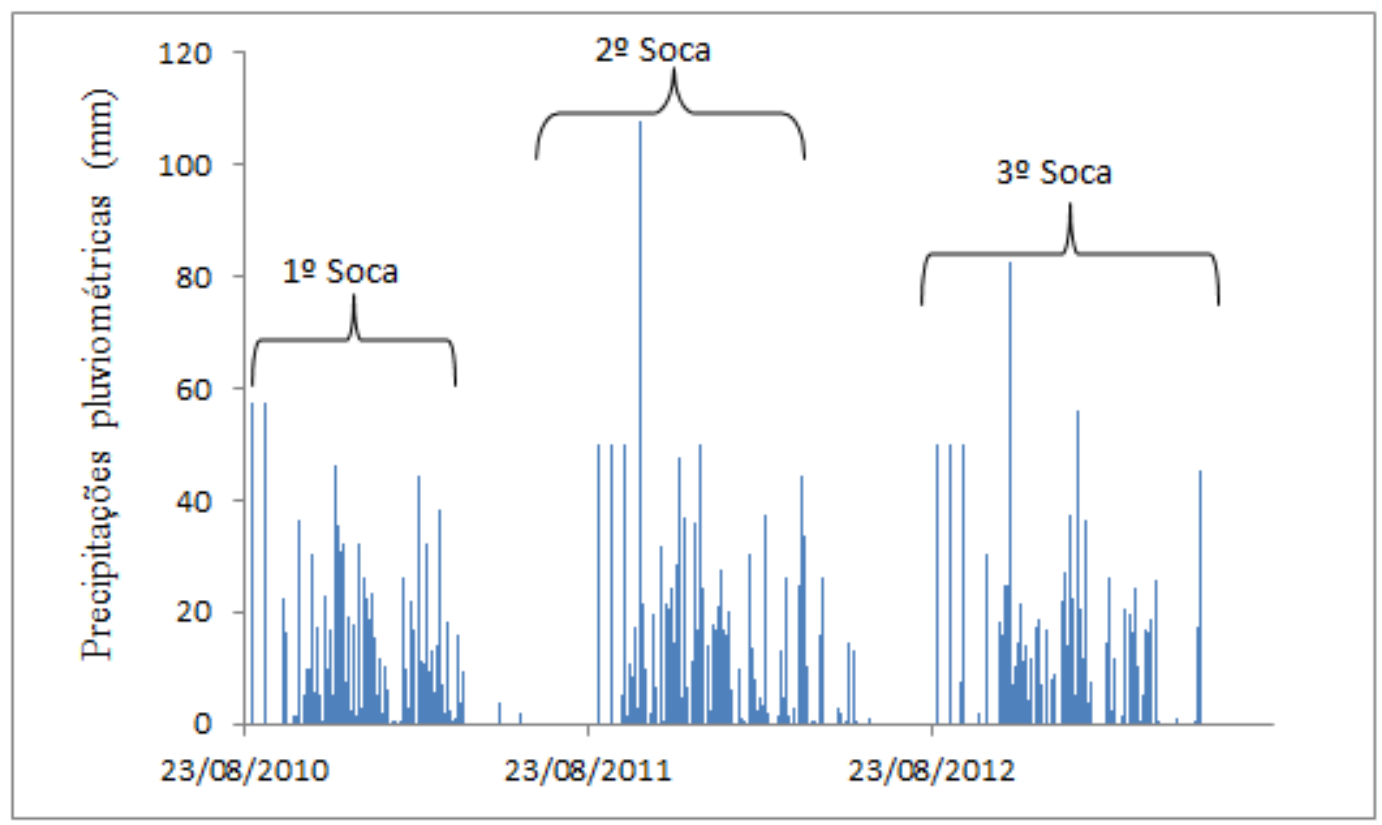

Figura 5.3: Precipitações pluviométricas durante o ciclo das três canas socas e irrigações suplementares. $\mathrm{Na} 1^{\circ}$ soca as irrigações foram compostas de duas aplicações de 57,4 mm (31/08 e 14/09/2010), totalizando $114,8 \mathrm{~mm}$. Na $2^{\circ}$ soca nos dias 01/09 e 15/09 e 29/09/2011 e na $3^{\circ}$ soca nos dias 27/08, 10/09 e 24/09/2012, aplicou-se para cada ciclo $150 \mathrm{~mm}$, divididos em três irrigações de 50 $\mathrm{mm}$.

A segunda soca foi colhida no período de 12 a 17 de agosto de 2012, passandose o triton após o corte. Dez dias após o corte (27 de agosto de 2012) iniciou-se a irrigação suplementar, composta de três irrigações de $50 \mathrm{~mm}$ a cada quinze dias (Figura 5.3). Na adubação de manutenção da $3^{\mathrm{a}}$ soca utilizaram-se as mesmas quantidades e fontes de nitrogênio, fósforo e potássio aplicadas na segunda soca $\left(120 \mathrm{~kg} \mathrm{ha}^{-1} \mathrm{de}\right.$ nitrogênio, $50 \mathrm{~kg} \mathrm{ha}^{-1}$ de $\mathrm{P}_{2} \mathrm{O}_{5}, 150 \mathrm{~kg} \mathrm{ha}^{-1}$ de $\mathrm{K}_{2} \mathrm{O}$ ). A colheita da terceira soca ocorreu de 10 a 20 de agosto de 2013. Os tratos culturais após a colheita seguiram a mesma 
metodologia utilizada para primeira e segunda socas, com utilização do triton e irrigação suplementar (Figura 5.3). As temperaturas máximas, mínimas e médias registradas durante os ciclos da cana-planta e as três socas são apresentadas no Anexo 1.

\subsubsection{Delineamento experimental e definição dos tratamentos}

$\mathrm{O}$ tratamento com gesso agrícola $\left(\mathrm{CaSO}_{4} \cdot 2 \mathrm{H}_{2} \mathrm{O}\right)$ foi aplicado em 29 de julho de 2009 a lanço na superfície do solo após o plantio da cana-de-açúcar. A dose do gesso foi calculada conforme a expressão $[\mathrm{Y}=75 \mathrm{X}]$, em que $\mathrm{Y}$ é a dose de gesso (base $15 \%$ de enxofre) expressa em $\mathrm{kg} \mathrm{ha}^{-1}$, e X é o teor de argila (\%) na camada de 40-60 $\mathrm{cm}$ conforme prescrito por Sousa e Lobato (2004).

O experimento é composto por cinco tratamentos, representados pelas doses crescentes de gesso: $0 ; 0,5 ; 2,5 ; 5,0$ e $10 \mathrm{Mg} \mathrm{ha}^{-1}$. No entanto, para a realização desse trabalho, foram utilizados apenas dois tratamentos: a testemunha com $0 \mathrm{Mg} \mathrm{ha}^{-1} \mathrm{e}$ a dose de $5 \mathrm{Mg} \mathrm{ha}^{-1}$, recomendada para o solo estudado, que apresenta $66 \%$ de argila. $\mathrm{O}$ delineamento experimental é de blocos casualizados, com 4 repetições. As parcelas experimentais consistem de 5 linhas de $8 \mathrm{~m}$ de comprimento $\left(60 \mathrm{~m}^{2}\right)$, espaçadas em 1,5 $\mathrm{m}$, que corresponde ao espaçamento adotado no Brasil para a colheita mecanizada da cana-de-açúcar.

\subsubsection{Amostragem do solo}

As amostras de solo foram coletadas em setembro de 2013, um mês após a colheita da terceira soca. Nas profundidades de 0-5 e 5-10 cm utilizou-se anel volumétrico de $100 \mathrm{~cm}^{-3}$ e 5 cm de diâmetro, nas demais camadas, 10-20; 20-40; 40-60; 60-80 e 80-100 cm, foi utilizado o trado holandês. A coleta com anel volumétrico nas profundidades superficiais foi utilizada para evitar a contaminação das amostras nas demais profundidades, pois na camada de $0-10 \mathrm{~cm}$ é onde ocorrem os maiores teores de nutrientes. Uma amostra composta foi obtida em cada parcela do experimento. Para cada amostra composta foram coletadas 6 sub-amostras, uma na linha e cinco na entrelinha, equidistantes.

A coleta das sub-amostras foi realizada buscando-se representar a heterogeneidade do sistema na linha e na entre linha de plantio, conforme ilustrado na Figura 5.4 ("a" e "b"). Para a realização das análises químicas do solo, as amostras foram homogeneizadas, secas ao ar e passadas em peneira de malha $2 \mathrm{~mm}$. 

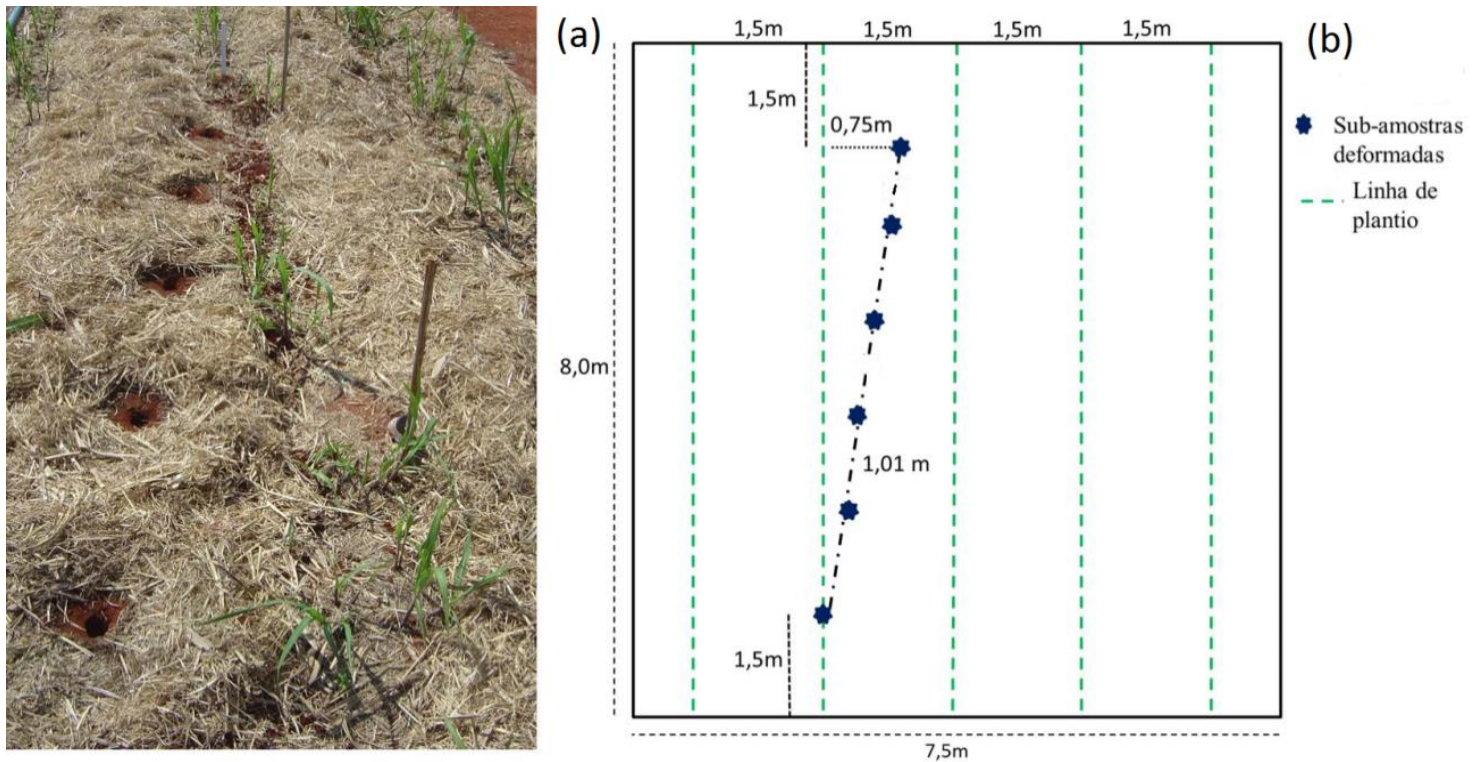

Figura 5.4: Ilustração de coleta das sub-amostras na parcela experimental. Imagem dos seis pontos de coleta das sub-amostras para a composição de uma amostra composta deformada (a) e representação esquemática dos seis pontos de coleta das amostras deformadas (b).

\subsubsection{Determinação da produtividade de colmos e qualidade tecnológica}

Os cortes da cana planta e socas foram realizados manualmente, sem despalha a fogo (cana crua). A área útil colhida consistiu das 3 linhas centrais da parcela de $5 \mathrm{~m}$ de comprimento, após exclusão de 1,5 m em cada extremidade da parcela, totalizando 22,5 $\mathrm{m}^{2}$. Foram avaliadas a produtividade total de colmos por hectare $(\mathrm{TCH})$ e de açúcares redutores totais (ART), conforme os protocolos do CONSECANA (2006). Para isso, foram tomadas amostras de 10 colmos por parcela, picados em conjunto desintegradorhomogeneizador, tomando-se em seguida amostra de $500 \mathrm{~g}$ do material triturado, que foi submetida a prensagem para extração do caldo.

O procedimento foi efetuado em prensa hidráulica, com a amostra em recipiente cilíndrico de aço inoxidável, submetida à pressão de $250 \mathrm{kgf} \mathrm{cm}^{-2}$ durante 1 minuto. No caldo foi analisado o brix (sólidos solúveis) em refratômetro de bancada com correção automática de temperatura. Clarificante (“octapol”) foi adicionado ao caldo, que foi em seguida filtrado, efetuando-se a leitura sacarimétrica (POL) em sacarímetro provido de tubo polarimétrico de fluxo contínuo. Rendimentos por hectare de açúcares redutores totais (ART) foram quantificados de acordo com CONSECANA (2006). 


\subsubsection{Analises químicas do solo}

As análises químicas foram realizadas nos laboratórios da Embrapa Cerrados. O pH em água e em cloreto de cálcio $\left(\mathrm{CaCl}_{2}\right)$ foram determinados em peagâmetro de bancada. Para os teores de Potássio $\left(\mathrm{K}^{+}\right)$foi usado o extrator Mehlich-1 e a leitura foi realizada por espectrofotometria de chama.

$\mathrm{Na}$ determinação da acidez potencial $(\mathrm{H}+\mathrm{Al})$ foi utilizado como extrator uma solução de acetato de cálcio $0,5 \mathrm{~mol} \mathrm{~L}^{-1}$ a pH 7 quantificado por titulação com solução de hidróxido de sódio $0,02 \mathrm{~mol} \mathrm{~L}^{-1}$. Para o cálcio $\left(\mathrm{Ca}^{2+}\right)$, magnésio $\left(\mathrm{Mg}^{2+}\right)$ e alumínio trocáveis $\left(\mathrm{Al}^{3+}\right)$ foram extraídos com cloreto de potássio $0,5 \mathrm{~mol} \mathrm{~L}^{-1}$, sendo o $\mathrm{Ca}^{2+}$ e o $\mathrm{Mg}^{2+}$ quantificados por Espectrômetro de absorção atômica e o $\mathrm{Al}^{3+}$ quantificado por titulação com solução de hidróxido de sódio $0,01 \mathrm{~mol} \mathrm{~L}^{-1}$. O enxofre $\left(\mathrm{SO}_{4}{ }^{2-}\right)$ foi extraído com fosfato de cálcio monobásico monohidratado $0,01 \mathrm{~mol} \mathrm{~L}^{-1}$, na relação solo:solução, 1:5 e quantificado por Espectroscopia de Emissão Atômica com Plasma de Argônio Indutivamente Acoplado (ICP-OES). A matéria orgânica facilmente oxidável foi determinada por oxidação com dicromato de potássio, sem fonte externa de calor, em 1,0 g de solo, conforme Walkley \& Black (1934).

A capacidade de troca de cátions (CTC) à $\mathrm{pH}=7$ foi calculada pela seguinte fórmula: CTC $\left(\mathrm{cmol}_{\mathrm{c}} \mathrm{dm}^{-3}\right)=\mathrm{S}+\mathrm{H}+\mathrm{Al}$, sendo a soma de bases $(\mathrm{S}) \mathrm{em} \mathrm{cmol}_{\mathrm{c}} \mathrm{dm}^{-3}=$ $\mathrm{Ca}^{2+}+\mathrm{Mg}^{2+}+\mathrm{K}^{+}$. A CTC efetiva $\left(\mathrm{CTC}_{\mathrm{ef}}\right)$ foi calculada da seguinte forma: $\mathrm{CTC}_{\mathrm{ef}}=$ $\mathrm{S}+\mathrm{Al}^{3+}$, enquanto que a saturação de bases na $\mathrm{CTC}_{\mathrm{ef}}$ foi obtida pela relação da $\mathrm{S} / \mathrm{CTC}_{\mathrm{ef}}$ e a saturação de $\mathrm{Ca}^{2+}$ pela relação $\mathrm{Ca}^{2+} / \mathrm{CTC}_{\text {ef. }}$. Todas as análises químicas foram determinadas segundo Embrapa (1997).

\subsubsection{Análise Estatística}

Para a análise de variância de produtividade de colmos e de açúcares redutores totais foi utilizado o seguinte modelo:

$$
\mathrm{Y}_{\mathrm{ij}}=\mu+\mathrm{B}_{\mathrm{i}}+\mathrm{T}_{\mathrm{j}}+\operatorname{erro}(\mathrm{ij})
$$

Para a análise de variância dos atributos químicos nas camadas de solo foi utilizado o seguinte modelo:

$$
\mathrm{Y}_{\mathrm{ijm}}=\mu+\mathrm{B}_{\mathrm{i}}+\mathrm{T}_{\mathrm{j}}+\text { erro (ij) }+\mathrm{C}_{\mathrm{m}}+\mathrm{TC}_{\mathrm{jm}}+\text { erro (ijm) }
$$

Onde $\mu=$ média geral dos dados; $\mathrm{B}=$ bloco $(\mathrm{i}=1,2,3,4) ; \mathrm{T}=$ tratamento $(\mathrm{j}=$ $1,2) ; \mathrm{C}=$ camada $(\mathrm{m}=1,2,3,4,5)$, foi considerado a média ponderada das camadas de 0 5, 5-10 e 10-20 cm representada pela camada de 0-20 cm; erro = erro experimental. 
Análise de variância foi realizada com o PROC MIXED do software SAS 9.1 (Statistical Analysis System) e quando esta apresentou significância o teste t $(p<0,05)$ foi utilizado para distinção das médias.

Para a relação entre os teores de matéria orgânica facilmente oxidável e a capacidade de troca catiônica (CTC $\mathrm{pH}$ 7) foi gerada uma equação de regressão linear utilizando o software SigmaPlot 10.

\subsection{RESULTADOS E DISCUSSÃO}

\subsubsection{Produtividade de colmos e qualidade tecnológica}

O uso do gesso promoveu maior produtividade total de colmos por hectare $(\mathrm{TCH})$ e de açúcares redutores totais (ART) na cana-de-açúcar. Esse aumento de produtividade promovido pelo gesso ocorreu nos quatro ciclos de cultivo da cana, cujos valores de THC variaram de 69 a $143 \mathrm{Mg} \mathrm{ha}^{-1}$ (Figura 5.5a) e de ART de 13 a $25 \mathrm{Mg}$ ha $^{-}$ ${ }^{1}$ (Figura 5.5b). A cana planta no tratamento sob aplicação de gesso produziu 74,4; 41,5 e 23,3\% de TCH a mais que a primeira, segunda e a terceira soca, respectivamente.

A maior produtividade da cana-planta está associada ao crescimento vigoroso e a alta ramificação do sistema radicular, quando comparado com a cana-soca (Ball-Coelho et al., 1992; Battie Laclau \& Laclau, 2009) e também ao maior ciclo da cana-planta, (Otto, 2012).

A cana de primeira soca sob uso de gesso apresentou redução de $23,7 \%$ e $41,5 \%$ na produtividade em relação às duas socas sucessivas, respectivamente, devido ao menor volume e a distribuição das precipitações ocorridas nesse período (2010/11), que foi de $1304 \mathrm{~mm}$, concentrando $738 \mathrm{~mm}$ no primeiro trimestre, após o rebrote. A partir da segunda-soca maiores volumes de precipitações, de 1662 e 1379 mm para os períodos de 2011/12 e 2012/13, respectivamente (Figura 5.3), proporcionaram a recuperação das produtividades na segunda e terceira socas (Figura 5.5).

A lâmina de água acumulada durante os anos de cultivo da cana proporcionou a movimentação do sulfato acompanhado por cátions no perfil do solo, que podem ter favorecido o desenvolvimento radicular em profundidade, com maior eficiência na utilização da água disponível no perfil do solo, e consequentemente incrementos em produtividade para as socas (Sousa \& Ritchey, 1985). Isso pode explicar, em parte, a 
produtividade da terceira soca ser superior à primeira soca com volume de precipitação semelhantes.

Os incrementos em TCH com o uso do gesso foram crescentes da cana-planta para as três socas avaliadas, em relação à não aplicação de gesso, com valores observados de 10,0,18,8,20,2 e 20,8\% para cana-planta, primeira, segunda e terceira soca, respectivamente.

Os crescentes ganhos em produtividade observados a partir da cana-planta pelo uso do gesso estão também associados ao fornecimento de enxofre $\left(\mathrm{S}_{-} \mathrm{SO}_{4}{ }^{-2}\right)$, que está entre os cinco nutrientes de maior exigência pela cana-de-açúcar. Em média, é exportado 0,36 $\mathrm{kg}$ de $\mathrm{S}$ para a produção de uma tonelada de colmos (Malavolta et al., 1997; Oliveira, 2011) e cultivos contínuos ocasionam maior exportação desse nutriente, ampliando a magnitude de resposta das soqueiras, em relação a não aplicação de $\mathrm{S}$ no tratamento sem gesso. Outro fator que favorece a tendência de crescentes incrementos em produtividade é o aumento nos teores de cálcio nas camadas profundas devido à movimentação do $\mathrm{S}_{-} \mathrm{SO}_{4}{ }^{-2}$ em profundidade ocasionada pela lixiviação durante o cultivo da cana-de-açúcar.
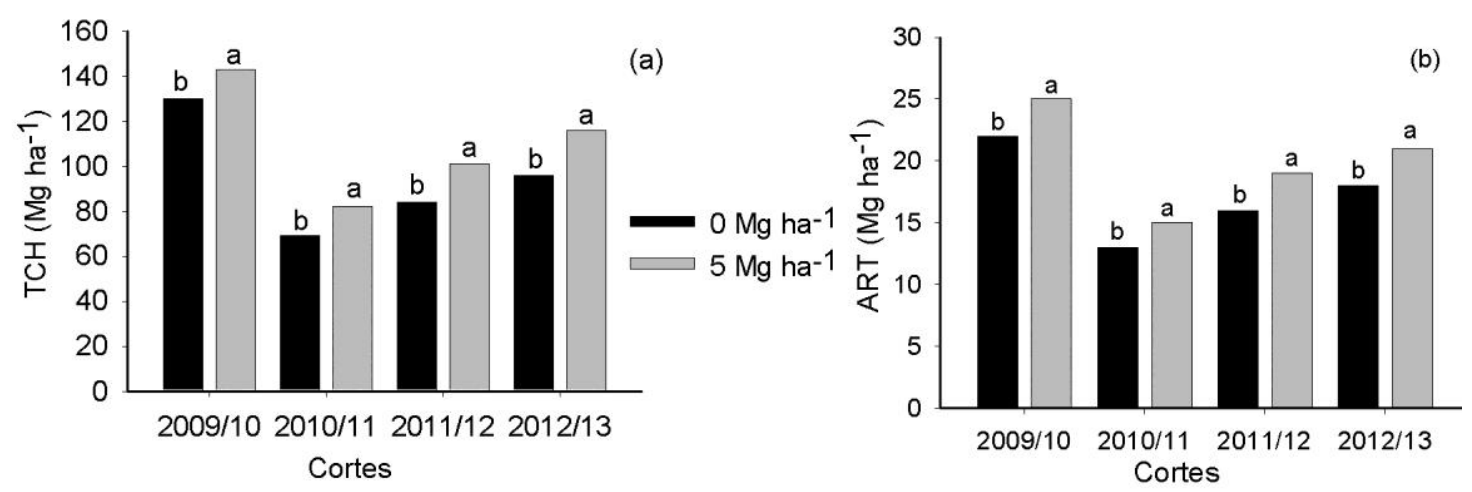

Figura 5.5: Produtividade de colmos por hectare $(\mathrm{TCH})$ (a) e de açúcares redutores totais (ART) (b) de cana-de-açúcar nos ciclos de cana planta (2009-10), primeira soca (2010-11), segunda soca (2011-12) e terceira soca (2012-13) em resposta a doses de gesso aplicado no plantio da cana, em Latossolo muito argiloso. *Significativo pelo teste $t(\mathrm{p}<0,05)$.

Ganhos em produtividade da cana-de-açúcar devido ao uso do gesso têm sido relatados em diversos trabalhos (Morelli et al., 1987; Demattê et al., 2011; Lima et al., 2013), especialmente devido ao fornecimento de cálcio $\left(\mathrm{Ca}^{2+}\right)$ no perfil do solo. Além 
disso, promove a redução na saturação por alumínio $\left(\mathrm{Al}^{3+}\right)$, favorecendo o maior crescimento e distribuição do sistema radicular no perfil do solo, e consequentemente a melhor utilização da água e nutrientes disponíveis no solo (Sousa et al., 2005).

\subsubsection{Atributos químicos do solo}

A adição de gesso elevou os valores de $\mathrm{pH} \mathrm{H}_{2} \mathrm{O}$ do solo na camada de 60-100 cm e de 40-100 cm para pH em $\mathrm{CaCl}_{2}$, após 50 meses da aplicação (Figura 5.6a e 5.6b). No entanto, para a camada de 0-40 cm esse efeito não foi observado, provavelmente, devido a incorporação de $7 \mathrm{Mg} \mathrm{ha}^{-1}$ de calcário nos dois tratamentos, dose recomendada para elevar à 50\% a saturação por bases do solo nessa camada (Figura 5.1).

Os valores de $\mathrm{pH}$ em $\mathrm{H}_{2} \mathrm{O}$ variaram de 4,5 a 5,9, enquanto menores valores foram observados para o $\mathrm{pH}$ em $\mathrm{CaCl}_{2}(4,1$ a 5,0$)$ em todas as camadas, independente da aplicação de gesso, confirmando o predomínio de cargas negativas no perfil do solo. A presença de sais solúveis pode interferir na determinação do $\mathrm{pH}$ em $\mathrm{H}_{2} \mathrm{O}$, o que não ocorre para o $\mathrm{pH}$ em $\mathrm{CaCl}_{2}\left(10 \mathrm{mmol} \mathrm{L}{ }^{-1}\right)$ devido aos eletrólitos presentes na solução (Schofield \& Taylor, 1955; Sousa et al., 2007). Essa condição pode ter contribuído para que o aumento do $\mathrm{pH}$ em resposta à aplicação de gesso na camada de 40-60 cm tenha sido detectado apenas para o $\mathrm{pH}$ em $\mathrm{CaCl}_{2}$.

$\mathrm{O}$ aumento do $\mathrm{pH}$ nas camadas mais profundas avaliadas proporcionado pela aplicação de gesso está associado ao deslocamento de hidroxilas $\left(\mathrm{OH}^{-}\right)$das superfícies dos óxidos e hidróxidos de ferro e alumínio por íons de sulfato $\left(\mathrm{SO}_{4}{ }^{-2}\right)$, quando dissociados do cálcio $\left(\mathrm{Ca}^{2+}\right)$, conhecido como auto-calagem (Reeve \& Summer, 1972; Caires et al., 2003; Rampim et al., 2011). Apesar da menor preferência pelos sítios de adsorção das superfícies das argilas por $\mathrm{SO}_{4}^{-2}$ quando comparados com a $\mathrm{OH}^{-}$, o deslocamento é promovido pelo efeito da maior concentração do $\mathrm{SO}_{4}{ }^{-2}$ no perfil do solo após aplicação de gesso.

A aplicação de gesso reduziu os teores de alumínio trocável $\left(\mathrm{Al}^{3+}\right)$ nas camadas de 20-40 e 60-80 cm, não promovendo alteração nas demais camadas (Figura 5.6c). Já para a saturação de alumínio (m), foram verificadas reduções de 12, 29 e $28 \%$ para as camadas de 40-60; 60-80 e 80-100 cm, respectivamente, em resposta à aplicação de gesso (Figura 5.6d).

A redução no $\mathrm{Al}^{3+}$ trocável e, consequentemente, na saturação de alumínio (m) está relacionada com a hidrólise e precipitação do $\mathrm{Al}^{3+}$, ocasionada pelo aumento do $\mathrm{pH}$ 
em resposta ao uso do gesso. Além disso, há formação de pares iônicos $\mathrm{AlSO}_{4}{ }^{+}$na solução do solo, que trata-se de mecanismo importante para a redução da atividade do alumínio (espécie $\mathrm{Al}^{3+}$ ). A formação de íons $\mathrm{AlSO}_{4}{ }^{+}$, que possuem menor valência quando comparados com $\mathrm{Al}^{+3}$, possibilita aumento de sua mobilidade no perfil do solo e a redução da saturação por alumínio (Pavan \& Volkweiss, 1985; Raij, 1992; Nora \& Amado, 2013).
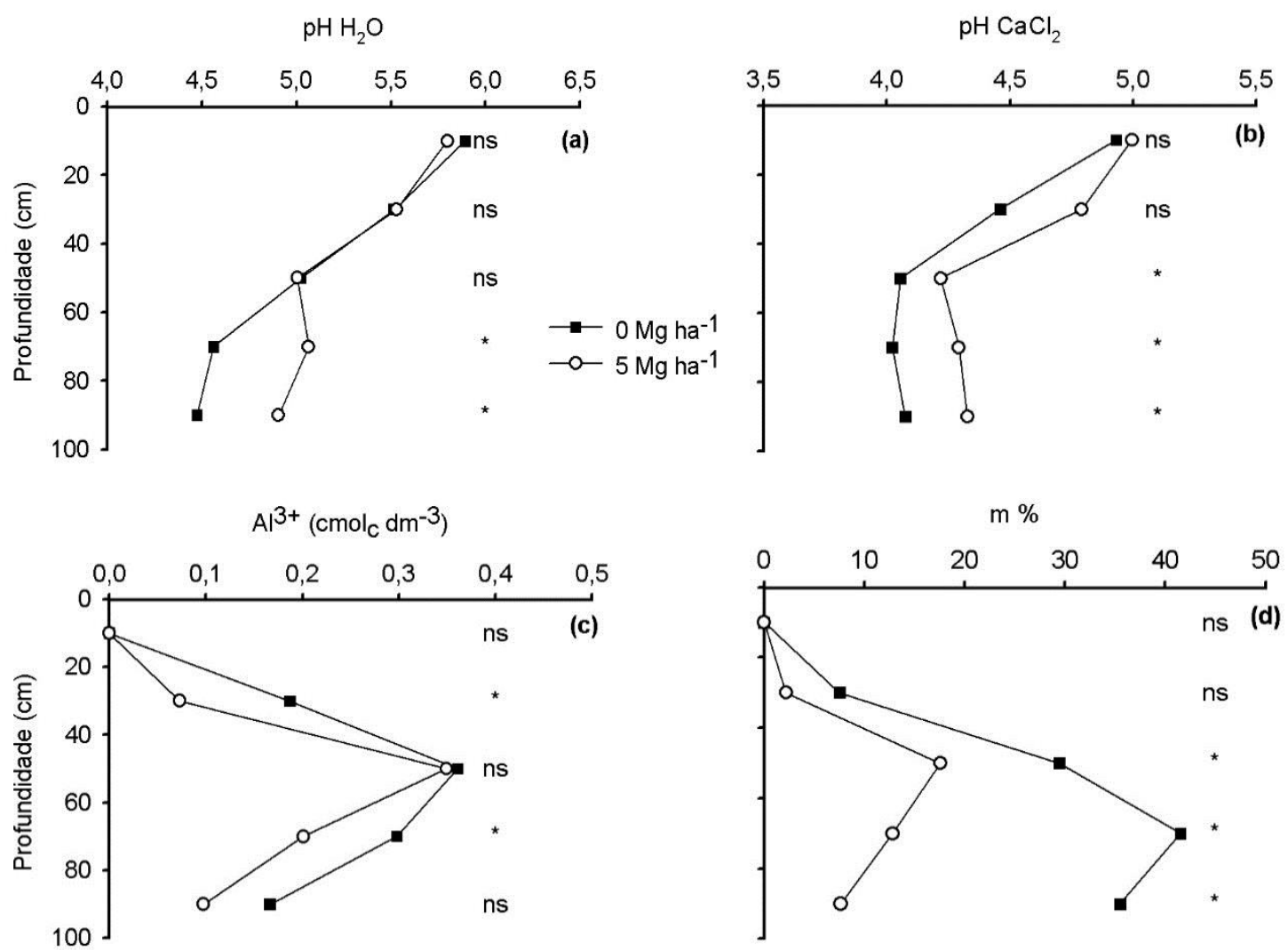

Figura 5.6: $\mathrm{pH}$ em $\mathrm{H}_{2} \mathrm{O}$ (a), $\mathrm{pH}$ em $\mathrm{CaCl}_{2}$ (b), teor de alumínio trocável $\left(\mathrm{Al}^{3+}\right.$ ) (c) e saturação de alumínio (m\%) (d), em cinco profundidades(0-20; 20-40; 40-60; 60-80 e 80-100 cm) de um Latossolo Vermelho, após cultivo de cana-de-açúcar terceira soca em resposta a doses de gesso aplicado no plantio da cana (50 meses após aplicação). *Significativo pelo teste $t(\mathrm{p}<0,05)$.

Em trabalho clássico desenvolvido por Sousa et al. (1992) em 112 amostras de perfis de solo do Cerrado, foi demonstrada a relação inversa entre saturação por alumínio e crescimento radicular de plantas de trigo. Nesse experimento concluiu-se que valores de saturação por alumínio acima de $20 \%$ restringem o crescimento radicular. Assim, no presente estudo, a aplicação de gesso foi eficiente em promover redução desse valor para abaixo de $18 \%$ (figura 5.6d), enquanto que na ausência de gesso na 
camada de 40-100 cm do solo valores elevados de saturação por alumínio podem indicar restrição ao crescimento radicular da cana-de-açúcar.

Os teores de cálcio trocável $\left(\mathrm{Ca}^{2+}\right)$ nas camadas de solo sem aplicação de gesso variaram de 0,1 a $2,4 \mathrm{cmol}_{\mathrm{c}} \mathrm{dm}^{-3}$, enquanto que com o uso de gesso, a variação foi de 0,8 a $3,0 \mathrm{cmol}_{\mathrm{c}} \mathrm{dm}^{-3}$. Dessa forma, para todo o perfil do solo avaliado o gesso elevou os teores de $\mathrm{Ca}^{2+}$, não havendo efeito significativo apenas para a camada superficial do solo $(0-20 \mathrm{~cm})$ (Figura 5.7a).

Em torno de $70 \%$ dos solos do Cerrado apresentam teores de $\mathrm{Ca}^{2+}$ abaixo de 0,4 $\mathrm{cmol}_{\mathrm{c}} \mathrm{dm}^{-3}$, na camada de 21-50 $\mathrm{cm}$ de solo (Cochrane \& Azevedo, 1988) limitando o crescimento do sistema radicular, que necessita de teores acima de $0,5 \mathrm{cmol}_{\mathrm{c}} \mathrm{dm}^{-3}$ para o adequado desenvolvimento (Sousa et al.,1992). O aumento nos teores de $\mathrm{Ca}^{2+}$ trocável no perfil do solo após a aplicação de gesso tem sido reportado em muitos trabalhos (Caires et al., 2006; Santos et al., 2013; Pauletti et al., 2014) devido, principalmente, ao fornecimento de $\mathrm{Ca}^{2+}$ nas camadas de sub-superfície (abaixo de $20 \mathrm{~cm}$ ). Observa-se na figura 5.7a que o uso do gesso favoreceu teores maiores que $0,8 \mathrm{cmol}_{\mathrm{c}} \mathrm{dm}^{-3}$ para todo o perfil de solo avaliado.

Considerando os baixos teores de $\mathrm{Ca}^{2+}$ nos solos do Cerrado e a recente expansão da cana-de-açúcar nesta região, a elevação dos teores desse nutriente proporcionada pelo gesso representa importante estratégia para a sustentabilidade dessa cultura nas condições edafoclimáticas do Cerrado. $\mathrm{O} \mathrm{Ca}^{2+}$ possui importante função no crescimento radicular e na estabilidade da parede celular (Marschner, 2012). Além disso, trabalhos conduzidos por Tuteja \& Mahajan (2007) tem demonstrado importante função desse nutriente no reconhecimento e adaptação às condições de estresse, como temperaturas extremas, deficiência hídrica e salinidade.

O gesso proporcionou aumento nos teores de magnésio trocável $\left(\mathrm{Mg}^{2+}\right)$ nas três últimas camadas de solo avaliadas (40-60, 60-80 e 80-100 cm) (Figura 5.7b). Isso provavelmente está relacionado à reação de troca catiônica favorecida pelo uso do gesso, após a correção da acidez das camadas superficiais, sob atuação do calcário dolomítico. $\mathrm{O}$ fornecimento de $\mathrm{Ca}^{2+}$ através da solubilização do gesso proporciona a substituição do $\mathrm{Mg}^{2+}$ do complexo de troca para a solução do solo, e consequentemente a formação do par iônico $\mathrm{MgSO}_{4}{ }^{0}$, proporcionando o movimento desse nutriente no perfil do solo (Pavan \& Volkweiss, 1985; Serafim et al., 2012).

O teor médio de $\mathrm{Mg}^{2+}$ trocável no perfil de solo $(0-100 \mathrm{~cm})$ sob aplicação de gesso foi de $0,70 \mathrm{cmol}_{\mathrm{c}} \mathrm{dm}^{-3}$, enquanto que na ausência do gesso foi de $0,61 \mathrm{cmol}_{\mathrm{c}} \mathrm{dm}^{-3}$, 
representando um incremento de $15 \%$ no teor de $\mathrm{Mg}^{2+}$ (Figura 5.7b). Tal incremento pode estar relacionado com a alteração da solubilidade do calcário dolomítico pelo uso do gesso, pois quando o solo é saturado com $\mathrm{Ca}^{2+}$ devido à dissolução do gesso, pode ocorrer maior solubilização do carbonato de magnésio em relação ao carbonato de cálcio, aumentando o teor de magnésio no solo, devido ao efeito do íon comum (Mahan \& Myers, 1995). Esse efeito apesar de efêmero é suficiente para aumentar a solubilização do carbonato de magnésio do calcário, que ocorre no primeiro ano de reação do gesso no decorrer de sua passagem pelos primeiros $40 \mathrm{~cm}$ do solo.

Trabalhos recentes (Cakmak, 2013) tem apresentado importante função do $\mathrm{Mg}^{2+}$ no desenvolvimento de raízes para a cultura do trigo, onde restrições e declínio da superfície radicular foram causadas devido a deficiência desse nutriente, causando impactos negativos na absorção de água pelas raízes, especialmente sob condições de limitação de água e deficiência de nutrientes no solo.

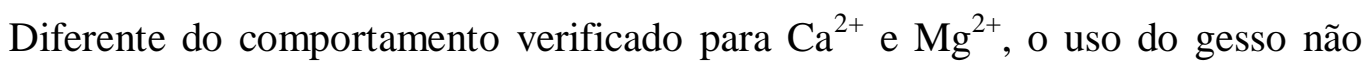
alterou os teores de $\mathrm{K}^{+}$no solo (Figura 5.7c). Assim, não foi verificada a lixiviação do $\mathrm{K}^{+}$ocasionada pelo gesso na camada de $0-100 \mathrm{~cm}$ de solo, apesar de trabalhos relatarem a possível lixiviação desse nutriente para camadas de solo fora do alcance do sistema radicular (Raij, 2008).

A não lixiviação do $\mathrm{K}^{+}$, mesmo após 50 meses da aplicação de gesso, provavelmente está associada à aplicação da dose recomendada para esse solo (Sousa \& Lobato, 2004). Além disso, o adequado desenvolvimento do sistema radicular no perfil, proporcionando maior exploração da água disponível no solo, o que favorece a absorção de nutrientes, como o $\mathrm{K}^{+}$, pode ter contribuído para o aumento na ciclagem de nutrientes nas sucessivas socas de cana-de-açúcar, evitando a lixiviação desse nutriente.

$\mathrm{O}$ enxofre no solo foi o nutriente mais beneficiado pelo uso do gesso. Com o uso desse produto os teores de $\mathrm{S}_{-} \mathrm{SO}_{4}{ }^{2-}$ se elevaram em todas as camadas de solo (Figura 5.7d). O maior incremento de ${\mathrm{S}-\mathrm{SO}_{4}}^{2-}$ foi encontrado na camada de $40-60 \mathrm{~cm}$ de solo (1 $\mathrm{cmol}_{\mathrm{c}} \mathrm{dm}^{-3}$ ), com teores 7 e 4 vezes maiores em relação às camadas de 0-20 e 20-40 cm, respectivamente, no tratamento sob uso de gesso. Isso demonstra a movimentação do S$\mathrm{SO}_{4}{ }^{2-}$ no perfil do solo, após 50 meses, tendo recebido um total de $5535 \mathrm{~mm}$ de precipitações, sendo $514 \mathrm{~mm}$ sob a forma de irrigação suplementar e $5021 \mathrm{~mm}$ de precipitações pluviométricas. Movimentação semelhante de $\mathrm{SO}_{4}{ }^{2-}$ pode ser verificada em Ritchey et al. (1995), após 4577 mm. 
A movimentação do $\mathrm{S}_{-} \mathrm{SO}_{4}{ }^{2-}$ provavelmente foi favorecida pela correção no $\mathrm{pH}$

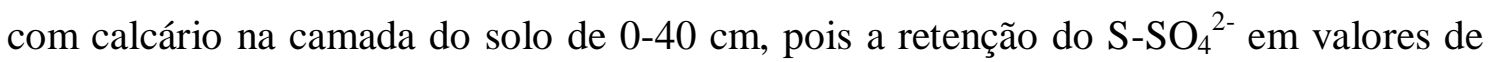
pH acima de 5,5 é mínima (Sousa \& Ritchey, 1985). Já nas camadas com maior acidez e menores teores de matéria orgânica $(40-100 \mathrm{~cm})$ o S-SO${ }_{4}^{2-}$ é retido com maior intensidade, o que favorece o efeito residual prolongado desse insumo, quando aplicado ao solo de Cerrado (Figura 5.7d). Tal movimentação confirma a ação do gesso com um

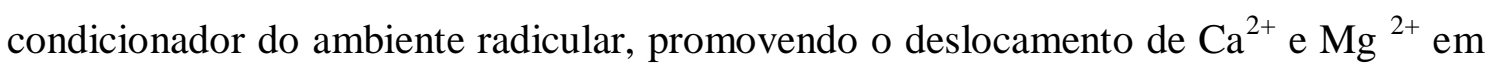
profundidade e a redução na toxidez de $\mathrm{Al}^{3+}$ (Figuras 5.6d, 5.7a e 5.7b).
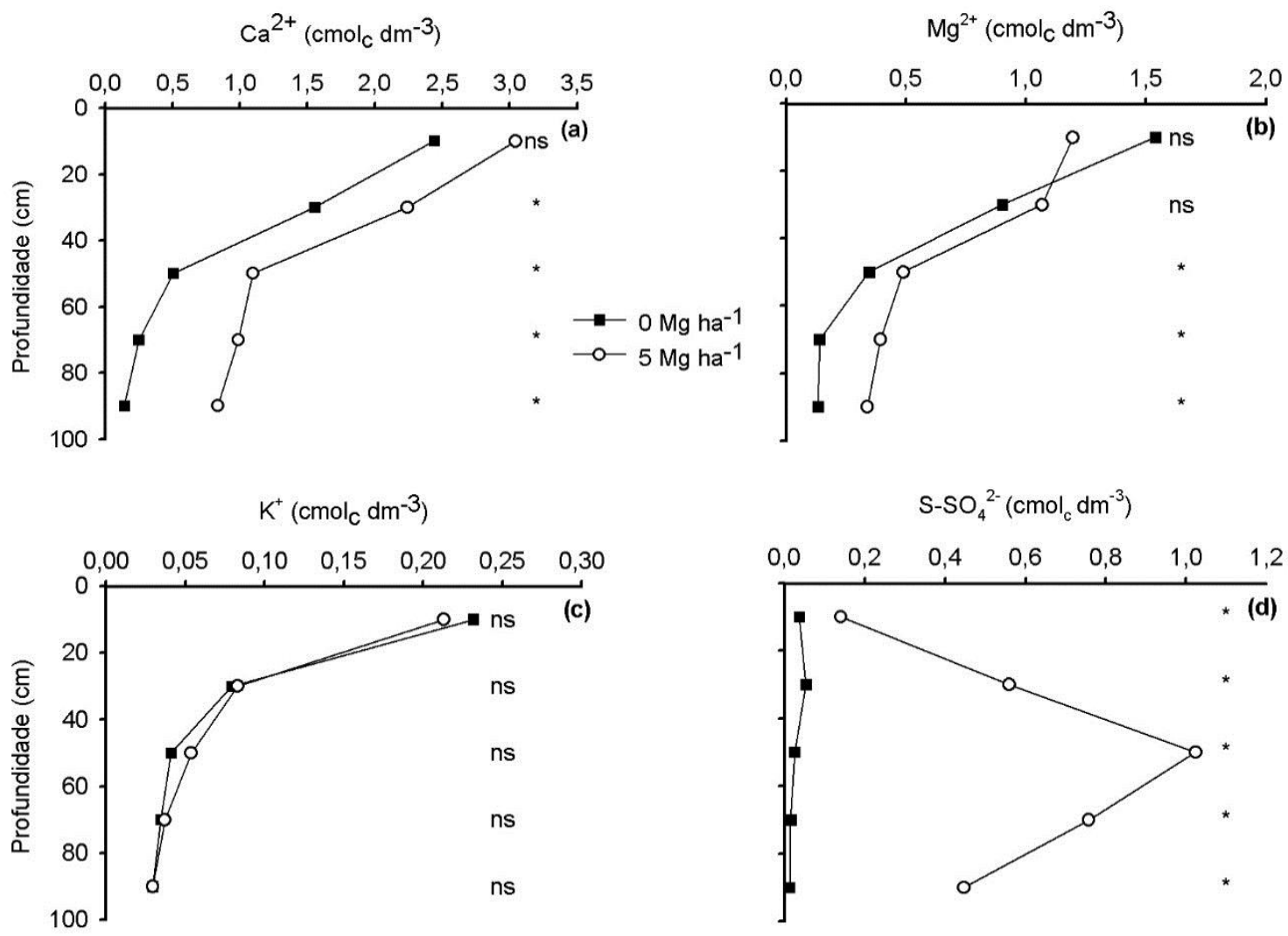

Figura 5.7: Cálcio trocável $\left(\mathrm{Ca}^{2+}\right)(\mathrm{a})$, magnésio trocável $\left(\mathrm{Mg}^{2+}\right)(\mathrm{b})$, potássio trocável

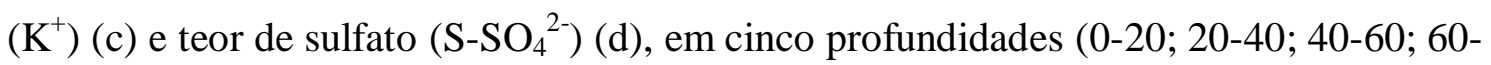
80 e 80-100 cm) de um Latossolo Vermelho, após a terceira soca em resposta a doses de gesso aplicado no plantio da cana (50 meses após aplicação). ${ }^{*}$ Significativo pelo teste $t$ $(\mathrm{p}<0,05)$.

A diferença na presença de bases $\left(\mathrm{Ca}^{2+}, \mathrm{Mg}^{2+}\right.$ e $\left.\mathrm{K}^{+}\right)$na camada de $40-100 \mathrm{~cm}$ de solo para os tratamentos com e sem gesso, foi de $2,6 \mathrm{cmol}_{\mathrm{c}} \mathrm{dm}^{-3}$ e pode ser relacionada em $82,4 \%$ pela movimentação com o $\mathrm{S}_{-} \mathrm{SO}_{4}{ }^{2-}$ (diferença entre os tratamentos foi de 2,2 
$\mathrm{cmol}_{\mathrm{c}} \mathrm{dm}^{-3}$ ), em especial com o $\mathrm{Ca}^{2+}$, seguido do $\mathrm{Mg}^{2+}$ e do $\mathrm{K}^{+}$. Os demais $17,6 \%$ de bases presentes nessa camada podem ter sidos acompanhados por ânions orgânicos, cloro, nitrato e silicato (Ritchey et al, 1980; Ziglio et al., 1999). Além disso, o extrator fosfato de cálcio monobásico $\left(0,01 \mathrm{~mol} \mathrm{~L}^{-1}\right)$ pode não ter recuperado todo sulfato lixiviado e adsorvido no solo.

A localização do pulso de $\mathrm{SO}_{4}{ }^{2-}$ na camada $20-100 \mathrm{~cm}$ e com maior intensidade entre 20-80 cm (Figura 5.7d) está de acordo com o pressuposto da recomendação de gesso para culturas perenes, baseada para adequar a camada de $20-80 \mathrm{~cm}$ do solo ao melhor desenvolvimento do sistema radicular de espécies perenes (Sousa \& Lobato, 2004).

A saturação de cálcio na CTC efetiva (saturação de $\mathrm{Ca}^{2+}$ ) foi afetada pela aplicação de gesso nas cinco camadas de solo avaliadas, sendo observados aumentos de 15, 26 e 34\% nas camadas de 40-60, 60-80 e 80-100 cm, respectivamente, em resposta à aplicação de gesso (Figura 5.8a). Já para a saturação de bases na CTC efetiva, aumentos significativos foram observados apenas nas três últimas camadas avaliadas (40-60, 6080 e $80-100 \mathrm{~cm}$ ). Tais aumentos foram proporcionados, principalmente, pela elevação nos teores de $\mathrm{Ca}^{2+}$ (Figura 5.7a) e também de $\mathrm{Mg}^{2+}$ (Figura 5.7b) e redução nos teores de $\mathrm{Al}^{3+}$ no perfil do solo (Figura 5.6c).
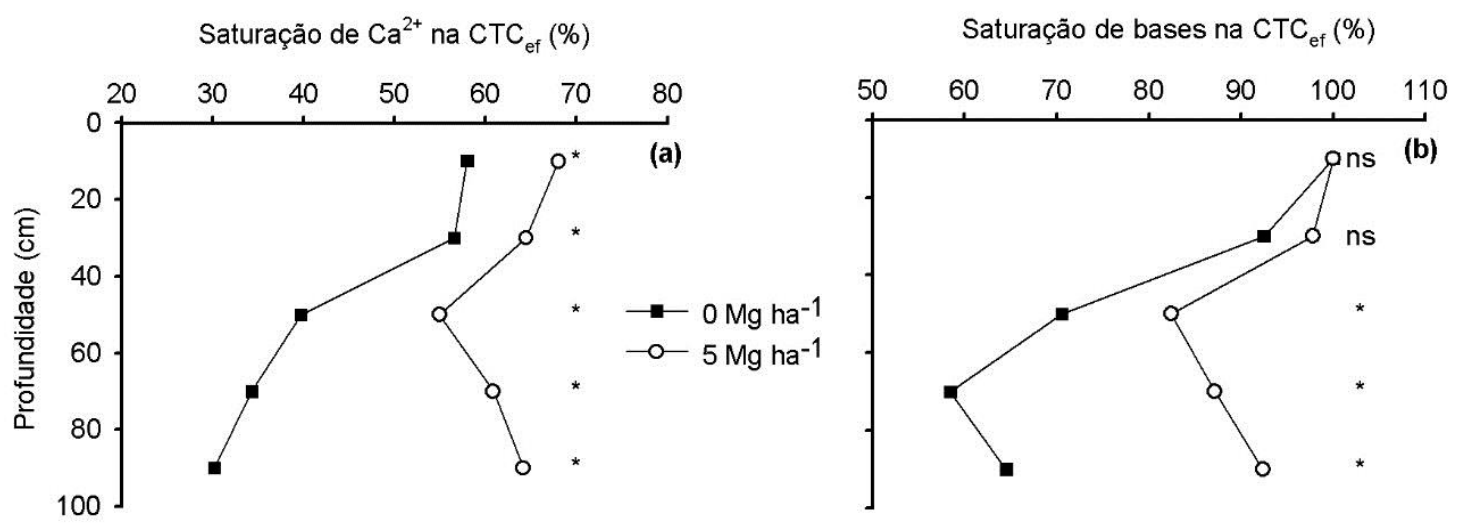

Figura 5.8: Saturação de cálcio na CTC efetiva (a) e saturação de bases na CTC efetiva (b), em cinco profundidades $(0-20 ; 20-40 ; 40-60 ; 60-80$ e 80-100 cm) de um Latossolo Vermelho, após terceira soca em resposta a doses de gesso aplicado no plantio da cana (50 meses após aplicação). *Significativo pelo teste $t(\mathrm{p}<0,05)$.

Como verificado por Sousa et al. (1992), são necessários valores maiores que 60 e $75 \%$ para a saturação de $\mathrm{Ca}^{2+}$ e saturação por bases na CTC efetiva, respectivamente, 
no perfil do solo, para que não ocorra restrição no crescimento do sistema radicular. Assim a aplicação de $5 \mathrm{Mg} \mathrm{ha}^{-1}$ de gesso foi eficiente e possibilitou a obtenção desses teores (Figura 5.8a e 5.8b), inclusive nas camadas de 20-40 e 40-60 cm de solo, para saturação de $\mathrm{Ca}^{2+}$.

Outra consequência importante do aumento de cátions de caráter básico como

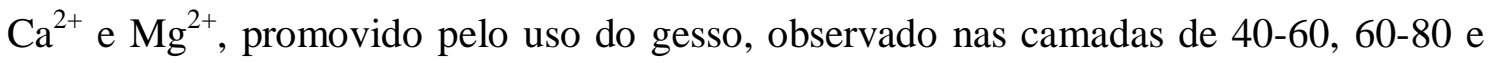
80-100 cm, foi a elevação da capacidade de troca catiônica à pH 7 (CTC pH 7) do solo que apresentou incrementos significativos de 16,9;25,2 e 22,0\%, respectivamente (Figura 5.9a). Isso representou um acréscimo de 3,28 $\mathrm{cmol}_{\mathrm{c}} \mathrm{dm}^{-3}$ na CTC $\mathrm{pH} 7$ para a camada de 40-100 cm, para o tratamento com gesso em relação a não aplicação desse insumo. De forma semelhante, ocorreram incrementos significativos para a matéria orgânica facilmente oxidável (MO) do solo (Figura 5.9b) de 12,4; 12,2 e 12,1\% nas mesmas camadas citadas devido ao uso de gesso.

Este fato de geração de cargas negativas no solo do Cerrado, em especial em camadas mais profundas, é de grande relevância na retenção de cátions, pois a fração mineral desses solos contribui pouco para a CTC a $\mathrm{pH} 7$, por tratar-se de argilas de baixa atividade. Assim, a matéria orgânica tem um papel importante na geração dessas cargas, sendo responsável por representando de 75 a 93\% da CTC a pH 7(Raij, 1969; Sousa \& Lobato, 2004, Dobbss et al., 2008).

Para que ocorra aumento de MO do solo, como observado com aplicação do gesso nas camadas 40-60, 60-80 e 80-100 cm (Figura 5.9b) é necessário introduzir biomassa vegetal de raízes. Nesse contexto, o gesso representa uma tecnologia importante, pois além de aumentar a quantidade de raízes no solo, melhora sua distribuição para camadas mais profundas, em especial na cana-de-açúcar que produz grande quantidade de biomassa (Morelli et al. 1992; Rocha et al., 2008). Isso pode favorecer também a atividade dos micro-organismos nessas camadas, promovendo maior ciclagem de nutrientes.

Uma das formas de avaliar a contribuição de MO do solo na geração de cargas negativas é através da relação entre seus teores e a CTC a pH 7. Na Figura 5.10 essa relação é apresentada com dados obtidos dos dois tratamentos em todas as profundidades. Através dessa relação é possível estimar que o acréscimo de $1 \%$ no teor de MO do solo geraria 3,306 $\mathrm{cmol}_{\mathrm{c}} \mathrm{dm}^{-3}$ de cargas negativas no solo. 
Dados obtidos por Nunes et al. (2008) em solo argiloso para relação entre MO associada a minerais e CTC a pH 7, cultivado com soja e milho em sistema de plantio direto por dez anos, para camadas de solo até $60 \mathrm{~cm}$ de profundidade, apresentaram um coeficiente angular de 3,409 $\left(\mathrm{R}^{2}=0,976\right)$, semelhante ao obtido com os dados de solo cultivado com cana-de-açúcar (Figura 5.10). Com isso, pode-se inferir pela similaridade dos coeficientes angulares, que as cargas geradas pela MO na área com culturas anuais e cana-de-açúcar foram semelhantes.

Na Figura 5.10 é observada a formação de dois grupos de dados para a relação entre a $\mathrm{MO}$ e a CTC. O grupo com maiores teores de MO, variando de 2,04\% a 2,58\% são das camadas de solo de $0-20$ e $20-40 \mathrm{~cm}$, enquanto que o grupo com menores teores (0,97 a 1,56\% de MO) são das camadas mais profundas (40-60, 60-80 e 80-100 cm). A explicação para esse comportamento pode estar associada ao preparo do solo profundo com arado de aiveca e à característica da cultura da cana-de-açúcar, cujas raízes ocorrem em maiores quantidades nas camadas mais superficiais do solo, contribuindo assim para maior acúmulo de MO. Dados de Smith et al. (2005) corroboram essa observação, onde o sistema radicular da cana-de-açúcar apresenta-se 50\% e $85 \%$ concentrados nos primeiros $20 \mathrm{~cm}$ e $60 \mathrm{~cm}$, respectivamente, podendo dessa forma favorecer o maior incremento de matéria orgânica nessas camadas do solo.
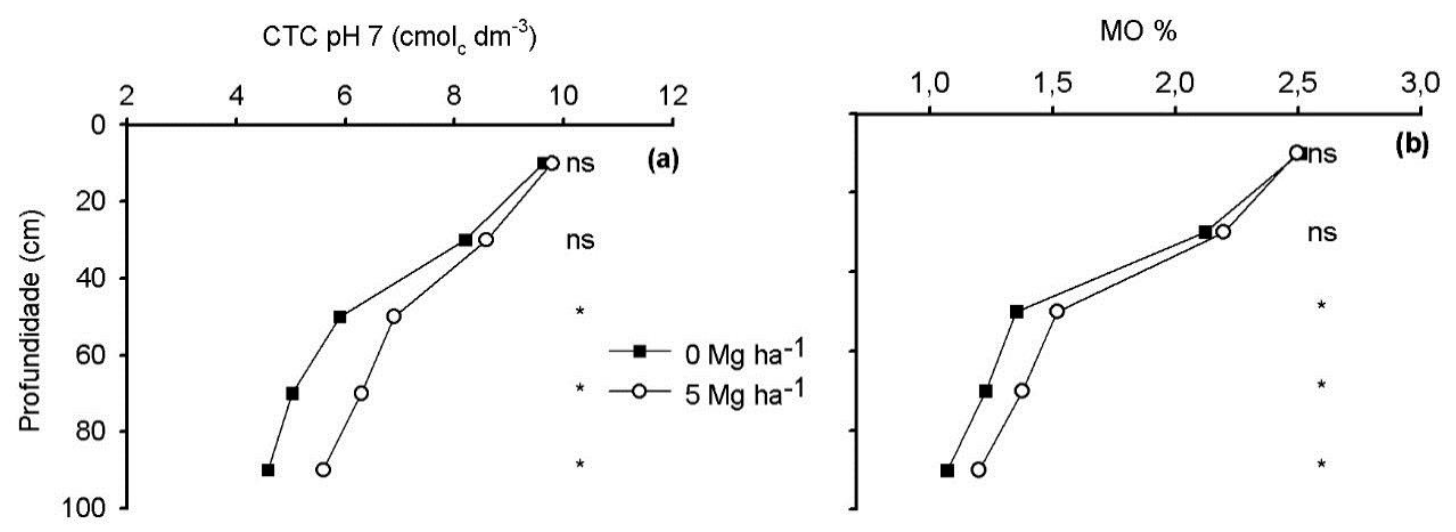

Figura 5.9: Capacidade de troca catiônica à pH 7 (CTC pH 7) (a) e matéria orgânica facilmente oxidável do solo (MO) (b), em cinco profundidades $(0-20 ; 20-40 ; 40-60 ; 60$ 80 e 80-100 cm) de um Latossolo Vermelho, após cultivo de cana-de-açúcar terceira soca em resposta a doses de gesso aplicado no plantio da cana (50 meses após aplicação). * Significativo pelo teste $t(\mathrm{p}<0,05)$. 


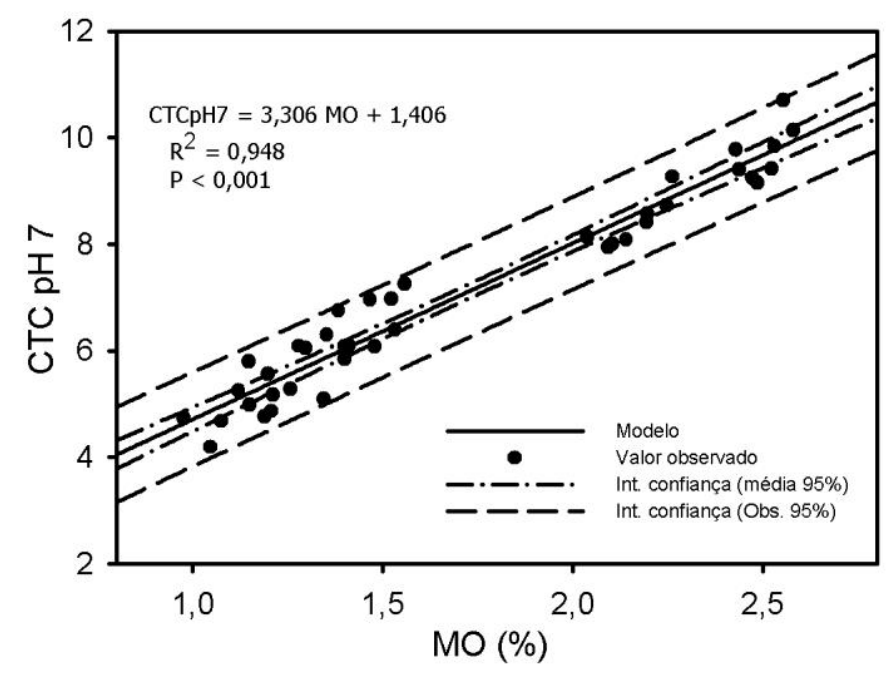

Figura 5.10: Relação entre os teores de matéria orgânica facilmente oxidável (MO) e a CTC (pH 7), de um Latossolo Vermelho na camada 0-100 cm, obtidos após a colheita da terceira soca de cana-de-açúcar com e sem a aplicação de gesso (50 meses após aplicação).

Apesar dos menores valores de MO terem sido observados nas camadas mais profundas do solo, os maiores incrementos relativos desses valores, ocorreram nas camadas (40-60, 60-80 e 80-100 cm), onde o gesso atuou. Assim, acréscimo médio de 12,2\% no teor de MO ocorreu nessas camadas, devido à aplicação do gesso, enquanto que nas camadas mais superficiais $(0-20$ a $20-40 \mathrm{~cm})$ o acréscimo médio foi de 1,5\%.

Portanto, com aplicação do gesso, os ganhos médios relativos de MO, das camadas mais profundas do solo, foram oito vezes maiores do que nas camadas superficiais, em relação a não aplicação dessa tecnologia.

\subsection{CONCLUSÕES}

1. O uso do gesso proporcionou aumento na produtividade de colmos e de açúcares redutores totais da cana-de-açúcar em quatro ciclos de cultivos sucessivos.

2. Em camadas mais profundas do solo $(40-100 \mathrm{~cm})$ os valores de $\mathrm{pH}$ em $\mathrm{CaCl}_{2}$ foram maiores e a saturação de $\mathrm{Al}^{3+}$ reduzida com o uso do gesso na cana-de-açúcar.

3. O gesso promoveu incremento de matéria orgânica e da capacidade de troca de cátions nas camadas subsuperficiais do solo, de 40-100 cm. 


\subsection{REFERÊNCIAS BIBLIOGRÁFICAS}

BALL-COELHO, B.; SAMPAIO, E.V.S.B.; TIESSEN, H.; STEWART, J.W.B. Root dynamic in plant and ratoon crops of sugarcane. Plant and Soil, Dordrecht, v. 142, n.2, p. 297-305, 1992.

BASNAYAKE, J.; JACKSON, P.A.; INMAN-BAMBER, N.G.; LAKSHMANAN, P. Sugarcane for water-limited environments. genetic variation in cane yield and sugar content in response to water stress. Journal of Experimental Botany, Oxford, v.63, n.16, p.6023-6033, 2012.

BATTIE-LACLAU, P. \& LACLAU, J.P. Growth of the whole root system for a plant crop of sugarcane under rainfed and irrigated environments in Brazil. Field Crops Research, Amsterdan, v. 114, n.3, p. 351-360, 2009.

CAIRES, E.F.; BLUM, J.; BARTH, G.; GARBUIO, F.J.; KUSMAN, M.T. Alterações químicas do solo e resposta da soja ao calcário e gesso aplicados na implantação do sistema plantio direto. Revista Brasileira de Ciência do Solo, Viçosa, v.27, p.275-286, 2003.

CAIRES, E.F.; CHURKA, S.; GARBUIO, F.J.; FERRARI, R.A.; MORGANO, M. A. Soybean yield and quality a function oflime and gypsum applications. Scientia Agricola, Piracicaba, v.63, n.4, p.370-379, 2006.

CAIRES, E.F.; FELDHAUS, I.C.; BLUM, J. Crescimento radicular e nutrição da cevada em função da calagem e aplicação de gesso. Bragantia, Campinas, v.60, n.3, p.213-223, 2001.

CAKMAK, I. Magnesium in crop production, food quality and human health. Plant and Soil, v. 368, n. 1-2, p. 1-4, 2013.

COCHRANE, T.T. \& AZEVEDO, L.G. As savanas do trópico sul-americano; uma visão geral dos seus recursos de clima e solo para desenvolvimento agrotecnológico baseada no inventário computadorizado de sistemas de terra do CIAT/EMBRAPA. In: SIMPÓSIO SOBRE O CERRADO, 6., Brasília, 1982. Savanas: alimento e energia. Brasília, EMBRAPA-DDT, 1988, Prelo. 
COCHRANE, T.T. PORRAS, J.A.; HENAO, M.R. The relative tendency of the cerrados to be affected by veranicos. A provisional assessment. In: SIMPÓSIO SOBRE O CERRADO, 6, 1982, Brasília. Anais... Planaltina: EMBRAPA-CPAC, 1988. p. 229238.

COMPANHIA NACIONAL DE ABASTECIMENTO - CONAB. Séries Históricas Relativas às Safras 2005/06 a 2014/15 de Área Plantada, Produtividade, Produção, Áçucar, Etanol total, Etanol anidro e Etanol hidratado. Disponível em: < http://www.conab.gov.br/conteudos.php?a=1252\&t=\&Pagina_objcmsconteudos=2\#A_o bjcmsconteudos >. Acesso em: 16 de Janeiro, 2015.

CONSECANA. Conselho dos Produtores de Cana-de-Açúcar, Açúcar e Álcool do Estado de São Paulo. Manual de instruções. 5. ed. Piracicaba-SP, 2006. 111p.

DEMATTÊ, J.L.I.; PAGGIARO, C.M.; BELTRAME, J.A.; RIBEIRO, S.S. Uso de silicatos em cana-de-açúcar. Informações Agronômicas, Piracicaba, v.133, p.7-12, 2011.

DOBBSS, L.; ALLEONI, L.R.F.; VELlOSO, A.C.X.; CANELLAS, L.P. Eletroquímica de Latossolos brasileiros após a remoção da matéria orgânica humificada solúvel. Revista Brasileira de Ciência do Solo, Viçosa, v.32, p.985-996, 2008.

EMBRAPA. Centro Nacional de Pesquisa de Solos. Manual de métodos de análise de solos. 2 ed. Rio de Janeiro, 1997. 212 p.

EMPRESA DE PESQUISA ENERGÉTICA - EPE. Balanço energético nacional 2013, I Relatório Síntese I ano base 2012. Disponível em: < http://ben.epe.gov.br/downloads/S\%C3\%ADntese \%20do\%20Relat\%C3\%B3rio\%20Fin al_2013_Web.pdf >. Acesso em: 02 de dezembro, 2014.

FOOD AND AGRICULTURE ORGANIZATION OF THE UNITED NATIONS FAOSTAT. Countries by commodity top production sugarcane - 2012. Disponível em: < http://faostat.fao.org/site/339/default.aspx >. Acesso em: 05 de dezembro, 2014. HERNANDES, T.A.D., BUFON, V.B.; SEABRA, J.E. Water footprint of biofuels in Brazil: assessing regional differences. Biofuels, Bioproducts and Biorefining, v.8, n.2, p.241-252, 2014. 
LEE, J. \& MUDGE, K.W. Water deficit affects plant and soil water status, plant growth, and ginsenoside contents in American ginseng. Horticulture, Environment, and Biotechnology, Jangan-gu, v.54, n.6, p.475-483, 2013.

LIMA, R.C.; MELLO, L.M.; YANO, É.H.; SILVA, J.O.; CESARIN, A.L. Modalities for soil preparation and gypsum application in ultisol: stem productivity of sugarcane. Engenharia Agrícola, Jaboticabal, v.33, n.6, p.1180-1190, 2013.

LOPES, A.S.; GUIMARÃES, G.L.R.; RAMOS, S.J. The Saga of the Agricultural Development of the Brazilian Cerrado. International Potash Institute, n.32, p.29-37, 2012.

MACHADO, R.S.; RIBEIRO, R.V.; MARCHIORI, P.E.R.; MACHADO, D.F.S.P.; MACHADO, E.C.; LANDELL, M.D.A. Respostas biométricas e fisiológicas ao déficit hídrico em cana-de-açúcar em diferentes fases fenológicas. Pesquisa Agropecuária Brasileira, Brasília, v.44, n.12, p.1575-1582, 2009.

MAHAN, B.M. \& MYERS, R.J. Química: um Curso Universitário. Trad. de H.E. Toma et al. São Paulo: Edgard Blücher, 1995.

MALAVOLTA, E.; VITTI, G. C.; OLIVEIRA, S. A. Avaliação do estado nutricional das plantas: princípios e aplicações. 2.ed. Piracicaba: Associação Brasileira para Pesquisa da Potassa e do Fosfato, 1997. 319 p.

MARSCHNER, H. Marschner's mineral nutrition of higher plants. 1.ed. P. Marschner Academic press, 2012.

MINISTÉRIO DE MINAS E ENERGIA - MME. Boletim mensal dos combustíveis renováveis, janeiro/2014. Disponível em: < http://biomercado.com.br/imagens/publicacao/arquivo91.pdf $>$. Acesso em: 02 de dezembro, 2014.

MORELLI, J.L.; DALBEN, A.E.; ALMEIDA, J.O.C.; DEMATTÊ, J.L.I. Calcário e gesso na produtividade da cana de açúcar e nas características químicas de um Latossolo de textura média Álico. Revista Brasileira de Ciência do Solo, Viçosa, v.16, p.187-194, 1992.

MORELLI, J.L.; NELLI, E.J.; DEMATTÊ, J.L.I.; DALBEN, A.E. Efeito do gesso e do calcário nas propriedades químicas de solos arenosos álicos e na produção de cana-deaçúcar. STAB: Açúcar, Álcool e Subprodutos, v.6, n.2, p.24-31, 1987. 
NORA, D.D. \& AMADO, T.J.C. Improvement in Chemical Attributes of Oxisol Subsoil and Crop Yields under No-Till. Agronomy Journal, Madison, v.105, n.5, p.1393-1403, 2013.

NUNES, R.S.; SOUSA, D.M.G.; GOEDERT, W.J. \& SOARES, J.R.R. Impacto dos sistemas de plantio direto e preparo convencional nas interações entre matéria orgânica e fertilidade do solo. In: SIMPÓSIO NACIONAL DO CERRADO, 9.; SIMPÓSIO INTERNACIONAL DE SAVANAS TROPICAIS, 2., 2008, Resumos... Planaltina: Embrapa Cerrados, 2008. CD ROM

OLIVEIRA, E.C.A. Balanço nutricional da cana-de-açúcar relacionado à adubação nitrogenada. 2011. 213p. Tese (Doutorado em Solos e Nutrição de Plantas) - Escola superior de Agricultura “Luiz de Queiroz”, ESALQ, Piracicaba, 2011.

OTTO, R. Desenvolvimento radicular e produtividade da cana-de-açúcar relacionados à mineralização do $\mathbf{N}$ do solo e à adubação nitrogenada. 2012. 120f. Tese (Doutorado em Solos e Nutrição de Plantas) - Escola Superior de Agricultura Luiz de Queiroz, USP, Piracicaba, 2012.

PAULETTI, V.; PIERRI, L.D.; RANZAN, T.; BARTH, G.; MOTTA, A.C.V. Longterm effects of the application of gypsum and lime in a no-till system. Revista Brasileira de Ciência do Solo, Viçosa, v.38, n.2, p.495-505, 2014.

PAVAN, M. A.; VOLKWEISS, S. J. Efeitos do gesso nas relações solo - planta: princípios. In: SEMINÁRIO SOBRE O USO DO FOSFOGESSO NA AGRICULTURA, 1985, Brasília. Anais... EMBRAPA-SPI, 1986. p. 107-118.

RAIJ, B.van. A capacidade de troca de cátions das frações orgânica e mineral em solos. Bragantia, Camipinas, v. 28, n. único, p. 85-112, 1969.

RAIJ, B. van. Reações de gesso em solos ácidos. In: SEMINÁRIO SOBRE O USO DO GESSO NA AGRICULTURA,Uberaba, 1992. Anais... Uberaba. p.105-119.

RAIJ, B.van. Gesso na agricultura. Campinas, Instituto Agronômico, 2008. 233p.

RAMPIM, L.; LANA, M.C.; FRANDOLOSO, J.F. Fósforo e enxofre disponível, alumínio trocável e fósforo remanescente em Latossolo Vermelho submetido ao gesso cultivado com trigo e soja. Semina: Ciências Agrárias, Londrina, v.34, n.4, p.1623$1638,2013$. 
RAMPIM, L.; LANA, M.D.C.; FRANDOLOSO, J.F.; FONTANIVA, S. Chemical attributes of a soil and response of wheat and soybean to gypsum in no-tillage system. Revista Brasileira de Ciência do Solo, Viçosa, v.35, n.5, p.1687-1698, 2011.

REEVE, N.G. \& SUMNER, M.E. Amelioration of subsoil acidity in Natal oxisols by leaching of surfasse-applied amendmeents. Agrochemophysica, Pretoria, v.4, n.1, p.1$6,1972$.

REIN, T.A. Surface chemical properties and nitrato adsorption of oxisols from the brazilian savanas. 2008. 509f. Tese (Doutorado em Ciência do Solo) - Faculty of the Graduate school, Cornell University, Ithaca, 2008.

RITCHEY, K. D., SOUZA, D. M., LOBATO, E., \& CORREA, O. Calcium leaching to increase rooting depth in a Brazilian Savannah Oxisol. Agronomy Journal, Madison, v.72, n.1, p.40-44, 1980.

RITCHEY, K.D., FELDHAKE, C.M., CLARK, R.B. \& SOUSA, D.M.G. Improved water and nutrient uptake from subsurface layers of gypsum-amended soils. In: J. L.Karlan, R. J. Wright \& W.D. Kemper (Eds.). Agricultural utilization of urban and industrial by-products. Madison: American Society of Agronomy, 1995. p. 157-181.

RITCHEY, K.D.; SILVA, J.E.; SOUSA, D.M.G. Lixiviação de cálcio e crescimento de raízes em solos de cerrados. In: CONGRESSO BRASILEIRO DE CIÊNCIAS DO SOLO, 18., 1981, Salvador. Resumos... p.96.

ROCHA, A.T.; OLIVEIRA, A.C.; RODRIGUES, Á.N.; LIRA JÚNIOR, M.A.; FREIRE, F.J. Emprego do gesso do Araripe na melhoria do ambiente radicular da canade-açúcar, Revista Brasileira de Ciências Agrárias, Recife, v.3, n.4, p.307-312, 2008.

SANTOS, R.L.; FREIRE, F.J.; AZEVEDO, V.M.; ROCHA, A.T.; TAVARES, J.A. Produção de capim elefante e movimentação de cátions em função de gesso mineral. Revista Brasileira de Engenharia Agrícola e Ambiental, Campina Grande, v.17, n.10, p.1030-1037, 2013.

SCHOFIELD, R. K., \& TAYLOR, A. W. The measurement of soil pH. Soil Science Society of America Journal, Madison, v.19, n.2, p.164-167, 1955.

SERAFIM, M.E., DE LIMA, J.M., LIMA, V.M.P., ZEVIANI, W.M.; PESSONI, P.T. Alterações físico-químicas e movimentação de íons em Latossolo gibbsítico sob doses de gesso. Bragantia, Campinas, v.71, n.1, p.75-81, 2012 
SMITH, D.M.; INMAN-BAMBER, N.G.; THORBURN, P.J. Growth and function of the sugarcane root system. Field Crops Research, v.92, n.2, p.169-183, 2005.

SOUSA, D.M.G \& RITCHEY, K,D. Uso do gesso no solo de Cerrados. In: SEMINÁRIO SOBRE O USO DEFOSFOGESSO NA AGRICULTURA, 1985, Brasília. Anais... p.119-144

SOUSA, D.M.G. \& LOBATO, E. Cerrado: correção do solo e adubação. Planaltina: Embrapa Cerrados, 2004.

SOUSA, D.M.G. \& REIN, T.A. Manejo da fertilidade do solo para culturas anuais: experiências no cerrado. Informações Agronômicas, IPNI, Piracicaba, n.126, p.1-7, 2009.

SOUSA, D.M.G.; LOBATO, E.; REIN, T. A. Uso do gesso agrícola nos solos do Cerrado. Circular Técnica Embrapa Cerrados, Brasília, v. 32, 2005.

SOUSA, D.M.G.; REIN, T.R.; LOBATO, E.; RITCHEY, K.D. Sugestões para a diagnose e recomendação de gesso em solos de Cerrado. In: SEMINÁRIO SOBRE O USO DO GESSO NA AGRICULTURA, 2. 1992, Uberaba. Resumos... p. 139-158.

SOUSA, D.M.G; MIRANDA, L.N.; OLIVEIRA, S.A. In: NOVAIS, R.F.; ALVAREZ V.,V. H.; BARROS, N.F.; FONTES, R.L.F.;CANTARUTTI, R.B.; NEVES, J.C.L.(Eds.). Fertilidade do solo. Viçosa: SBCS, 2007. 1017 p.

TUTEJA, N. \& MAHAJAN, S. Calcium signaling network in plants: an overview. Plant Signaling \& Behavior, v.2, n.2, p.79, 2007.

WACLAWOVSKY, A.J.; SATO, P.M.; LEMBKE, C.G.; MOORE, P.H.; SOUZA, G.M. Sugarcane for bioenergy production: an assessment of yield and regulation of sucrose content. Plant Biotechnology Journal, v.8, n.3, p. 263-276, 2010.

WALKLEY, A. \& BLACK, I.A. An examination of the Degtjareff method for determining soil organic matter and a proposed modification of the chromic acid titration method. Soil Science, v.37, n.1, p.29-38, 1934.

ZIGLIO, C.M.; MIYAZAWA, M.; PAVAN, M.A. Formas orgânicas e inorgânicas de mobilização do cálcio no solo. Brazilian Archives of Biology and Technology, Paraná, v.42, n.2, p.257-262, 1999. 
CAPÍTULO II

O USO DO GESSO AUMENTA O ESTOQUE DE CARBONO DO SOLO CULTIVADO COM CANA-DE-AÇÚCAR NO CERRADO 


\section{O USO DO GESSO AUMENTA O ESTOQUE DE CARBONO DO SOLO CULTIVADO COM CANA-DE-AÇÚCAR NO CERRADO}

\subsection{RESUMO}

Entre os benefícios da utilização do gesso em solos com alta saturação por alumínio e baixos teores de cálcio em profundidade, destaca-se o maior crescimento e distribuição do sistema radicular das culturas em camadas subsuperfíciais. Adicionalmente, as raízes são as principais responsáveis por possibilitar a incorporação de matéria orgânica no solo, portanto o uso do gesso pode favorecer o aumento do estoque de carbono no solo. Dessa forma, o objetivo desse trabalho foi avaliar o estoque de carbono total no solo e suas frações particulada e associada aos minerais, após 4 anos de cultivo com cana-deaçúcar sob uso de gesso. $\mathrm{O}$ experimento foi conduzido na área experimental localizada na Embrapa Cerrados, em Planaltina - DF. O delineamento experimental constituiu-se de blocos casualizados, com 4 repetições e dois tratamentos: testemunha $\left(0 \mathrm{Mg} \mathrm{ha}^{-1}\right) \mathrm{e}$ dose recomendada (5 $\left.\mathrm{Mg} \mathrm{ha}^{-1}\right)$. Aplicou-se o gesso a lanço na superfície do solo após o plantio da cana-de-açúcar na estação seca. A biomassa de colmos e a produção de palha foram avaliados na cana planta e em três socas. Efetuou-se a coleta de solo após avaliação da terceira soca em sete camadas $(0-5 ; 5-10 ; 10-20 ; 20-40 ; 40-60 ; 60-80$ e 80$100 \mathrm{~cm}$ ), para a determinação dos teores de carbono orgânico, carbono total, carbono particulado e densidade do solo. O uso de gesso promoveu o aumento de 5,4 $\mathrm{Mg} \mathrm{ha}^{-1}$ no estoque de carbono total (CT) no solo na camada de 0-100 cm, sendo 4,4 $\mathrm{Mg} \mathrm{ha}^{-1}$ na camada de 40-100 cm. O estoque de carbono particulado (CP) na camada de 40-100 cm aumentou em 18,4\% devido ao uso do gesso e representou $15,9 \%$ do incremento observado do estoque de CT, enquanto que o estoque de carbono associado aos minerais (CM) aumentou 6,8\% com aplicação de gesso, representando $84,1 \%$ do acréscimo no estoque de CT. Do incremento total obtido nos estoques de C devido ao uso do gesso, $80 \%$ ocorreram na camada de $40-100 \mathrm{~cm}$.

Palavras-chave: matéria orgânica do solo, carbono particulado, carbono associado aos minerais, palha de cana-de-açúcar 


\subsection{ABSTRACT}

Improvement in growth and distribution of root system in subsurface layers are among the main benefits of using gypsum in soils with high aluminum saturation and low calcium levels in depth. In addition, roots are mainly responsible by allowing the incorporation of organic matter in the soil and use of gypsum can help to increase carbon stock in soil. Thus, the aim of this study was to evaluate the total carbon stock in soil and its particulate and mineral-associated fractions, after 4 cultivation seasons of sugarcane under use of gypsum. The experiment was conducted in an experimental field of Embrapa Cerrados, in Planaltina - DF. Experimental design consisted of randomized blocks design with four replications and two treatments: control $\left(0 \mathrm{Mg} \mathrm{ha}^{-1}\right)$ and recommended dose $\left(5 \mathrm{Mg} \mathrm{ha}^{-1}\right)$. Gypsum was broadcast on the soil surface after planting of sugarcane in the winter. Sugarcane stalk biomass and straw production were evaluated in plant cane and three ratoons. Soil samples were taken after evaluation of the third ratoon in seven layers $(0-5 ; 5-10 ; 10-20 ; 20-40 ; 40-60 ; 60-80$ and 80-100 cm), for the determination of organic carbon, total carbon, particulate carbon and bulk density. Gypsum increased in $5.4 \mathrm{Mg} \mathrm{ha}^{-1}$ the total carbon stock (CT) in the 0-100 $\mathrm{cm}$ soil layer, with $4.4 \mathrm{Mg} \mathrm{ha}^{-1}$ in the layer of $40-100 \mathrm{~cm}$. Particulate carbon stock (CP) at $40-100 \mathrm{~cm}$ layer was increased by $18.4 \%$ due to use of gypsum and represented $15.9 \%$ of the increase observed in the CT stock, while the carbon stock associated to minerals (CM) increased $6.8 \%$ with gypsum applications, representing $84.1 \%$ of the increase in CT stock. From the total increase obtained in C stocks due to the use of gypsum, $80 \%$ occurred at the depth of $40-100 \mathrm{~cm}$.

Keywords: soil organic matter, particulate carbon, carbon associated to minerals, straw, sugarcane.

\subsection{INTRODUÇÃO}

O setor agropecuário e as mudanças no uso da terra devido ao desmatamento são responsáveis por aproximadamente $57 \%$ das emissões de gases do efeito estufa (GEE) no Brasil (MCTI, 2013). Conhecendo o potencial dos manejos agrícolas conservacionistas em sequestrar carbono, o governo brasileiro instituiu o Programa Agricultura de Baixo Carbono (ABC), que é composto por vários planos de ação, como a recuperação de pastagens degradadas, a maior adoção do sistema de plantio direto, 
integração lavoura-pecuária-floresta e uso da fixação biológica de nitrogênio (Maia et al., 2011).

A ampliação dos sistemas de manejo conservacionistas está diretamente associada à quantidade de dióxido de carbono $\left(\mathrm{CO}_{2}\right)$ sequestrado da atmosfera pelas plantas no processo de fotossíntese (Bayer et al., 2006; Costa et al., 2008). Sabendo que parte desse $\mathrm{C}$ será posteriormente incorporado ao solo, o cultivo de espécies perenes que possuem elevada capacidade de produção de biomassa aérea e radicular, como a canade-açúcar, favorece o sequestro de C atmosférico e seu acúmulo no solo (Carvalho et al., 2013).

A cana-de-açúcar contribui para a redução na emissão dos GEE, pois dentre os produtos obtidos durante seu processamento está a produção de etanol, que representa importante componente da matriz energética do país (Macedo et al., 2008; Santos et al., 2013). O uso do etanol reduz a utilização de combustíveis fósseis, considerados responsáveis por 30\% das emissões dos GEE no Brasil (MCTI, 2013). Além disso, o bagaço gerado durante a produção do etanol possibilita a geração de energia elétrica, tornando as usinas autossuficientes e com potencial para exportar a produção excedente, proporcionando redução nas emissões de $\mathrm{CO}_{2}$ (Chohfi et al., 2004).

Adicionalmente à redução na emissão de $\mathrm{C}$ proporcionada pelos produtos obtidos da cana-de-açúcar, destaca-se a geração de biomassa aérea e radicular. Essa cultura pode produzir de 10 a $20 \mathrm{Mg} \mathrm{ha}^{-1}$ de palha (Souza et al., 2005; Luca et al., 2008; Vitti et al., 2008) e ultrapassar $5 \mathrm{Mg} \mathrm{ha}^{-1}$ de raízes, que geralmente se concentram na camada de 0-80 cm (Landell et al., 2005) mas podem atingir seis metros de profundidade (Evans, 1936), contribuindo para o aporte de C no solo.

As raízes possuem relevante contribuição no incremento de $\mathrm{C}$ ao solo em relação à biomassa aérea (Molina et al., 2001; Rumpel \& Kögel-Knabner, 2011), devido à recalcitrância dos compostos orgânicos que predominam nos tecidos radiculares e a proteção física proporcionada pelos agregados do solo, que minimizam a mineralização do C contido no tecido radicular pela microbiota do solo (Rasse et al., 2005).

Entretanto, fatores que limitem o desenvolvimento do sistema radicular, como baixos teores de cálcio e alta saturação por alumínio (Sousa et al., 1992; Marschner, 2012), podem restringir a incorporação de C ao solo, especialmente em profundidade. Consequentemente, a adoção de práticas que tornem as condições do solo mais adequadas ao crescimento do sistema radicular em profundidade pode aumentar a incorporação de $\mathrm{C}$ ao solo e contribuir para redução de GEE na atmosfera. 
O gesso tem sido amplamente utilizado na agricultura do Cerrado brasileiro com o objetivo de fornecer nutrientes e reduzir a saturação por alumínio em profundidade, melhorando o crescimento e distribuição radicular e elevando a produtividade das culturas, com utilização mais eficiente de água e nutrientes do perfil do solo. No entanto, ainda são escassos os trabalhos que avaliam o potencial do gesso em aumentar o acúmulo de carbono em diferentes frações da matéria orgânica do solo. Portanto, o objetivo desse trabalho foi verificar se a aplicação de gesso, além de promover incremento na produtividade da cana-de-açúcar aumenta o estoque de carbono do solo em profundidade.

\subsection{MATERIAL E MÉTODOS}

\subsubsection{Descrição e manejo da Área Experimental}

O detalhamento das informações sobre a localização e caracterização da área experimental, bem como o delineamento experimental e definição dos tratamentos estudados neste capítulo, encontram-se nos itens 5.3.1 e 5.3.2 do Capítulo 1 deste trabalho.

\subsubsection{Amostragem do solo}

As amostras de solo deformadas foram coletadas em setembro de 2013, um mês após a colheita da terceira soca. Nas profundidades de 0-5 e 5-10 cm utilizou-se anel volumétrico de $100 \mathrm{~cm}^{-3}$ e $5 \mathrm{~cm}$ de diâmetro, nas demais camadas (10-20; 20-40; 40-60; 60-80 e 80-100 cm) foi utilizado o trado holandês. A coleta com anel volumétrico nas profundidades superficiais foi utilizada para evitar a contaminação das amostras nas demais profundidades, pois na camada de $0-10 \mathrm{~cm}$ é onde ocorrem os maiores teores de nutrientes e alterações das varáveis estudadas. Uma amostra composta foi obtida em cada parcela do experimento. Para cada amostra composta foram coletadas 6 subamostras, uma na linha e cinco na entrelinha, equidistantes.

A coleta das sub-amostras foi realizada buscando-se representar a heterogeneidade do sistema na linha e na entre linha de plantio, conforme ilustrado na Figura 6.1 (a e b). Para a realização das análises dos teores de carbono (orgânico, particulado e total) do solo, as amostras foram homogeneizadas, secas ao ar e passadas em peneira de malha $2 \mathrm{~mm}$. 
Para determinação da densidade do solo as amostras indeformadas foram coletadas em outubro de 2013, dois meses após a colheita da terceira soca, nas profundidades de $0-5 ; 5-10 ; 12,5-17,5 ; 27,5-32,5 ; 47,5-52,5 ; 67,5-72,5$ e 87,5-92,5 cm, com o trado de anel volumétrico de $100 \mathrm{~cm}^{-3}$ e $5 \mathrm{~cm}$ de diâmetro. Para cada parcela foram retiradas três amostras, uma na linha de plantio e duas na entre linha (Figura 6.1a e 6.1b).

Após a coleta todos os anéis foram levados para secagem em estufa à $105 \pm 3$ ${ }^{\circ} \mathrm{C}$, tomando-se, para cada profundidade, a média dos três pontos para compor o valor de densidade de cada parcela.
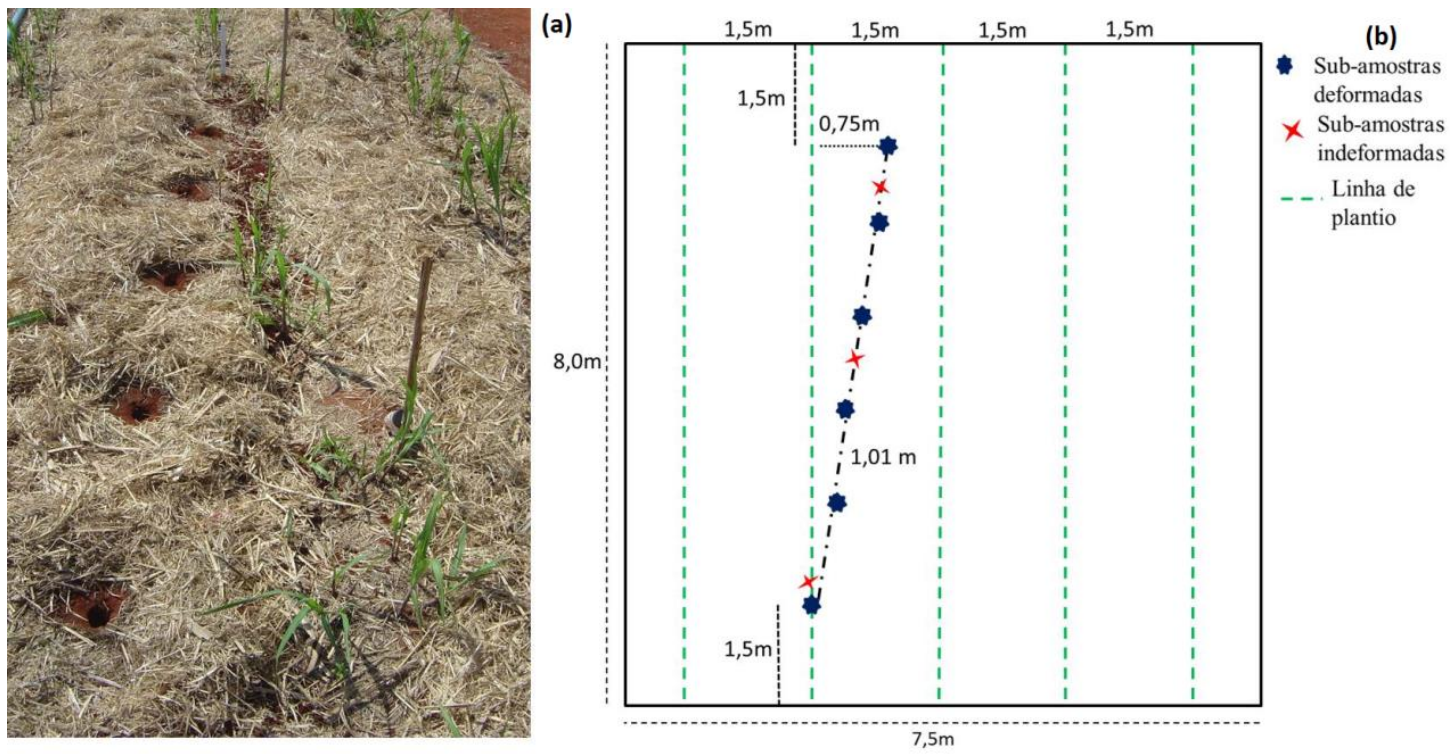

Figura 6.1: Ilustração de coleta das sub-amostras na parcela experimental. Imagem dos seis pontos de coleta das sub-amostras para a composição de uma amostra composta deformada (a) e representação esquemática dos pontos de coleta das amostras deformadas, seis pontos e das amostras indeformadas, três pontos (b).

\subsubsection{Determinação da biomassa de colmos e palha}

Os cortes da cana planta e socas foram realizados manualmente, sem despalha a fogo (cana crua). A área útil colhida consistiu das 3 linhas centrais da parcela de $5 \mathrm{~m}$ de comprimento, após exclusão de 1,5 m em cada extremidade da parcela, totalizando 22,5 $\mathrm{m}^{2}$. Foram avaliadas a produtividade total de colmos por hectare $(\mathrm{TCH})$, fibra industrial (\%) da cana-de-açúcar estimada a partir do peso do bagaço úmido prensado e de 
açúcares redutores totais (ART). Para a determinação da biomassa de colmos é efetuado a soma da fibra industrial e açúcares redutores totais, ambos em base seca (ART), conforme os protocolos do CONSECANA (2006).

Para a quantificação da palha produzida em cada corte, foi recolhida e pesada toda a palha (folhas, parte das bainhas e ponteiras) contida em $4,5 \mathrm{~m}^{2}$ da linha central da área útil, retirada uma amostra para determinar a umidade e o teor de carbono. $\mathrm{O}$ palhiço (resultante da decomposição da palha) avaliado da cana-planta, primeira e segunda soca foram determinados em $1,5 \mathrm{~m}^{2}$ na área útil da parcela uma semana antecedente a colheita de cada corte, com pesagem de toda biomassa, e retirada uma amostra para determinação da umidade e do teor de carbono.

\subsubsection{Determinação do teor e do estoque de carbono total}

Para o teor de carbono total (CT), foram retiradas das amostras de terra fina seca ao ar (TFSA) dez alíquotas com cachimbo de $1 \mathrm{~cm}^{3}$, totalizando aproximadamente $10 \mathrm{~g}$ de solo e então maceradas e passadas em peneira de malha $0,149 \mathrm{~mm}$. A partir das amostras de solo passadas em peneira $(0,149 \mathrm{~mm})$ foram pesadas aproximadamente 150 mg e colocadas em cápsulas de estanho. Os teores de CT foram determinados por combustão seca em analisador Vario Macro Cube.

Uma vez que não foi encontrada diferença significativa para a densidade do solo entre os tratamentos utilizados no presente trabalho (média ponderada das camadas de 0-5, 0-5, 5-10 e 10-20 cm representada pela camada de 0-20 cm) (Tabela 6.1), o estoque de carbono foi calculado pelo método da camada equivalente de solo, que é realizado em função da concentração do CT no solo, da espessura da camada e da densidade do solo (Ellert \& Bettany, 1995).

Tabela 6.1: Densidade do solo após o cultivo por quatro anos com cana-de-açúcar, sem e com aplicação de gesso.

\begin{tabular}{ccc}
\hline \multirow{2}{*}{ Profundidade $(\mathrm{cm})$} & \multicolumn{2}{c}{ Doses de gesso $\left(\mathrm{Mg} \mathrm{ha}^{-1}\right)$} \\
\cline { 2 - 3 } & 0 & 5 \\
\hline $0-20$ & $-----------------\mathrm{g} \mathrm{cm}^{-3}-------------$ & $1,01^{\mathrm{ns}}$ \\
$20-40$ & $0,99^{\mathrm{ns}}$ & $1,03^{\mathrm{ns}}$ \\
$40-60$ & $1,05^{\mathrm{ns}}$ & $1,06^{\mathrm{ns}}$ \\
$60-80$ & $1,04^{\mathrm{ns}}$ & $1,05^{\mathrm{ns}}$ \\
$80-100$ & $1,07^{\mathrm{ns}}$ & $1,12^{\mathrm{ns}}$ \\
\hline
\end{tabular}

${ }^{\text {ns }}$ Não significativo pelo teste $t(\mathrm{p}<0,05)$. 


\subsubsection{Determinação de carbono orgânico}

O carbono orgânico $(\mathrm{CO})$ foi determinado por oxidação via úmida com dicromato de potássio em meio sulfúrico, seguido da titulação com sulfato ferroso amoniacal sem fonte externa de calor (Walkley \& Black, 1934). Dessa forma, nas amostras de solo passadas em peneira de malha $2 \mathrm{~mm}$ foi pesado $1 \mathrm{~g}$ para essa determinação, pois nas camadas mais profundas $(40-60,60-80$ e $80-100 \mathrm{~cm})$ os teores de $\mathrm{C}$ foram menores que $9 \mathrm{~g} \mathrm{~kg}^{-1}$, e ao dobrar a massa de solo usualmente recomendada para essa determinação $(0,5 \mathrm{~g})$, foram obtidos valores com menor coeficiente de variação.

\subsubsection{Determinação do teor e do estoque de carbono particulado}

O carbono particulado $(\mathrm{CP})$ foi determinado a partir do fracionamento físico granulométrico segundo Cambardella \& Elliot (1992). Aproximadamente $20 \mathrm{~g}$ de TFSA foram colocados em frascos de $500 \mathrm{ml}$. Em seguida foram adicionados $80 \mathrm{~mL}$ de

solução de hexametafosfato de sódio $\left(5 \mathrm{~g} \mathrm{~L}^{-1}\right)$, sendo a mistura agitada por $16 \mathrm{~h}$ em agitador horizontal à 150 rpm.

Após a agitação o material foi passado em peneira de malha $53 \mu \mathrm{m}$, com auxílio de jatos de água e o material retido na peneira foi transferido para béquer com tara conhecida, e seco em estufa a $50{ }^{\circ} \mathrm{C}$. Após secos os béqueres foram pesados para posterior cálculo da fração particulada e em seguida moído em gral de ágata e passado em peneira de malha $0,149 \mathrm{~mm}$, para avaliação do teor de carbono da fração particulada. Foram pesados aproximadamente $250 \mathrm{mg}$ de solo e colocadas em cápsulas de estanho para determinação por combustão via seca em analisador Vario Macro Cube.

O estoque de carbono particulado foi calculado pelo método da camada equivalente de solo, que é realizado em função da concentração do carbono no solo, a espessura da camada e a densidade do solo (Ellert \& Bettany, 1995).

\subsubsection{Determinação do estoque de carbono associado aos minerais}

$\mathrm{O}$ estoque de carbono associado aos minerais $(\mathrm{CM})$ foi obtido pela diferença entre os valores de carbono total do solo sem dispersão química e aqueles obtidos nas frações particuladas após a dispersão de hexametafosfato de sódio $(\mathrm{CM}=\mathrm{CT}-\mathrm{COP})$. 


\subsubsection{Análise Estatística}

Para a análise de variância de biomassa de colmos, da palha e palhiço da canade-açúcar foi utilizado o seguinte modelo:

$$
\mathrm{Y}_{\mathrm{ij}}=\mu+\mathrm{B}_{\mathrm{i}}+\mathrm{T}_{\mathrm{j}}+\operatorname{erro}(\mathrm{ij})
$$

Para a análise de variância dos teores e estoques de CT, CP, CM, CO e densidade nas camadas de solo foi utilizado o seguinte modelo:

$$
\mathrm{Y}_{\mathrm{ijm}}=\mu+\mathrm{B}_{\mathrm{i}}+\mathrm{T}_{\mathrm{j}}+\text { erro (ij) }+\mathrm{C}_{\mathrm{m}}+\mathrm{TC}_{\mathrm{jm}}+\text { erro (ijm) }
$$

Onde $\mu=$ média geral dos dados; $\mathrm{B}=$ bloco $(\mathrm{i}=1,2,3,4) ; \mathrm{T}=$ tratamento $(\mathrm{j}=$ $1,2) ; \mathrm{C}=$ camada $(\mathrm{m}=1,2,3,4,5)$ foi considerado a média ponderada das camadas de 0 5, 5-10 e 10-20 cm representada pela camada de 0-20 cm; erro = erro experimental.

Análise de variância foi realizada com o PROC MIXED do software SAS 9.1 (Statistical Analysis System) e quando esta apresentou significância o teste $\mathrm{T}(\mathrm{p}<0,05)$ foi utilizado para distinção das médias.

Para a relação entre os teores de CO e a CT foi gerada uma equação de regressão linear utilizando o software SigmaPlot 10.

\subsection{RESULTADOS E DISCUSSÃO}

6.5.1. Biomassa de colmos, produção total de palha da cana-de-açúcar e carbono orgânico do solo

O uso do gesso aumentou a biomassa de colmos da cana planta e das três socas. Foram produzidas 113,5 e 132,7 $\mathrm{Mg} \mathrm{ha}^{-1}$ biomassa de colmos, sem e com aplicação de gesso, respectivamente, representando incremento total de 16,9\% (Figura 6.2a).

Comportamento semelhante foi observado para a produção de palha, onde o uso do gesso possibilitou ganhos de $17,1 \%$, obtendo-se $41,5 \mathrm{Mg} \mathrm{ha}^{-1}$ na ausência de gesso e $48,6 \mathrm{Mg} \mathrm{ha}^{-1}$ onde o gesso foi aplicado (Figura 6.2b). Assim, a produção média de palha considerando os quatro cortes foi de 10,4 e 12,2 $\mathrm{Mg} \mathrm{ha}^{-1}$ sem e com uso de gesso, respectivamente, corroborando resultados obtidos em outros trabalhos que geralmente situam-se na faixa de 10,0 a 20,0 $\mathrm{Mg} \mathrm{ha}^{-1}$ (Souza et al., 2005; Luca et al., 2008; Vitti et al., 2008).

De acordo com Cerri et al. (2011) a manutenção da palha sobre a superfície do solo após a colheita proporciona incremento médio de $1,5 \mathrm{Mg} \mathrm{C} \mathrm{ha}^{-1} \mathrm{ano}^{-1}$ na camada de 
0-30 cm, em relação à colheita com queima da palha. Há também a possibilidade de utilizar a palha da cana na geração de energia, já que em termos energéticos a palha constitui 1/3 da energia potencial da cana-de-açúcar (Santos et al., 2012).

A produção de parte aérea da cana-de-açúcar é composta pela soma da biomassa de colmos e palha em base seca e apresenta estreita relação com a formação de raízes (Smith et al., 1999). Korndörfer et al. (1989) encontraram uma relação de matéria seca de raiz sobre parte aérea que variou de 4,2 a 10,2\% para quatro variedades de cana planta. No entanto, tal relação está diretamente associada à variedade e ao corte, pois a cana soca possui tendência de obter maior ralação raiz/parte aérea quando comparada a cana planta, chegando à valores de até 16,0\% (Youkhana et al., 2014).

No presente trabalho, a produção total de parte aérea foi de $155,0 \mathrm{Mg} \mathrm{ha}^{-1}$ sem aplicação de gesso e de $181,3 \mathrm{Mg} \mathrm{ha}^{-1}$ com aplicação, portanto o uso de gesso proporcionou um incremento de $26,3 \mathrm{Mg} \mathrm{ha}^{-1}$ de biomassa. Considerando uma relação raiz/parte aérea de 7,1\% para cana planta (Korndörfer et al. 1989) e de 11,4 \% para cana soca (Otto, 2012) é esperado um incremento na produção de raízes em resposta ao uso do gesso ao longo dos quatros ciclos, o que poderá favorecer aumento no teor de matéria orgânica no solo, em especial nas camadas mais profundas nas quais ocorre a maior ação do gesso.
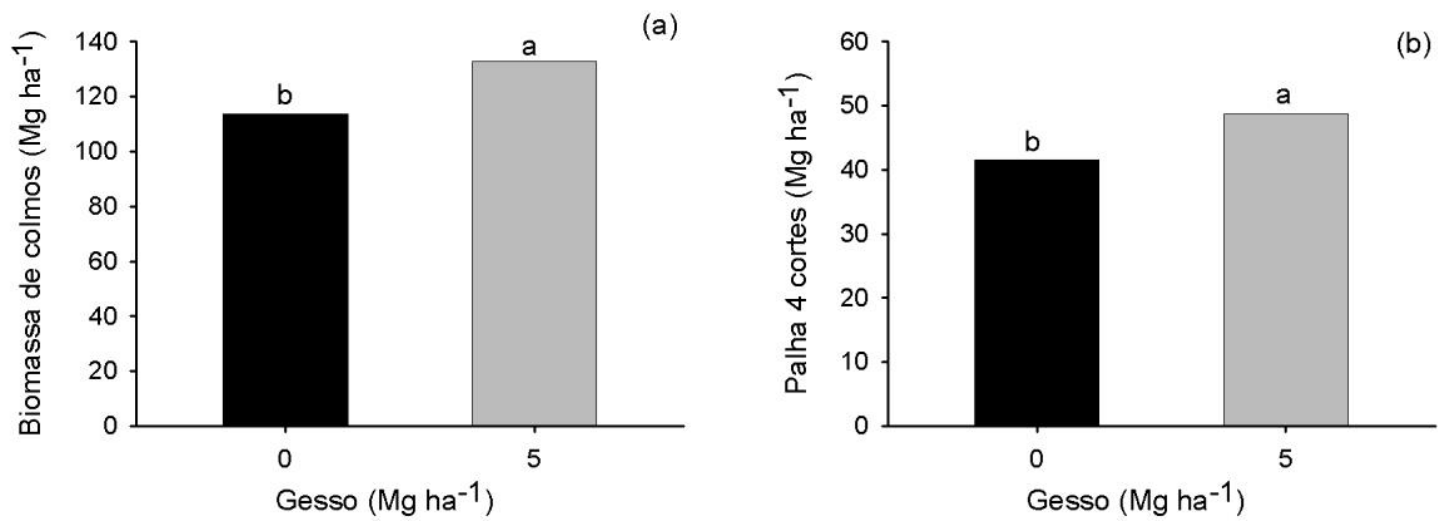

Figura 6.2: Biomassa de colmos $\left(\mathrm{Mg} \mathrm{ha}^{-1}\right)$ (a) e de palha produzida (b) em quatro cortes de cana-de-açúcar (cana planta e três socas) em resposta a doses de gesso aplicado no plantio, em Latossolo muito argiloso. *Significativo pelo teste $t(p<0,05)$.

Os teores de carbono orgânico (CO) na área antes do início do experimento (controle) variaram de 8,3 a 13,9 $\mathrm{g} \mathrm{kg}^{-1}$ (camada de 0-60 cm). Após o cultivo por quatro anos com cana-de-açúcar sem aplicação do gesso os teores obtidos variaram de 7,8 a 
$14,6 \mathrm{~g} \mathrm{~kg}^{-1}(0-60 \mathrm{~cm})$ e foram incrementados em 4,7 e 15,0\% para as camadas de 0-20 e 20-40 cm, respectivamente, não havendo aumento na camada de 40-60 cm, quando comparados com a área controle (Figura 6.3), possivelmente associado ao preparo do solo com arado de aiveca e a menor presença de raízes de cana nessa camada.

A quantidade de carbono adicionada ao solo é proporcional ao total de biomassa depositada em sua superfície e no perfil do solo na forma de raízes, que no caso de culturas anuais apresenta relação direta com a produtividade de grãos (Bayer et al., 2006; Costa et al., 2008). Assim, culturas como soja e milho com rendimento de grãos de 3,6 e 11,2 $\mathrm{Mg} \mathrm{ha}^{-1}$ fornecem em torno de 1,8 e 5,8 $\mathrm{Mg} \mathrm{C} \mathrm{ha}^{-1} \mathrm{ano}^{-1}$ (Nunes et al., 2011). No entanto, os rendimentos médios de soja e milho no Brasil estão em torno de 3,0 e 5,1 $\mathrm{Mg} \mathrm{ha}^{-1}$ (CONAB, 2015) respectivamente, o que reduz a quantidade de $\mathrm{C}$ adicionada por essas culturas.

Já para a cultura de cana-de-açúcar com rendimento médio de 72,0 $\mathrm{Mg} \mathrm{ha}^{-1}$ (cana planta e três socas) a quantidade de C aportada é de 6,5 $\mathrm{Mg} \mathrm{C}$ ha $^{-1}$ ano $^{-1}$ (Carvalho et al., 2013), valores bem superiores aos das principais culturas de grãos no Brasil, que são a soja e o milho. A produtividade média de cana-de-açúcar no Brasil é de $71,3 \mathrm{Mg}$ $\mathrm{ha}^{-1}$ (CONAB, 2015) demonstrando o alto potencial dessa cultura em acumular C no solo, mitigando os efeitos do $\mathrm{CO}_{2}$ atmosférico.

Para aumentar os teores de C no solo, além da produção de biomassa, outro importante fator é a relação existente entre raízes/parte aérea de diferentes culturas, pois a maior contribuição na adição de carbono ao solo é favorecida pelas quantidades de raízes em relação à biomassa da parte aérea (Molina et al., 2001; Rumpel \& KögelKnabner, 2011). Assim culturas que apresentam alta produção de biomassa de raízes e maior relação raízes/parte aérea tendem a favorecer o incremento de carbono ao solo, como por exemplo, a cana-de-açúcar.

O uso do gesso incrementou os teores de $\mathrm{CO}$ em 4,1; 19,2 e 6,2\% nas camadas de 0-20, 20-40 e 40-60 cm, respectivamente, em relação aos teores iniciais da área (controle) (Figura 6.3). Quando considerado o efeito do gesso na cana-de-açúcar em comparação com a não aplicação, os ganhos no CO para as camadas de maior profundidade (40-60, 60-80 e 80-100 cm) foram de 12,4; 12,2 e 12,1\%, respectivamente.

Os maiores teores de $\mathrm{CO}$ em profundidade no solo podem estar relacionados com o crescimento das raízes da cana-de-açúcar, associado ao fornecimento de $\mathrm{Ca}^{2+}$ e a redução da saturação por alumínio do solo através do uso de calcário e gesso (Rocha et 
al., 2008). Dessa forma a incorporação do calcário na camada de 0-40 cm para elevar a saturação de bases a 50\% (Figura 5.1) provavelmente favoreceu de forma similar o crescimento das raízes da cana-de-açúcar nessa camada nos dois tratamentos estudados. No entanto, a aplicação combinada de $5 \mathrm{Mg} \mathrm{ha}^{-1}$ de gesso e de calcário, possivelmente promoveu maior crescimento radicular em profundidade e consequentemente aumento nos teores de $\mathrm{CO}$.

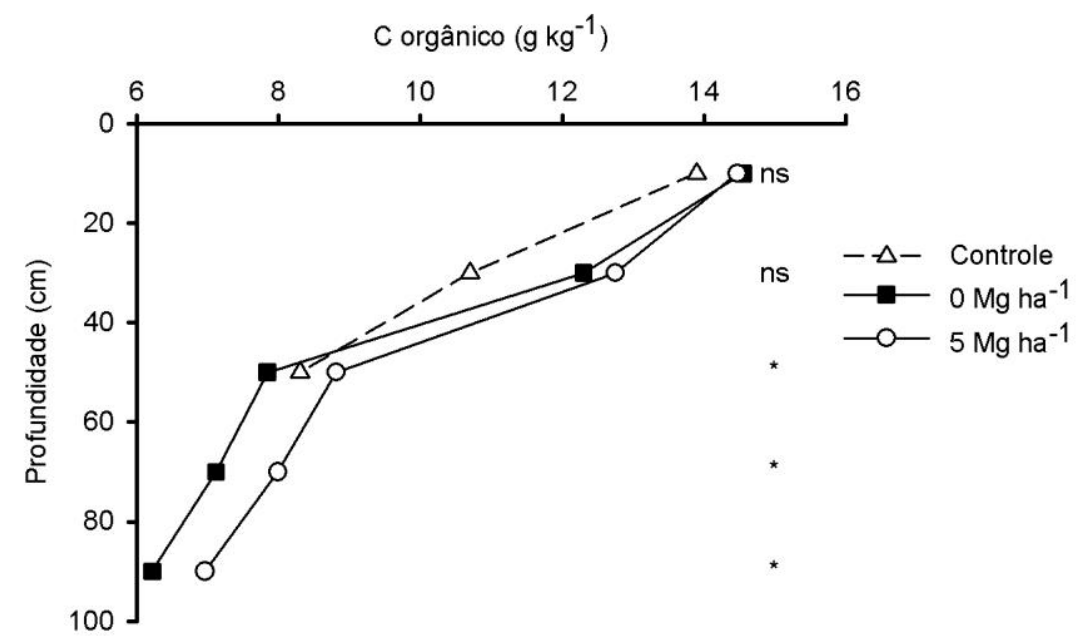

Figura 6.3: Teor de carbono orgânico (CO) nas camadas de 0-20, 20-40 e 40-60 cm antes do início do experimento (controle) e em resposta a doses de gesso aplicado no plantio de cana-de-açúcar nas camadas de 0-20, 20-40, 40-60, 60-80 e 80-100 cm após quatro cortes (50 meses após aplicação). * Significativo pelo teste t para os tratamentos 0 e $5 \mathrm{Mg} \mathrm{ha}^{-1}(\mathrm{p}<0,05)$.

Os maiores teores de $\mathrm{CO}$ no solo devido à aplicação do gesso são um bom indicativo de que o uso dessa tecnologia, além de aumentar o rendimento das culturas devido ao uso mais eficiente de água e nutrientes (Rossetto et al., 2013), pode ser uma importante aliada na mitigação do $\mathrm{C}$ atmosférico, contribuindo para minimizar os problema global dos gases de efeito estufa. Para avaliar tal efeito, se utiliza quantificar o estoque de carbono na camada do solo de 0 a $100 \mathrm{~cm}$, determinando-se o carbono total (CT) por combustão seca, pois quantifica todo o carbono do solo.

Os teores de carbono orgânico (CO) e carbono total (CT), apresentados na figura 6.4 demonstram a alta relação entre esses dois métodos, com coeficiente de correlação de 0,97 considerando a média dos tratamentos com e sem aplicação de gesso em todas as camadas avaliadas $(0-20,20-40,40-60,60-80$ e 80-100 cm). No trabalho realizado 
por Sato et al. (2014) observou-se coeficiente de correlação semelhante $(0,92)$ na comparação entre esses teores de C para amostras de solo representativas do bioma Cerrado.

Os teores de CO obtidos a partir da digestão úmida (Walkley \& Black, 1934) foram subestimados em 19,8\% em comparação com os teores de CT analisados por combustão seca (analisador elementar) (Figura 6.4). Tal fato pode estar associado à incompleta oxidação do $\mathrm{C}$ por digestão úmida, não quantificando o $\mathrm{C}$ nas formas inerte (carvão) e o protegido pela fração mineral do solo, além dos carbonatos (Segnini et al., 2008). Outra diferença dos procedimentos foi quanto à granulometria das amostras de solo, sendo que para o $\mathrm{CO}$ as amostras foram passadas em peneira de $2 \mathrm{~mm}$, enquanto que para o CT em peneira de $0,149 \mathrm{~mm}$.

A combustão seca proporciona a detecção de todas as formas de C no solo, orgânicas e inorgânicas, devido à oxidação das amostras em alta temperatura (aproximadamente $1000^{\circ} \mathrm{C}$ ). Assim, o método é considerado referência por apresentar alta precisão e exatidão nos resultados (Nelson \& Sommers, 1996; Mc Carty et al., 2010) e é, portanto, utilizado para os cálculos de estoque de C no solo (Machado, 2005).

$\mathrm{Na}$ figura 6.4 observa-se a formação de dois grupos de amostras de solo com teores maiores e menores de $\mathrm{C}$, que correspondem as camadas de 0-40 $\mathrm{cm}$ (maiores teores) e 40-100 cm (menores teores). Na camada de 0-40 cm, ocorre maior ação do calcário, com maior formação de raízes nessas camadas, além do carbono da biomassa aérea depositado na superfície do solo (Carvalho et al., 2013).

Para o grupo de amostras de solo composto pela camada de $40-100 \mathrm{~cm}$, o gesso apresenta maior atuação, conforme verificado pela movimentação de $\mathrm{S}_{-} \mathrm{SO}_{4}{ }^{2-}$ e bases (cálcio e magnésio) favorecido pela aplicação do calcário, maior teor de matéria orgânica e fertilizantes fosfatados. Já para o tratamento onde não foi aplicado gesso, o solo apresenta adversidade para bom desenvolvimento das raízes de cana em profundidade, ocasionado pela baixa mobilidade das bases (cálcio e magnésio) provenientes da dissolução do calcário, observando-se consequentemente menores valores de C. Devido a esse comportamento, para avaliar o estoque de carbono do solo considerou-se para análise estatística essas duas camadas, a de 0-40 cm e de 40-100 cm. 


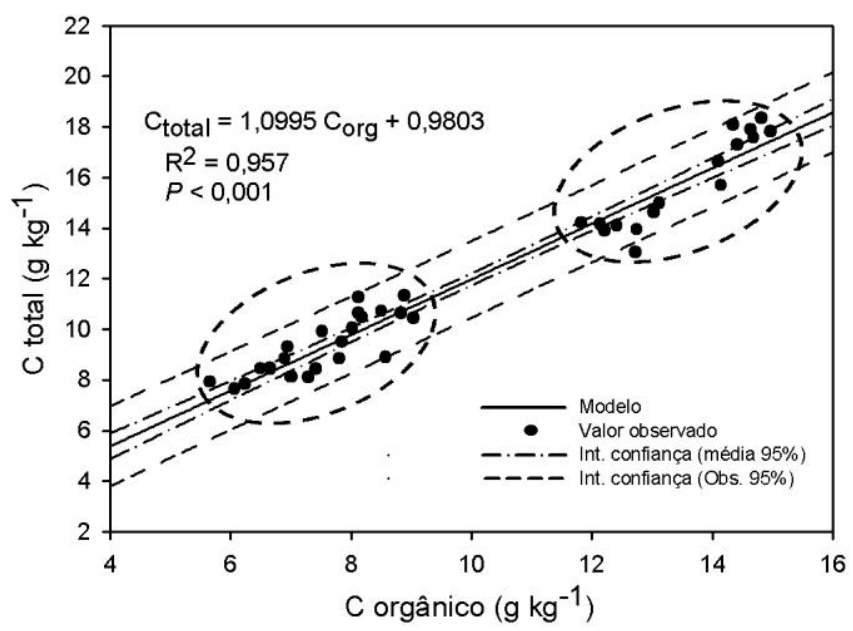

Figura 6.4: Relação entre os teores de carbono total (CT) e carbono orgânico (CO) de amostras de solo na camada de 0-100 cm. Dados obtidos após a terceira soca de canade-açúcar com e sem aplicação de gesso.

\subsubsection{Estoque de carbono no solo}

O estoque de carbono total no solo (CT) na camada de $0-40 \mathrm{~cm}$ não foi alterado pelo uso do gesso $(\mathrm{p}<0,05)$ (Fig 6.5a). Isso contrasta com o total de palha depositado a mais no tratamento com gesso na superfície do solo em quatro anos, pois significou um acréscimo de 7,1 $\mathrm{Mg} \mathrm{ha}^{-1}$ de palha, representando incremento de 17,1\% nesse tratamento em relação a não aplicação do gesso.

No intuito de entender esse comportamento, foi observado que a interação entre tratamento e profundidade foi significativa a 7,3\% ( $\mathrm{p}=0,073)$, e considerando-se esse nível de significância é possível relacionar o valor do CT estocado nas duas camadas do solo, com a quantidade de palha depositada anualmente em sua superfície. Assim, na camada de 0-20 $\mathrm{cm}$ ocorreu incremento de 2,1 $\mathrm{Mg} \mathrm{ha}^{-1}$ no estoque de CT, devido ao uso do gesso, que em parte pode ser explicado pelas $7,1 \mathrm{Mg} \mathrm{ha}^{-1}$ de palha depositadas a mais na superfície do solo durante quatro cortes da cana-de-açúcar nesse tratamento, em relação a não aplicação do gesso. Vários trabalhos, em especial comparando estoques de carbono em cana crua e cana queimada, evidenciam o benefício da palha na superfície do solo (Galdos et al., 2009; Luca et al., 2008; Carvalho et al., 2013), com acréscimos de até 1,5 $\mathrm{Mg} \mathrm{C}^{-1} \mathrm{ano}^{-1}$, na camada de 0-30 cm (Cerri et al., 2010).

Na camada 40-100 cm a aplicação do gesso promoveu aumento no estoque de CT com valores de 57,4 e $61,8 \mathrm{Mg} \mathrm{ha}^{-1}$, nos tratamentos sem e com o uso de gesso, respectivamente, representando incremento de $4,4 \mathrm{Mg} \mathrm{ha}^{-1}$ no estoque de CT (Fig 6.5b). 
Esses resultados foram semelhantes aos observados por Melo et al. (2014), que analisando o estoque de CT de 75 locais encontraram valores médios de 42,4 $\mathrm{Mg} \mathrm{ha}^{-1}$ na profundidade de 50-100 cm em áreas com cultivo de cana-de-açúcar de 5 a 20 anos no Cerrado.

$\mathrm{O}$ aumento de 4,4 $\mathrm{Mg} \mathrm{ha}^{-1}$ no estoque de CT pode estar relacionado com o efeito condicionador do gesso no perfil do solo, o qual promove maior crescimento e melhor distribuição do sistema radicular nas camadas abaixo de $40 \mathrm{~cm}$ do solo, devido ao suprimento de $\mathrm{Ca}^{2+}$ e a redução no efeito tóxico do alumínio (Rocha et al., 2008). Morelli et al. (1992) verificaram que após o uso de 5,6 $\mathrm{Mg} \mathrm{ha}^{-1}$ de gesso ocorreu incremento de 59,3\% na massa de raízes de cana-de-açúcar na camada de 0-100 cm do solo, sendo que $78,0 \%$ desse aumento foi observado na camada de $50-100 \mathrm{~cm}$.
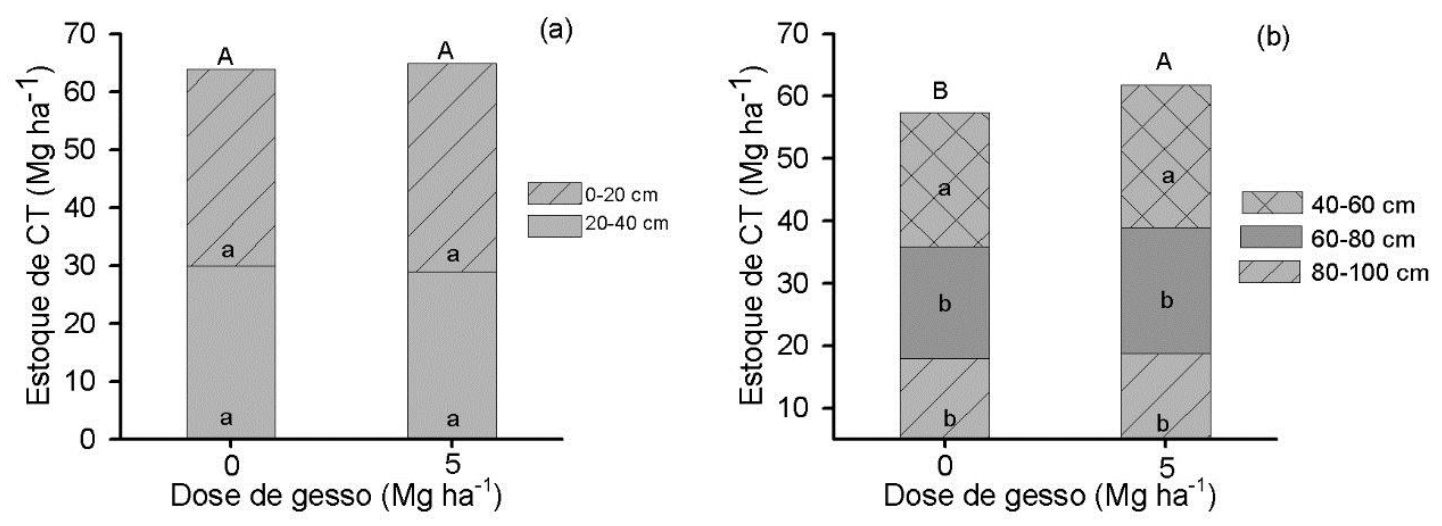

Figura 6.5: Estoque de carbono total (CT) nas profundidades de $0-20$ e $20-40 \mathrm{~cm}$ (a) e 40-60, 60-80 e 80-100cm (b) após quatro cortes de cana-de-açúcar (cana planta e três socas) em resposta a doses de gesso aplicado no plantio. Tratamentos seguidos pela mesma letra maiúscula e profundidades pela mesma letra minúscula não diferem estatisticamente pelo teste $\mathrm{t}(\mathrm{p}<0,05)$.

O incremento no estoque de CT observado na camada de 40-100 cm demonstra a importância da determinação do estoque de CT em camadas mais profundas do solo, principalmente quando relacionado com culturas perenes como a cana de açúcar, que possui raízes até seis metros de profundidade (Evans, 1936), com maior biomassa radicular ocorrendo até 1,5 metros (Smith et al., 2005). Trabalho conduzido por Newman (2014) corrobora esses dados, pois $70 \%$ do estoque de CT do solo estava contido na camada de 20-100 cm sob o cultivo com cana-de-açúcar e as maiores 
diferenças entre os tratamentos (colheita com e sem queima) foram encontradas na camada abaixo de $60 \mathrm{~cm}$ do solo.

O estoque de CT apresentado na camada de 0-100 $\mathrm{cm}$ foi de $121,3 \mathrm{Mg} \mathrm{ha}^{-1} \mathrm{e}$ $126,7 \mathrm{Mg} \mathrm{ha}^{-1}$, sem e com aplicação do gesso, respectivamente. Portanto, o uso desse insumo proporcionou o incremento de 5,4 $\mathrm{Mg} \mathrm{ha}^{-1}$, que representou ganho de 4,5\%, sendo $20 \%$ desse incremento na camada de $0-40 \mathrm{~cm}$ e $80 \%$ na camada de $40-100 \mathrm{~cm}$.

O estoque de carbono particulado $(\mathrm{CP})$ na camada de $0-40 \mathrm{~cm}$ não foi afetado pelo uso de gesso (Figura 6.6a). Ao considerar o estoque de $\mathrm{CP}$, independente do tratamento, a camada de 0-20 cm apresentou valor superior à camada de $20-40 \mathrm{~cm}$, com 4,2 e 2,4 $\mathrm{Mg} \mathrm{ha}^{-1}$, respectivamente. Dessa forma, o aporte de biomassa pela deposição de palha e raízes da cana-de-açúcar nas camadas mais superfíciais do solo, provavelmente são os principais responsáveis pelo maior estoque de CP na camada de 0-20 cm (Galdos et al., 2009).

$\mathrm{Na}$ camada de 40-100 cm o uso do gesso proporcionou maior estoque de $\mathrm{CP}$, apresentando 3,8 e 4,5 $\mathrm{Mg} \mathrm{ha}^{-1}$ sem e com aplicação desse insumo, respectivamente, o que representou ganho de 18,4\% (Figura 6.6b). Esse incremento é semelhante aos ganhos de 16,9 e $17,1 \%$ observados na biomassa de colmos e palha, respectivamente, devido ao gesso. Tal fato se justifica pela estreita relação existente entre produção de colmo, palha e raízes na cana-de-açúcar (Smith et al., 1999; Otto, 2012).

Isso pode ser avaliado através da relação percentual entre estoque de CP/CT que foi de 6,$41 ; 6,95$ e $6,48 \%$ sem aplicação de gesso e de 7,13; 7,67 e 7,01\% com uso de gesso, representando incremento de 11,2; 10,4 e 8,2\% nas camadas de 40-60, 60-80 e 80-100 cm, respectivamente. Dessa forma, a aplicação do gesso favoreceu o aumento no estoque de $\mathrm{CP}$, provavelmente associado ao maior fornecimento de biomassa radicular em profundidade pelo uso dessa tecnologia, conforme observado em outros trabalhos (Morelli et al., 1992; Penatti 2013). De maneira geral, a oferta de biomassa pelo sistema radicular de culturas perenes proporciona aumento do estoque de CP (Figueiredo et al., 2010; Ferreira, 2013).

$\mathrm{O}$ estoque de $\mathrm{CP}$ é o compartimento de maior sensibilidade às alterações provocadas no solo pelos sistemas de manejo agrícolas (Bayer et al., 2004; Loss et al., 2014; Pinheiro et al., 2015). No entanto, em sistemas que utilizam apenas culturas anuais os ganhos no estoque de $\mathrm{CP}$ na maior parte das vezes estão restritos às camadas superficiais do solo (Carmo et al., 2012; Briedis et al., 2012) associado a deposição da biomassa vegetal aérea e a concentração do sistema radicular na superfície do solo (0-20 
$\mathrm{cm})$. Portanto, manejos agrícolas que utilizam culturas perenes com abundante sistema radicular e adotam tecnologias que proporcionam a melhor distribuição das raízes podem favorecer o aumento do estoque de $\mathrm{CP}$ em camadas mais profundas $(40-100 \mathrm{~cm})$ em curtos períodos, conforme verificado nesse trabalho.

Dessa maneira, as raízes possuem papel fundamental no armazenamento de C em camadas mais profundas do solo, tanto pela menor taxa de mineralização dos tecidos radiculares quanto pela produção de exsudatos (Molina et al., 2001; Schmidt et al., 2011). Conforme observado por Kuzyakov \& Domanski (2000), 26\% e 17\% do C assimilado pelas culturas do trigo e cevada, respectivamente, foram translocados para as raízes, enquanto que para culturas perenes, de 30 a 50\%. Esse $\mathrm{C}$ translocado foi distribuído para o crescimento radicular, exudatos e respiração, onde parte desse C é incorporado ao solo. Essa importante contribuição das raízes no estoque de $\mathrm{C}$ do solo também está associada às baixas concentrações de $\mathrm{C}$ no subsolo e, consequentemente, com maior potencial de armazenar carbono em relação às camadas superficiais do solo (Rumpel \& Kögel-Knabner, 2011).

O CM é o compartimento de maior estabilidade da matéria orgânica do solo devido a sua presença em compostos com avançado estágio de humificação. Além disso, o CM apresenta forte interação com as frações argila e silte do solo, proteção física no interior dos microagregados, e maior recalcitrância química ocasionada pela decomposição (Bayer et al., 1996; Resck et al., 2008). Portanto, frequentemente não apresenta sensibilidade em curto prazo às alterações nas práticas de manejo do solo (Ferreira, 2013; Figueiredo 2010).

De forma geral, o estoque de CM constitui o estoque de carbono cujas alterações ocorrem à médio e longo prazo no solo (Salton et al., 2005). Nesse trabalho o uso do gesso não alterou os estoques de carbono associado aos minerais (CM) na camada de 0$40 \mathrm{~cm}$ (Figura 6.6c). No entanto, observou-se efeito significativo do gesso na camada de 40-100, com ganho de $3,7 \mathrm{Mg} \mathrm{ha}^{-1}$, que representa aumento de $6,8 \%$ no estoque de carbono nessa camada (Figura 6.6d).

Ainda considerando a camada de $40-100 \mathrm{~cm}$ o aumento no estoque de CM favorecido pelo uso do gesso representou $84,1 \%$ do incremento observado no estoque de CT. Dessa forma, apesar do curto período considerado (4 anos) o C incorporado ao solo favorecido pelo uso do gesso proporcionou o armazenamento de $\mathrm{C}$ no compartimento de maior estabilidade do solo. Assim, o incremento do estoque de CM representa a diminuição da emissão $\mathrm{CO}_{2}$ para a atmosfera, pois esse compartimento de 
C no solo possui maior tempo de reciclagem devido à lenta mineralização pela microbiota do solo em relação ao estoque de CP (Campos et al., 2011).

Frequentemente trabalhos que foram conduzidos por curtos períodos com culturas anuais e sistemas de manejo não encontraram incremento no estoque de CM (Carmo et al., 2012). No entanto, em culturas perenes tem sido observado ganhos nesse compartimento de maior estabilidade (Mancin et al., 2013), o que provavelmente está associado a maior produção de biomassa radicular pelas culturas perenes. Dessa forma, a cana-de-açúcar possui potencial de incrementar o estoque de CM e com maior eficiência quando associado com o gesso, em relação as culturas anuais.
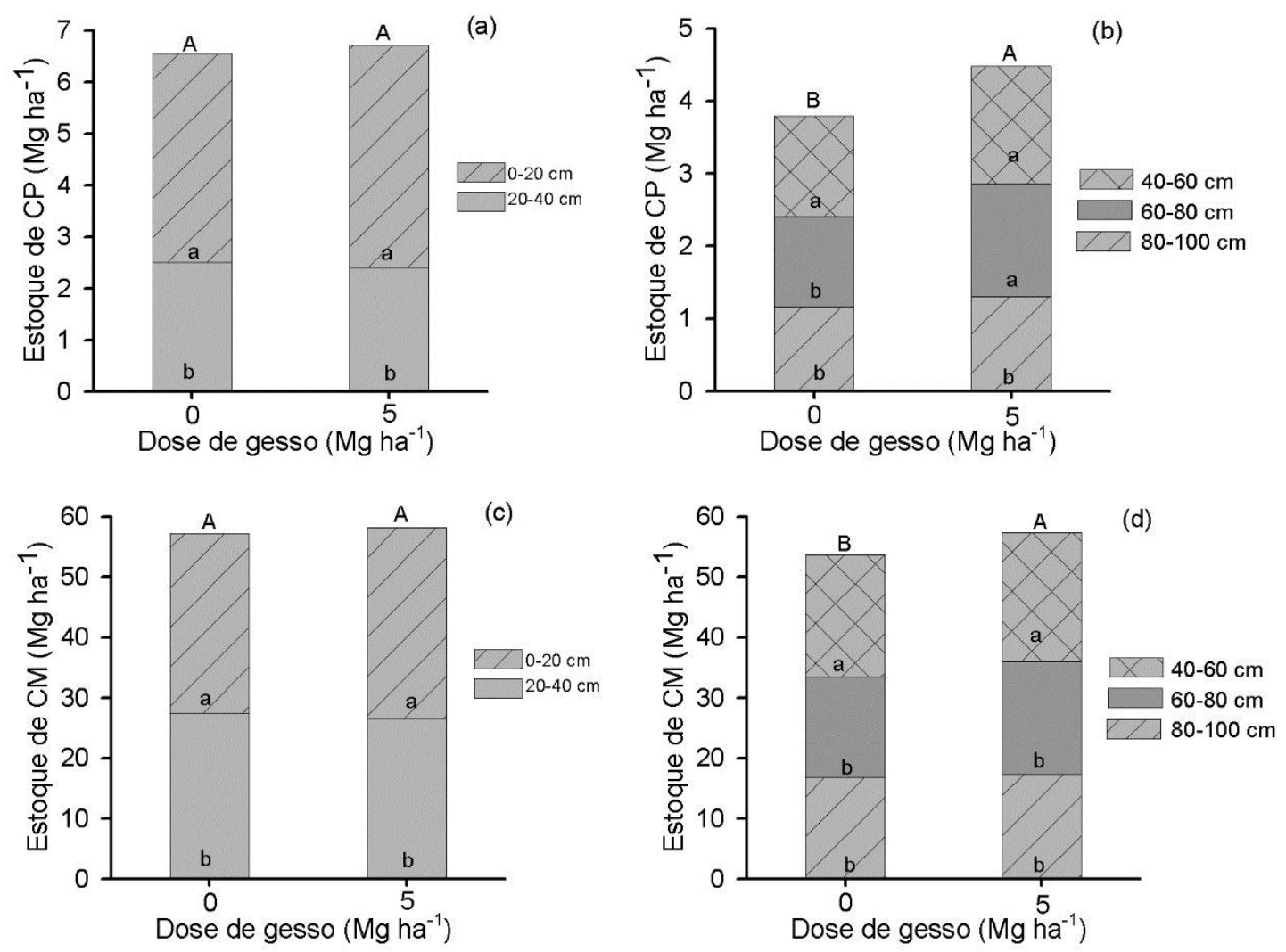

Figura 6.6: Estoque de carbono particulado (CP) nas camadas de $0-20$ e $20-40 \mathrm{~cm}$ (a) e 40-60, 60-80 e 80-100 cm (b) e estoque de carbono associado aos minerais (CM) nas camadas de 0-20 e 20-40 cm (c) e 40-60, 60-80 e 80-100 cm (d), após quatro cortes de cana-de-açúcar, cana planta e três socas, em resposta a doses de gesso aplicado no plantio. Tratamentos seguidos pela mesma letra maiúscula e profundidades pela mesma letra minúscula não diferem estatisticamente pelo teste $t(p<0,05)$. 
A quantidade de $\mathrm{C}$ da biomassa de palha produzida na terceira soca mais palhiço resultante da decomposição da palha deixada sob a superfície do solo da cana-planta, primeira e segunda soca que permaneceu na superfície do solo após quatro cortes de cana-de-açúcar foi de 8,0 e 9,6 $\mathrm{Mg} \mathrm{ha}^{-1}$, sem e com aplicação de do gesso, respectivamente, que significou um acréscimo de C de 20,0\% (Tabela 6.2). Quando somados o estoque de CT do solo (camada 0-100) ao C depositado na superfície do solo como palha, foram imobilizados 129,27 e $136,33 \mathrm{Mg} \mathrm{ha}^{-1}$ de $\mathrm{C}$, para os tratamentos com 0 e $5 \mathrm{Mg} \mathrm{ha}^{-1}$ de gesso, respectivamente. Com isso, 7,06 $\mathrm{Mg} \mathrm{ha}^{-1}$ de C (25,9 $\mathrm{Mg} \mathrm{ha}^{-1} \mathrm{de}$ $\mathrm{CO}_{2}$ em 4 anos) foram imobilizados a mais devido à aplicação de gesso, sendo 23,0\% na palha e 77,0\% no solo, evidenciando a importância dessa tecnologia no sequestro de C no solo.

Do total de $\mathrm{C}$ armazenado a mais no solo devido à aplicação do gesso, ou seja, 5,4 $\mathrm{Mg} \mathrm{ha}^{-1}, 20 \%$ permaneceu na camada de $0-40 \mathrm{~cm}$, enquanto $80 \%$ foi estocado na camada de 40-100 $\mathrm{cm}$. A maior quantidade de $\mathrm{C}$ armazenada em camadas mais profundas do solo acontece devido ao gesso favorecer o crescimento das raízes nessas camadas, propiciados pela melhoria das condições química do solo e, consequentemente, maior quantidade de $\mathrm{C}$ estocado no solo.

Tabela 6.2: Carbono armazenado pelo palhiço de cana-de-açúcar e no solo, sem e com aplicação de gesso, após 4 cortes.

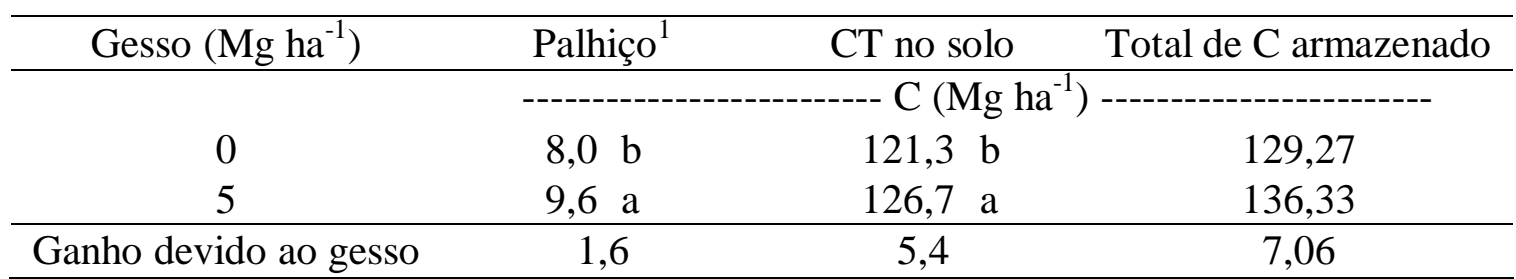

${ }^{1}$ Palha produzida na terceira soca mais palhiço resultante da decomposição de palha deixado sob a superfície do solo da cana-planta, primeira e segunda soca.

As camadas mais profundas do solo apresentam baixos teores de $\mathrm{C}$, que conferem maior capacidade de armazenar e proteger esse elemento, contribuindo assim para minimizar as concentrações de $\mathrm{CO}_{2}$ na atmosfera, reduzindo os danos dos gases do efeito estufa.

A taxa anual de $\mathrm{C}$ acumulado pela cultura da cana-de-açúcar na camada de 0$100 \mathrm{~cm}$ do solo em quatros anos que foi de 4,95 $\mathrm{Mg} \mathrm{ha}^{-1} \mathrm{ano}^{-1} \mathrm{de}_{\mathrm{CO}_{2}}$, devido ao uso do gesso, que pode ser comparada, por exemplo, com outra importante tecnologia no 
sequestro de C que é o sistema de plantio direto (SPD) em relação ao sistema de preparo convencional (SPC).

Boddey et al (2010), comparando SPD com SPC em experimentos conduzidos de 15 a 26 anos com sequência de cultivos anuais em rotação, observaram ganhos nas taxas anuais de C acumulado na camada de 0-100 cm do solo variando de 1,72 a 4,07

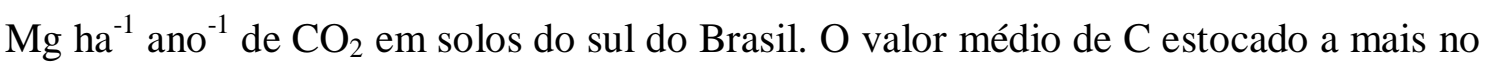
solo nesses experimentos devido ao SPD foi de 2,7 $\mathrm{Mg} \mathrm{ha}^{-1} \mathrm{ano}^{-1} \mathrm{de} \mathrm{CO}_{2}$, inferior ao observado na cana devido ao uso do gesso.

Portanto, o uso do gesso em cana-de-açúcar apresenta um potencial de sequestro de carbono similar ou superior ao observado com uso do SPD no sul do país com culturas anuais, sendo mais uma tecnologia disponível para colaborar na redução dos gases de efeito estufa.

\subsection{CONCLUSÕES}

1. O uso do gesso proporcionou incremento na produção acumulada de biomassa de colmos e de palha de 16,9 e $17,1 \%$, respectivamente, nos quatro cortes de cana-deaçúcar.

2. A aplicação de gesso elevou os teores de $\mathrm{CO}$ em 12,4; 12,2 e $12,1 \%$ nas camadas de 40-60; 60-80 e 80-100 cm, respectivamente.

3. O uso do gesso promoveu aumento de $5,4 \mathrm{Mg} \mathrm{ha}^{-1}$ no estoque de CT no solo na camada de 0-100 cm, sendo 4,4 $\mathrm{Mg} \mathrm{ha}^{-1}$ na camada de 40-100 cm.

4. O estoque de CP na camada de 40-100 cm aumentou em 18,4\% devido ao uso do gesso e representou $15,9 \%$ do incremento observado do estoque de CT, enquanto que o estoque de CM aumentou 6,8\% com aplicação de gesso, representando 84,1\% do acréscimo no estoque de CT.

5. Do incremento total obtido nos estoques de $\mathrm{C}$ devido ao uso do gesso, $80 \%$ ocorreram na camada de $40-100 \mathrm{~cm}$. 


\subsection{REFERÊNCIAS BIBLIOGRÁFICAS}

BAYER, C. Dinâmica da matéria orgânica em sistemas de manejo de solos. 1996. 241p. Tese (Doutorado) - Universidade Federal do Rio Grande do Sul, Porto Alegre, 1996.

BAYER, C.; MARTIN-NETO, L.; MIELNICZUK, J.; PAVINATO, A. Armazenamento de carbono em frações lábeis da matéria orgânica de um Latossolo Vermelho sob plantio direto. Pesquisa Agropecuária Brasileira, Viçosa, v.39, n.7, p.677-683, 2004.

BAYER, C.; MARTIN-NETO, L.; MIELNICZUK, J.; PAVINATO, A.; DIECKOW, J. Carbon sequestration in two Brazilian Cerrado soils under no-till. Soil and Tillage Research, 86:237-245, 2006.

BODDEY, R.M.; JANTALIA, C.P.; CONCEICAO, P.C.; ZANATTA, J.A.; BAYER, C.; MIELNICZUK, J.; DIECKOW, J.; SANTOS, H.; DENARDIN, J.E.; AITA, C.; GIACOMINI, S.J.; ALVES, B.J.R.; URQUIAGA, S. Carbon accumulation at depth in Ferralsols under zero-till subtropical agriculture. Global Change Biology, v.16, n.2, p.784-795, 2010.

BRIEDIS, C.; SÁ, J.C.D.M.; DE-CARLI, R.S.; ANTUNES, E.A.P.; SIMON, L.; ROMKO, M.L.; ELIAS, L.C.; FERREIRA, A.D.O. Particulate soil organic carbon and stratification ratio increases in response to crop residue decomposition under no-till. Revista Brasileira de Ciência do Solo, Viçosa, v.36, n.5, p.1483-1490, 2012.

CAMBARDELLA, C.A. \& ELLIOTT, E.T. Particulate soil organic-matter changes across a grassland cultivation sequence. Soil Science Society of America Journal, Madison, v.56, n.3, p.777-783, 1992.

CAMPOS, B.H.C.D.; AMADO,T.J.C.; BAYER, C.; NICOLOSO, R.D.S.; FIORIN, J.E. Carbon stock and its compartments in a subtropical oxisol under long-term tillage and crop rotation systems. Revista Brasileira de Ciência do Solo, v.35, n.3, p.805-817, 2011.

CARMO, F.F.; DE FIGUEIREDO, C.C.; RAMOS, M.L.G.; VIVALDI, L.J.; ARAÚJO, L.G. Frações granulométricas da matéria orgânica em latossolo sob plantio direto com gramíneas, Bioscience Journal, Uberlândia, v.28, n.3, 2012. 
CARVALHO, J.L.N.; OTTO, R.; FRANCO, H.C.J.; TRIVELIN, P.C.O. Input of sugarcane post-harvest residues into the soil. Scientia Agricola, Piracicaba, v.70, n.5, p. 336-344, 2013.

CERRI, C.C.; GALDOS, M.V.; MAIA, S.M.F.; BERNOUX, M.; FEIGL, B.J.; POWLSON, D.; CERRI, C.E. P. Effect of sugarcane harvesting systems on soil carbon stocks in Brazil: an examination of existing data. European Journal of Soil Science, Oxford, v.62, n.1, p.23-28, 2011.

CHOHFI, F.M.; DUPAS, F.A.; LORA, E.E.S. Balanço, Análise de Emissão e Seqüestro de CO2 na Geração de Eletricidade Excedente no Setor Sucro-Alcooleiro. In: Encontro de Energia no Meio Rural e Geração Distribuída, 5., 2004, Campinas, Anais... 8p.

COMPANHIA NACIONAL DE ABASTECIMENTO - CONAB. Séries Históricas Cana-de-açucar Relativas às Safras 2005/06 a 2014/15 de Área Plantada, Produtividade, Produção, Áçucar, Etanol total, Etanol anidro e Etanol hidratado. Disponível em: <http://www.conab.gov.br/conteudos.php?a=1252\&t=\&Pagina_objcmsconteudos=2\#A _objcmsconteudos >. Acesso em: 10 de Janeiro, 2015.

COMPANHIA NACIONAL DE ABASTECIMENTO - CONAB. Séries Históricas Milho Relativas às Safras 1976/77 a 2014/15 de Área, Produtividade, Produção. Disponível em: $<$ http://www.conab.gov.br/conteudos.php?a=1252\&\&Pagina_objcmsconteudos=3\#A_o bjcmsconteudos>. Acesso em: 29 de Janeiro, 2015.

COMPANHIA NACIONAL DE ABASTECIMENTO - CONAB. Séries Históricas Soja Relativas às Safras 1976/77 a 2014/15 de Área, Produtividade, Produção. Disponível em: $<\mathrm{http}: / /$ www.conab.gov.br/conteudos.php?a=1252\&t=\&Pagina_objcmsconteudos=3\#A _objcmsconteudos>. Acesso em: 29 de Janeiro, 2015.

CONSECANA. Conselho dos Produtores de Cana-de-Açúcar, Açúcar e Álcool do Estado de São Paulo. Manual de instruções. 5. ed. Piracicaba-SP, 2006. 111p.

COSTA, F. D. S.; BAYER, C.; ZANATTA, J. A.; MIELNICZUK, J. Estoque de carbono orgânico no solo e emissões de dióxido de carbono influenciadas por sistemas de manejo no sul do Brasil. Revista Brasileira de Ciência do Solo, Viçosa, v.32, n.1, p.323-332, 2008. 
ELLERT, B.H. \& BETTANY, J.R. Calculation of organic matter and nutrients stored in soils under contrasting management regimes. Canadian Journal of Soil Science, Ottawa, v.75, n.4, p.529-538, 1995.

EVANS, H., 1936. The root-system of the sugar-cane: II. Some typical root-systems. Empire Journal of Experimental Agriculture, Oxiford, v.4, p.208-221, 1936.

FERREIRA, E.A.B. Dinâmica de longo prazo do carbono do solo em sistemas de manejo no Cerrado. 2013. 233f. Tese (Doutorado em Ecologia) - Instituto de Ciências Biológicas, UnB, Brasília, 2013.

FIGUEIREDO, C.C.D., RESCK, D.V.S.; CARNEIRO, M.A.C. Labile and stable fractions of soil organic matter under management systems and native Cerrado. Revista Brasileira de Ciência do Solo, Viçosa, v.34, n.3, p.907-916, 2010.

GALDOS, M.V.; CERRI, C.C.; CERRI, C.E.P. Soil carbon stocks under burned and unburned sugarcane in Brazil. Geoderma. Soil carbon stocks under burned and unburned sugarcane in Brazil. Geoderma, Amsterdam, v.153, n.3, p.347-352, 2009.

KORNDÖRFER, G.H.; VIEIRA, G.G.; MARTINS, J.; MATHIESEN, L.A. Crescimento e distribuição do sistema radicular da cana-de-açúcar em solo LVA. Boletim Técnico Copersucar, n.47, p.32- 36, 1989.

KUZYAKOV, Y. \& DOMANSKI, G. Carbon input by plants into the soil. Review. Journal of Plant Nutrition and Soil Science, v.163, n.4, p.421-431, 2000.

LANDELL, M.G.A.; CAMPANA, M.P.; FIGUEIREDO, P.; VASCONCELOS, A.C.M.; XAVIER, M.A.; BIDOIA, M.A. P.; PRADO, H.; SILVA, M.A.; DINARDOMIRANDA, L.L.; SANTOS, A.S.; PERECIN, D.; ROSSETO, R.; SILVA, D.S.; MARTINS, A.L.M.; GALlO, P.B.; KANTHACK, R.A.D.; CAVICHIOLI, J.C.; VEIGA FILHO, A.A.; ANJOS, I.A.; AZANIA, C.A.M.; PINTO, L.R.; SOUZA, S.A.C.D. Variedades de cana-de-açúcar para o Centro-Sul do Brasil. Campinas: Instituto Agronômico. 2005. 33p. (Boletim Técnico, 197).

LOSS, A.; PEREIRA, M.G.; COSTA, E.M.; BEUTLER, S.J. Frações granulométricas e oxidáveis de matéria orgânica sob diferentes sistemas de uso do solo, no Paraná, Brasil. Bioscience Journal, Uberlândia, v.30, n.1, p.43-54, 2014.

LUCA, E.D.; FELLER, C., CERRI, C.C.; BARTHÈS, B.; CHAPLOT, V.; CAMPOS, D.C.; MANECHINI, C Avaliação de atributos físicos e estoques de carbono e 
nitrogênio em solos com queima e sem queima de canavial. Revista Brasileira de Ciência do Solo, Viçosa, v.32, n.02, p.789-800, 2008.

MACEDO, I.C.; SEABRA, J.E.A.; SILVA, J. Greenhouse gases emissions in the production and use of ethanol from sugarcane in Brazil: The 2005/2006 averages and a prediction for 2020. Biomass and bioenergy, Reino Unido, v.32, n.7, p.582-595, 2008. MACHADO, P.L.O.A. Soil carbon and the mitigation of global climate change. Química Nova, São Paulo, v.28, n.2, p. 329-334, 2005.

MAIA, C. L. A.; ASSAD, E.D.; FRANCHINI, J.C.; SA, J.C.M.; LANDERS, J.N.; AMADO, T.J.C.; RODRIGUES, R.A.R.; ROLOFF, G.; BLEY JUNIOR, C.; ALMEIDA, H.G.; MOZZER, G.B.; BALBINO, L.C.; GALERANI, P.R; EVANGELISTA, B.A.; PELLEGRINO, G.Q.; MENDES, T.A.; AMARAL, D.D.; RAMOS, E.; MELLO, I.; RALISCH, R,. O aquecimento global e a agricultura de baixa emissão de carbono. Brasília: MAPA / EMBRAPA / FEBRAPDP, 2011. 75p.

MANCIN, C.R.; SOUZA, L.C.F.; VITORINO, A.C.T.; PEREIRA, S.B.; ZANON, G.D.; SILVA, F.P.M. Organic matter in a dystroferric Red Latossol under no-tillage. Semina: Ciências Agrárias, Londrina, v.34, n.2, p.635-648, 2013.

MARSCHNER, H. Marschner's mineral nutrition of higher plants. 1.ed. P. Marschner Academic press, 2012.

Mc CARTY, G.W.; REEVES III, J.B.; YOST, R.; DORAISWAMY, P.C.; DOUMBIA, M. Evaluation of methods for measuring soil organic carbon in West African soils. African Journal of Agricultural Research, Lagos, v.5, n.16, p.2169-2177, 2010.

MELlO, F.F.; CERRI, C.E.; DAVIES, C.A.; HOLBROOK, N.M.; PAUSTIAN, K.; MAIA, S.M.; GALDOS, M.V.; BERNOUX; CERRI, C.C. Payback time for soil carbon and sugar-cane ethanol. Nature Climate Change, New York, v.4, n.7, p. 605-609, 2014.

Ministério da Ciência, Tecnologia e Inovação - MCTI. Estimativas anuais de emissões de gases de efeito estufa no Brasil 2013. Disponível em: < http://gvces.com.br/arquivos/177/EstimativasClima.pdf >. Acesso em: 04 de dezembro, 2014.

MOLINA, J.A.E.; CLAPP, C.E.; LINDEN, D.R.; ALLMARAS, R.R.; LAYESE, M.F.; DOWDY, R.H; CHENG, H.H. Modeling the incorporation of corn (Zea mays L.) 
carbon from roots and rhizodeposition into soil organic matter. Soil Biology and Biochemistry, Heidelberg, v.33, n.1, p.83-92, 2001.

MORELli, J.L.; DALBEN, A.E.; ALMEIDA, J.O.C.; DEMATTÊ, J.L. Calcário e gesso na produtividade da cana-de-açúcar e nas características químicas de um Latossolo de textura média álico. Revista Brasileira de Ciência do Solo, Viçosa, v.16, n.2, p.187-194, 1992.

NELSON, D.W. \& SOMMERS, L.E. Total carbon, organic carbon and organic matter. In: Methods of Soil Analysis Part 3. Chemical Methods-SSSA Book Series no 5. Madison: Soil Sciense Society of America and American Society of Agronomy, 1996. p.963-1010.

NEWMAN, A. Effect of sugarcane residue management on soil organic carbon in a louisiana agricultural system: implications for carbon sequestration. 2014. 63f. Dissertação. Agricultural and Mechanical College, LSU, Luisiana, 2014.

NUNES, R.S. de; LOPES, A.A.C. de; SOUSA, D.M.G. de; MENDES, I.C. de. Sistemas de manejo e os estoques de carbono e nitrogênio em Latossolo de Cerrado com a sucessão soja-milho. Revista Brasileira de Ciência do Solo, 35:1407-1419, 2011.

OTTO, R. Desenvolvimento radicular e produtividade da cana-de-açúcar relacionados à mineralização do $\mathbf{N}$ do solo e à adubação nitrogenada. 2012. 120f. Tese (Doutorado em Solos e Nutrição de Plantas) - Escola Superior de Agricultura Luiz de Queiroz, USP, Piracicaba, 2012.

PENATTI, P.C. Adubação da cana-de-açúcar: 30 anos de experiência. 1.ed. Itu: Ottoni, 2013. 347p.

PINHEIRO, E.F.M.; DE CAMPOS, D.V.B.; CARVALHO B.F.; ANJOS, L.H.C.; PEREIRA, M.G. Tillage systems effects on soil carbon stock and physical fractions of soil organic matter. Agricultural Systems, v.132, p.35-39, 2015.

RASSE, D.P.; RUMPEL, C.; DIGNAC, M.F. Is soil carbon mostly root carbon? Mechanisms for a specific stabilisation. Plant and soil, Dordrecht, v.269, n.1-2, p.341$356,2005$.

RESCK, D. V. S.; FERREIRA, E. A. B.; FIGUEIREDO, C. C.; ZINN, Y. L. Dinâmica da matéria orgânica no Cerrado. In: SANTOS, G. A.; SILVA, L. S.; CANELLAS, L. P.; 
CAMARGO, F. O. (Ed.). Fundamentos da matéria orgânica do solo: ecossistemas tropicais e subtropicais. 2. ed. Porto Alegre: Metrópole, 2008. p.359-417.

ROCHA, A.T.; OLIVEIRA, A.C.; RODRIGUES, Á.N.; LIRA JÚNIOR, M.A.; FREIRE, F.J. Emprego do gesso do Araripe na melhoria do ambiente radicular da canade-açúcar. Revista Brasileira de Ciências Agrárias, Pernambuco, v.3, n.4, p.307-312, 2008.

ROSSETTO, R.; VITTI, A.C.; GAVA, G.L.C; MELLIS, E.V.; VARGAS, V.P.; CANTARELLA, H.;PRADO, H.; DIAS, F.L.F.; LANDELL, M.G.A.; BRANCALIÃO, S.R.; GARCIA, J.C. Cana-de-açúcar - Cultivo com sustentabilidade, n. 142. International plant nutrition institute, Piracicaba, 2013. 13 p. Informações Agronômicas. RUMPEL, C. \& KÖGEL-KNABNER, I. Deep soil organic matter-a key but poorly understood component of terrestrial C cycle. Plant and Soil, Dordrecht, v.338, n.1-2, p.143-158, 2011.

SANTOS, F.A.; QUEIRÓZ, J.D.; COLODETTE, J.L.; FERNANDES, S.A.; GUIMARÃES, V.M.; REZENDE, S.T. Potencial da palha de cana-de-açúcar para produção de etanol. Química Nova, São Paulo, v.35, n.5, p.1004-1010, 2012.

SANTOS, R.L.; FREIRE, F.J.; AZEVEDO, V.M.; ROCHA, A.T.; TAVARES, J.A. Produção de capim elefante e movimentação de cátions em função de gesso mineral. Revista Brasileira de Engenharia Agrícola e Ambiental, Campina Grande, v.17, n.10, p.1030-1037, 2013.

SATO, J.H.; FIGUEIREDO, C.C.; MARCHÃO, R.L.; MADARI, B.E.; BENEDITO, L.E.C.; BUSATO, J.G.; SOUZA, D.M.D. Methods of soil organic carbon determination in Brazilian savannah soils. Scientia Agricola, Piracicaba, v.71, n.4, p.302-308, 2014.

SCHMIDT, M.W.; TORN, M.S.; ABIVEN, S.; DITTMAR, T.; GUGGENBERGER, G.; JANSSENS, I.A.; KLEBER, M.; KNABNER, I.K.; LEHMANN, J.; MANNING, D.A.C.; NANNIPIERI, P.; RASSE, D.P.; WEINER, S.; TRUMBORE, S.E. Persistence of soil organic matter as an ecosystem property. Nature, New York, v.478, n.7367, p.49-56, 2011.

SEGNINI, A.; SANTOS, L.M.D.; SILVA, W.T.L.D.; MARTIN-NETO, L.; BORATO, C.E.; MELO, W.J.D.; BOLONHEZI, D. Comparative study of carbon quantification 
methods in soil with high Fe contents (Oxisols). Química Nova, São Paulo, v.31, n.1, p.94-97, 2008.

SMITH, J.P.; LAWN, R.J.; NABLE, R.O. Investigations into the root: shoot relationship of sugarcane, and some implications for crop productivity in the presence of sub-optimal soil conditions. In: Proceedings of the Australian Society of Sugarcane Technologists. Australian Society of Sugarcane Technologists, 1999. p. 108-113.

SMITH, D.M.; INMAN-BAMBER, N.G.; THORBURN, P.J. Growth and function of the sugarcane root system. Field Crops Research, v.92, n. 2, p.169-183, 2005.

SOUSA, D.M.G.; REIN, T.R.; LOBATO, E.; RITCHEY, K.D. Sugestões para a diagnose e recomendação de gesso em solos de Cerrado. In: SEMINÁRIO SOBRE O USO DO GESSO NA AGRICULTURA, 2. 1992, Uberaba. Resumos... p. 139-158.

SOUZA, Z.M., MELLO P.R., PAIXÃO, A.C.S.; CESARIN, L.G. Sistemas de colheita e manejo da palhada de cana-de-açúcar. Pesquisa Agropecuária Brasileira, Brasília, v.40, n.3, p.271-278, 2005.

VITTI, A.C.; TRIVELIN, P.C.O.; CANTARELLA, H.; FRANCO, H.C.J.; FARONI, C.E.; OTTO, R.; TRIVELIN, M.O.; TOVAJAR, J.G. Mineralização da palhada e crescimento de raízes de cana-de-açúcar relacionados com a adubação nitrogenada de plantio. Revista Brasileira de Ciência do Solo, Viçosa, v.32, p. 2757-2762, 2008.

WALKLEY, A. \& BLACK, I. A. An examination of Degtjareff method for determining soil organic matter, and proposed modification of the chromic acid tritation method. Soil Science, Baltimore, v.75, p.37:29-38, 1934.

YOUKHANA, A.H.; CROW' S.; KINIRY, J.R.; MEKI, M.; OGOSHI, R.M.; NAKHATA, M. Above and Belowground Biomass Dynamics Under Ratoon Harvest Practices for Biofuel Feedstock Production in Hawaii. In: INTERNATIONAL ANNUAL MEETING GRAND CHALLENGES GREAT SOLUTIONS. 2014, Long beach. Resumos... p.227. 
Anexo 1- Temperatura máxima, mínima e média* considerando os decêndios do período de julho/2009 a agosto/2013 da cana planta (a), primeira soca (b), segunda soca (c) e terceira soca (d).
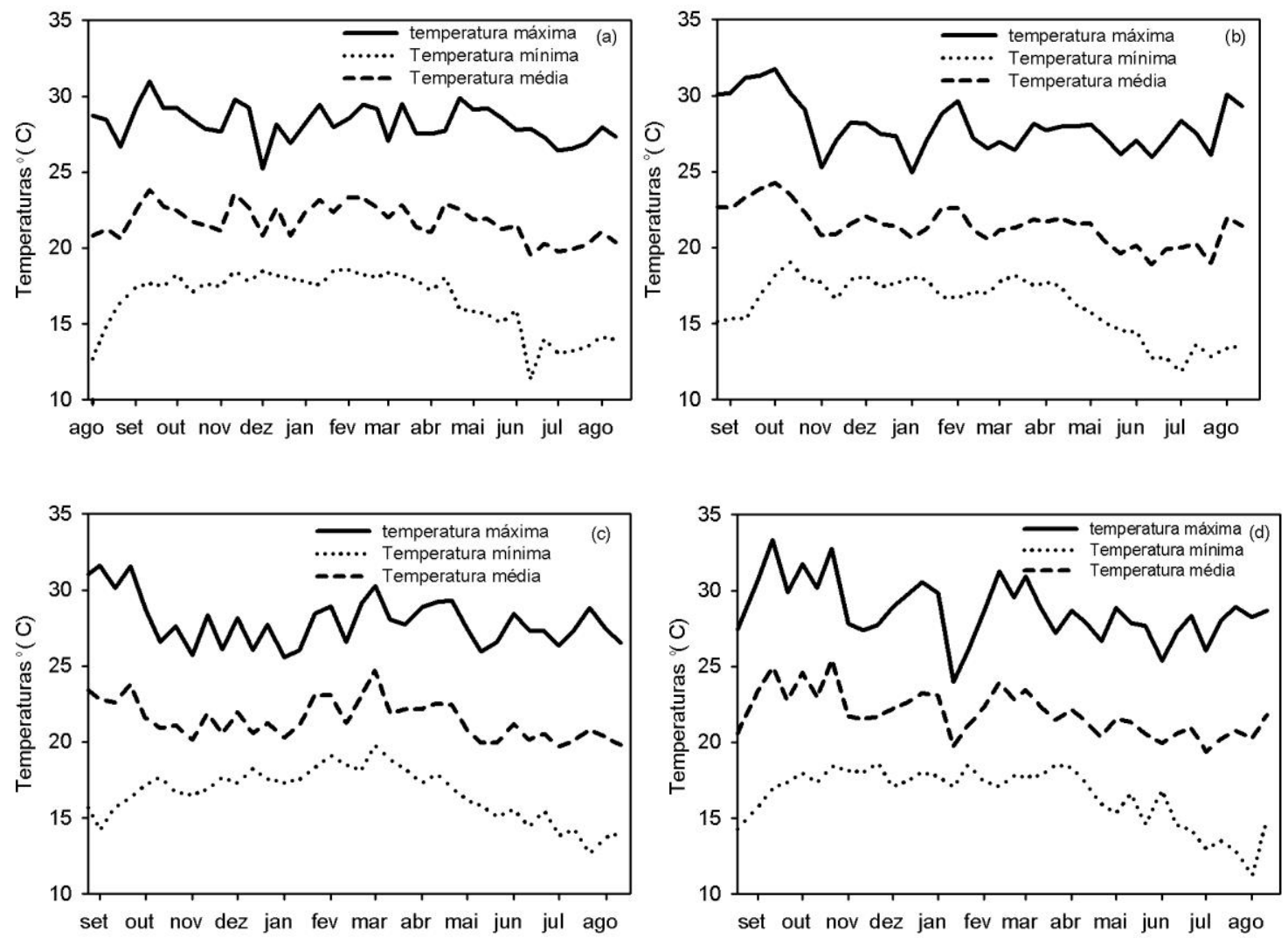

*Estação meteorológica da Embrapa Cerrados. 
Anexo 2: Características Agronômicas - Variedade RB 867515 (Genitores: (RB72454)

Características agronômicas da variedade RB 867515 (Fonte: Hoffmann, H.P.; Santos, E.G.D.; Bassinello, A.I.V.; Vieira, M.A.S. Variedades RB de Cana-de-açúcar, UFSCar, p.30, 2008).

\begin{tabular}{|c|c|c|}
\hline \multicolumn{2}{|c|}{ Características } & RB 867515 \\
\hline \multirow{2}{*}{\multicolumn{2}{|c|}{$\begin{array}{c}\text { Prod. Agrícola } \\
\text { Colheita }\end{array}$}} & Alta \\
\hline & & $\mathrm{Jul} / \mathrm{Set}$ \\
\hline \multirow{4}{*}{$\begin{array}{c}\text { Brot. } \\
\text { Soca } \\
\text { Perfilham. }\end{array}$} & Man. Queimada & Boa \\
\hline & Man. Crua & Boa \\
\hline & Cana planta & Baixo \\
\hline & Cana soca & Médio \\
\hline \multicolumn{2}{|c|}{ Fechamento } & Bom \\
\hline \multicolumn{2}{|c|}{ Tombamento } & Eventual \\
\hline \multicolumn{2}{|c|}{ Florescimento } & Eventual \\
\hline \multicolumn{2}{|c|}{ Chochamento } & Médio \\
\hline \multicolumn{2}{|c|}{ PUI } & Longo \\
\hline \multicolumn{2}{|c|}{ Exigência em ambientes } & Baixa \\
\hline \multicolumn{2}{|c|}{ Teor de sacarose } & Alto \\
\hline \multicolumn{2}{|c|}{ Teor de fibra } & Médio \\
\hline \multicolumn{2}{|c|}{ Carvão } & Resistente \\
\hline \multicolumn{2}{|c|}{ Ferrugem } & Resistente \\
\hline \multicolumn{2}{|c|}{ Escaldadura } & Resistente \\
\hline \multicolumn{2}{|c|}{ Mosaico } & Resistente \\
\hline \multicolumn{2}{|c|}{ Estrias vermelhas } & Intermediária \\
\hline \multicolumn{2}{|c|}{ Falsa est. vermelha } & Intermediária \\
\hline
\end{tabular}

- Aspectos Gerais:

Alta velocidade de crescimento, porte alto, hábito de crescimento ereto, alta densidade de colmo, de cor verde arroxeado que se acentua quando expostos e fácil despalha.

- Recomendações de Manejo: 
Não deve ser plantada em ambientes favoráveis devido à incidência de estrias

vermelhas. Nos ambientes de alto potencial de produção há possibilidades, devido à alta produtividade agrícola, de tombamento e atraso de maturação.

- Destaques:

Tolerante à seca e boa brotação de soqueira, mesmo colhida crua; alto teor de sacarose, crescimento rápido com alta produtividade. 